University of South Florida

DIGITAL COMMONS

Digital Commons @ University of

@ UNIVERSITY OF SOUTH FLORIDA

South Florida

Marine Science Faculty Publications

College of Marine Science

2020

\title{
Understanding of Contemporary Regional Sea-Level Change and the Implications for the Future
}

\author{
Benjamin D. Hamlington \\ California Institute of Technology \\ Alex S. Gardner \\ California Institute of Technology \\ Erik Ivins \\ California Institute of Technology \\ Jan T. Lenaerts

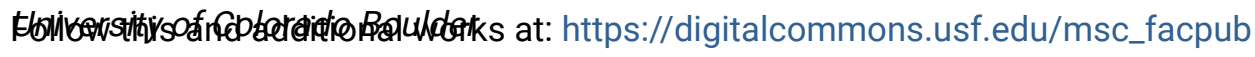

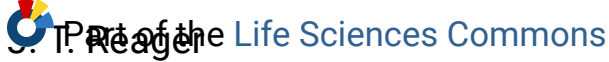 \\ California Institute of Technology
}

\section{Scholar Commons Citation}

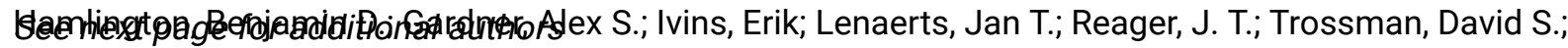
Zaron, Edward D.; Adhikari, Surendra; Arendt, Anthony; Aschwanden, Andy; Beckley, Brian D.; Bekaert, David P.; Blewitt, Geoffrey; Caron, Lambert; Chambers, Don P.; Chandanpurkar, Hrishikesh A.; Christianson, Knut; Csatho, Beata; Cullather, Richard I.; DeConto, Robert M.; Fasullo, John T.; Frederikse, Thomas; Freymueller, Jeffrey T.; Gilford, Daniel M.; Girotto, Manuela; Hammond, William C.; Hock, Regine; Holschuh, Nicholas; Kopp, Robert E.; Landerer, Felix; Larour, Eric; Menemenlis, Dimitris; Merrifield, Mark; Mitrovica, Jerry X.; Nerem, R. Steven; Nias, Isabel J.; Nieves, Veronica; Nowicki, Sophie; Pangaluru, Kishore; Piecuch, Christopher G.; Ray, Richard D.; Rounce, David R.; Schlegel, Nicole-Jeanne; Seroussi, Hélène; Shirzaei, Manoochehr; Sweet, William V.; Velicogna, Isabella; Vinogradova, Nadya; Wahl, Thomas; Wiese, David N.; and Willis, Michael J., "Understanding of Contemporary Regional Sea-Level Change and the Implications for the Future" (2020). Marine Science Faculty Publications. 1375.

https://digitalcommons.usf.edu/msc_facpub/1375

This Article is brought to you for free and open access by the College of Marine Science at Digital Commons @ University of South Florida. It has been accepted for inclusion in Marine Science Faculty Publications by an authorized administrator of Digital Commons @ University of South Florida. For more information, please contact digitalcommons@usf.edu. 


\section{Authors}

Benjamin D. Hamlington, Alex S. Gardner, Erik Ivins, Jan T. Lenaerts, J. T. Reager, David S. Trossman, Edward D. Zaron, Surendra Adhikari, Anthony Arendt, Andy Aschwanden, Brian D. Beckley, David P. Bekaert, Geoffrey Blewitt, Lambert Caron, Don P. Chambers, Hrishikesh A. Chandanpurkar, Knut Christianson, Beata Csatho, Richard I. Cullather, Robert M. DeConto, John T. Fasullo, Thomas Frederikse, Jeffrey T. Freymueller, Daniel M. Gilford, Manuela Girotto, William C. Hammond, Regine Hock, Nicholas Holschuh, Robert E. Kopp, Felix Landerer, Eric Larour, Dimitris Menemenlis, Mark Merrifield, Jerry X. Mitrovica, R. Steven Nerem, Isabel J. Nias, Veronica Nieves, Sophie Nowicki, Kishore Pangaluru, Christopher G. Piecuch, Richard D. Ray, David R. Rounce, Nicole-Jeanne Schlegel, Hélène Seroussi, Manoochehr Shirzaei, William V. Sweet, Isabella Velicogna, Nadya Vinogradova, Thomas Wahl, David N. Wiese, and Michael J. Willis 


\section{Reviews of Geophysics}

\author{
REVIEW ARTICLE \\ 10.1029/2019RG000672 \\ Key Points: \\ - An overview of the current state of \\ understanding of the processes that \\ cause regional sea-level change is \\ provided \\ - Areas where the lack of \\ understanding or gaps in knowledge \\ inhibit the ability to assess future \\ sea-level change are discussed \\ - The role of the expanded sea-level \\ observation network in improving \\ our understanding of sea-level \\ change is highlighted
}

Correspondence to: B. D. Hamlington,

bhamling@jpl.nasa.gov

\section{Citation:}

Hamlington, B. D., Gardner, A. S., Ivins, E., Lenaerts, J. T. M., Reager, J. T. Trossman, D. S., et al. (2020). Understanding of contemporary regional sea-level change and the implications for the future. Reviews of Geophysics, 58, e2019RG000672. https://doi.org/10.1029/2019RG000672

Received 1 OCT 2019 Accepted 19 MAR 2020 Accepted article online 17 APR 2020

(C)2020. American Geophysical Union. All Rights Reserved.

\section{Understanding of Contemporary Regional Sea-Level Change and the Implications for the Future}

\author{
Benjamin D. Hamlington ${ }^{1}$ (D), Alex S. Gardner ${ }^{1}$ (D), Erik Ivins ${ }^{1}$ iD, Jan T. M. Lenaerts ${ }^{2}$ iD,
} J. T. Reager ${ }^{1}$ (D), David S. Trossman ${ }^{3}$, Edward D. Zaron ${ }^{4}$ iD, Surendra Adhikari ${ }^{1}$ (D), Anthony Arendt $^{5}$ (D), Andy Aschwanden ${ }^{6}$ iD, Brian D. Beckley ${ }^{7}$, David P. S. Bekaert ${ }^{1}$ iD, Geoffrey Blewitt $^{8}$ (D), Lambert Caron ${ }^{1}$ (D), Don P. Chambers ${ }^{9}$ (D), Hrishikesh A. Chandanpurkar ${ }^{1}$ iD, Knut Christianson ${ }^{10}$ (D), Beata Csatho ${ }^{11}$, Richard I. Cullather ${ }^{12}$ (D), Robert M. DeConto ${ }^{13}$ (D), John T. Fasullo ${ }^{14}$ (iD, Thomas Frederikse ${ }^{1}$ (D), Jeffrey T. Freymueller ${ }^{15}$ iD, Daniel M. Gilford ${ }^{16}$ iD, Manuela Girotto ${ }^{17}$ iD, William C. Hammond ${ }^{8}$ iD, Regine Hock ${ }^{18}$ iD, Nicholas Holschuh ${ }^{10}$ (D), Robert E. Kopp ${ }^{17}$ (D), Felix Landerer ${ }^{1}$ (D), Eric Larour ${ }^{1}$ (D), Dimitris Menemenlis ${ }^{1}$ (D), Mark Merrifield ${ }^{19}$ (iD, Jerry X. Mitrovica ${ }^{20}$, R. Steven Nerem ${ }^{21}$ iD, Isabel J. Nias ${ }^{12,21}$ iD, Veronica Nieves $^{22}$ (D), Sophie Nowicki $^{21}$ iD, Kishore Pangaluru ${ }^{23}$, Christopher G. Piecuch ${ }^{24}$ (D), Richard D. Ray ${ }^{21}$ (D), David R. Rounce $^{18}$ iD, Nicole-Jeanne Schlegel ${ }^{1}$ iD, Hélène Seroussi ${ }^{1}$ iD, Manoochehr Shirzaei ${ }^{25}$ (D), William V. Sweet ${ }^{26}$, Isabella Velicogna ${ }^{22}$ (D), Nadya Vinogradova ${ }^{27}$, Thomas Wahl ${ }^{28}$ (iD, David N. Wiese ${ }^{1}$ (D) and Michael J. Willis ${ }^{29}$ (iD)

\begin{abstract}
${ }^{1}$ Jet Propulsion Laboratory, California Institute of Technology, Pasadena, CA, USA, ${ }^{2}$ Department of Atmospheric and Oceanic Sciences, University of Colorado Boulder, Boulder, CO, USA, ${ }^{3}$ Oden Institute for Computational Engineering and Sciences, University of Texas at Austin, Austin, TX, USA, ${ }^{4}$ Department of Civil and Environmental Engineering, Portland State University, Portland, OR, USA, ${ }^{5}$ Applied Physics Laboratory, University of Washington, Seattle, WA, USA, ${ }^{6}$ Geophysical Institute, University of Alaska Fairbanks, Fairbanks, AK, USA, ${ }^{7}$ KBR Inc., NASA Goddard Space Flight Center, Houston, TX, USA, ${ }^{8}$ Nevada Bureau of Mines and Geology, University of Nevada, Reno, NV, USA, ${ }^{9}$ College of Marine Science, University of South Florida, St. Petersburg, FL, USA, ${ }^{10}$ Department of Earth and Space Sciences, University of Washington, Seattle, WA, USA, ${ }^{11}$ Department of Earth Sciences, University of Buffalo, Buffalo, NY, USA, ${ }^{12}$ Earth System Science Interdisciplinary Center, University of Maryland, College Park, MD, USA, ${ }^{13}$ Department of Geosciences, University of Massachusetts Amherst, Amherst, MA, USA, ${ }^{14}$ National Center for Atmospheric Research, Boulder, CO, USA, ${ }^{15}$ Department of Earth and Environmental Sciences, Michigan State University, East Lansing, MI, USA, ${ }^{16}$ Institute of Earth, Ocean, and Atmospheric Sciences, Rutgers University, New Brunswick, NJ, USA, ${ }^{17}$ Department of Environmental Science and Policy Management, University of California, Berkeley, Berkeley, CA, USA, ${ }^{18}$ Geophysical Institute, University of Alaska Fairbanks, College, AK, USA, ${ }^{19}$ Scripps Institution of Oceanography, University of California, San Diego, La Jolla, CA, USA, ${ }^{20}$ Department of Earth and Planetary Sciences, Harvard University, Cambridge, MA, USA, ${ }^{21}$ CIRES and CCAR, University of Colorado Boulder, Boulder, CO, USA, ${ }^{22}$ Department of Physical Oceanography, Institute of Marine Sciences, Barcelona, Spain, ${ }^{23}$ Earth System Science, University of California, Irvine, Irvine, CA, USA, ${ }^{24}$ Physical Oceanography Department, Woods Hole Oceanographic Institution, Woods Hole, MA, USA, ${ }^{25}$ School of Earth and Space Exploration, Arizona State University, Tempe, AZ, USA, ${ }^{26}$ Center for Operational Oceanographic Products and Services, NOAA, Silver Spring, MD, USA, ${ }^{27}$ Science Mission Directorate, NASA Headquarters, Washington, DC, USA, ${ }^{28}$ Civil, Environmental and Construction Engineering and National Center for Integrated Coastal Research, University of Central Florida, Orlando, FL, USA, ${ }^{29}$ CIRES, University of Colorado Boulder, Boulder, CO, USA
\end{abstract}


understanding of these processes. Areas where the lack of understanding or gaps in knowledge inhibit the ability to provide the needed information for comprehensive planning efforts are of particular focus. Finally, a goal of this paper is to highlight the role of the expanded sea-level observation network - particularly as related to satellite observations-in the improved scientific understanding of the contributors to regional sea-level change.

Plain Language Summary This review paper addresses three important questions: (1) What do we currently know about the processes contributing to sea level change? (2) What observations do we use to gain this knowledge? and (3) Where are these gaps in our knowledge and the need for further improvement in our understanding of the drivers of regional sea level? By answering these specific questions in a focused manner, this paper should be a useful resource for other scientists, sea-level stakeholders, and a broader audience of those interested in sea level and our changing climate.

\section{Introduction}

Global mean sea level (GMSL) is an important indicator of a warming climate (Church \& White, 2011; Milne et al., 2009; Stammer et al., 2013), but changes in regional sea level are most relevant to coastal communities around the world (Kopp et al., 2015; Nicholls, 2011; Woodworth et al., 2019). The regional variability of the processes driving sea-level change (SLC), along with their uncertainties and relative importance over different time scales, pose challenges to planning efforts. Available observations of sea level show clear spatial and temporal inhomogeneity. From satellite altimeter observations covering the time period from 1993 to present, regional rates of rise can be more than double the global average in some locations while near zero at other locations (Cazenave \& Llovel, 2010). Furthermore, as a result of internal variability, the pattern of linear trends in regional sea level has shifted or reversed in many regions from the first half of the altimeter record to the second (e.g., Han et al., 2017; Peyser et al., 2016; Figure 1). Over longer time periods (i.e., hundreds of years), tide gauge records also show regional differences in the rates of SLC, owing in part to the vertical motion of the land upon which the gauges sit (e.g., Church et al., 2004; Church \& White, 2006; Hay et al., 2015; Kleinherenbrink et al., 2018; Santamaría-Gómez et al., 2014, 2017; Thompson et al., 2016). Understanding and accounting for these regional differences are critical first steps in providing information that is useful for planning efforts at the coast.

Due in large part to improvements in the sea-level observing system, the processes contributing to recent SLC are now well known. The uncertainty in the budget of GMSL rise over the last decade has been reduced (Cazenave et al., 2018), allowing for an assessment of the relative contributions of different processes that are important on global scales. While more challenging on regional levels, satellite observations, along with in situ measurements, have also led to a dramatically improved understanding of the processes causing regional differences in SLC. Fundamentally, the drivers that dominantly impact GMSL have a regional signature, and no process will result in a change that is uniform across the ocean (Milne et al., 2009; Stammer et al., 2013). Similarly, no contributor to SLC is constant in time, and the time scales upon which the processes vary can differ dramatically. Separating the contributors temporally and geographically can be useful when considering a particular planning horizon, although the range of variability inherent to the individual contributors can make this difficult. Additionally, it is the combined impact of several factors operating on these different scales that is of direct importance.

The causes of global and regional SLC have been the focus of recent review papers, with regional change most comprehensively discussed and summarized in Stammer et al. (2013), Kopp et al. (2015), and Slangen et al. (2017). The understanding of these processes has progressed in recent years, and the outstanding gaps in knowledge and remaining uncertainties have shifted accordingly. The intent of the present paper is to provide an overview and update of the current state of understanding of the processes that cause regional SLC and to identify and discuss limitations and uncertainty in our understanding of these processes. Although the focus is on contemporary SLC, we do include discussion of projections of future SLC. In particular, we are concerned with areas where lack of understanding or gaps in knowledge inhibit comprehensive planning efforts at the regional level. While we do not make explicit connections to planning efforts, we expect that a detailed discussion of uncertainties could be useful to those translating science into actionable plans (e.g., Horton et al., 2018). This paper is a resource for those interested in particular aspects of regional 

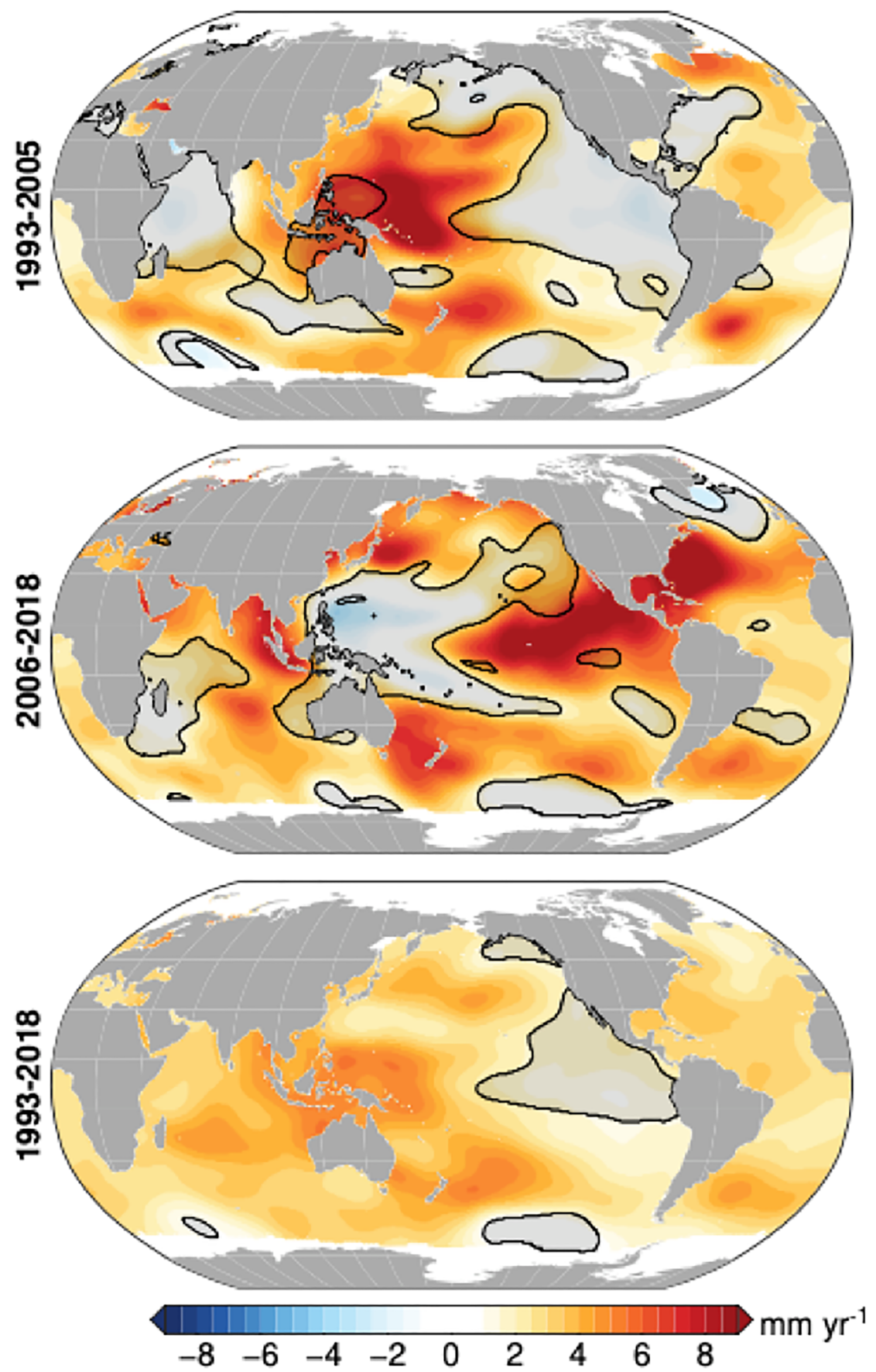

Figure 1. Satellite altimeter-measured regional sea-level trend patterns from (top) 1993-2005, (middle) 2006-2018, and (bottom) 1993-2018. Black contours and gray shading denote areas where the estimated trend is not significant at the 95\% confidence level.

SLC by giving a detailed presentation of the most recent estimates of their contributions and a discussion of where improvement may be made in the coming years. Finally, a goal of this paper is to highlight the potential role of the expanded sea-level observation network-particularly as related to satellites-to understanding the contributors to regional SLC.

This paper is organized according to the individual processes of regional relative SLC, with each process covered in a section. In section 2, we provide a brief summary of how the contributors to regional sea level are separated and we present definitions for the terminology adopted in the remainder of the paper. Sections 3 
through 8 discuss the individual processes contributing to regional SLC, with each section broken into two components: (1) a summary of the current state of knowledge, and (2) an overview of current limitations or areas of uncertainty and a discussion of where progress will likely be made in the coming years. In section 9 , we summarize advances toward overcoming these limitations or reducing uncertainties that may be expected through recent and future additions to the sea-level observational network, with particular emphasis on satellite-based observations.

\section{Processes Contributing to Regional SLC}

As we discuss in the sections to follow, changes in sea level arise from a diverse set of physical processes. As a result, scientists from a range of disciplines are working on different questions related to sea level. The need to address the impacts of ongoing and future SLC, along with associated policy considerations, further increases the breadth of those studying or interested in SLC. This diversity and broad interest have led to inconsistency in sea-level terminology that can hinder progress in research, communication, and policy. To address this issue, Gregory et al. (2019) have provided guidelines and clearly defined terminology for discussing SLC. In Gregory et al. (2019), SLC refers to the geocentric SLC, specifically the change in the height of sea level with respect to the terrestrial reference frame. When including the movement of the land at the coast, the phrase relative SLC is used, which is the change in the height of the mean sea surface relative to the solid surface, and thus includes the effects of vertical land motion (VLM). Given that relative SLC encompasses both geocentric SLC and VLM, and to simplify the discussion in this paper, we have chosen to use SLC to refer to changes in relative sea level for the remainder of this paper. The definition of spatial scales is separated by regional and global. The term "regional" is used to refer to processes that are considered properties of regions, with spatial of hundreds of kilometers and less. Unless specified, this includes local changes that occur at a specific geographic location. Processes are said to be of "global" scale if they contribute to variability in GMSL. The global mean refers specifically to the area-weighted mean of SLC for the entire connected surface of the ocean.

There are several ways to separate and distinguish between the different processes contributing to regional SLC. Here, we separate the contributors into six different sections. Regional and global SLC associated with ice mass changes is divided into contributions from ice sheets (section 3) and contributions from glaciers (section 4), recognizing that the observational and measurement considerations can differ between the two. Further changes arising from variability in land water storage are presented in a separate section (section 5). Each of these three contributors are discussed first in terms of their impact on GMSL, and then in terms of their regional signature through changes in Earth Gravitation, Rotation, and Deformation (GRD), caused by redistributions of land ice and water (discussed in more detail below). The primary intent of this paper is to discuss regional SLC, but the magnitude of the regional contributions of these factors is related to the size of their GMSL contribution. These three contributors are also intentionally covered first due to the similarity of the mechanism that impacts regional SLC. Regional SLC associated with steric variability and ocean dynamics (also referred to as sterodynamic SLC) is combined into a single discussion (section 6), which includes both natural and anthropogenic contributions. This section also covers dynamic SLC that may occur as a result of freshwater input into the ocean associated with the contributors in sections 3 through 5. Given its large contribution to the SLC at the coast, a section is included on VLM, covering a range of temporal and spatial scales (section 7). Finally, as the goal here is to cover a wide range of time scales that impact regional and local SLC, a section on higher-frequency variability is provided that includes variations in sea level associated with astronomic tides, storm surges, ocean swell, wave setup, and wave run-up (section 8).

We use the term sea level in this paper to refer to both the lower-frequency variations described in sections 3 through 6, and the higher-frequency variations in section 8. Pugh and Woodworth (2014) define sea level as the sum of four main components: mean sea level, astronomical tides, a meteorological component, and waves. Using this description, sections 3 through 6 largely discuss changes in mean sea level, while section 8 covers the other higher-frequency components. As a summary of the contributing factors covered in this paper, Table 1 provides an overview of the relevant time scales of each process in addition to the magnitude of its associated contribution on a yearly basis. One of the main takeaways from this breakdown is the wide range of time scales and subcomponents associated with each factor, and the degree to which each needs to be accounted for within any particular time frame of interest. 
Table 1

Components of Regional Sea-Level Rise Covered in This Paper, Along With Their Relevant Time Scales and Potential Magnitude

\begin{tabular}{lll}
\hline Component & Dominant temporal scales & Potential magnitude (yearly) \\
\hline Ice sheets & years to centuries & millimeters to centimeters \\
Glaciers (outside of ice sheets) & months to centuries & millimeters to centimeters \\
Steric and dynamic sea-level change & months to decades & millimeters to meters \\
Land water storage & months to decades & millimeters to centimeters \\
High-frequency water level variability & minutes to years & centimeters to meters \\
Solid earth deformation/vertical land motion & years to centuries & millimeters to meters \\
\hline
\end{tabular}

\section{Contributions From Ice Sheets}

\subsection{Current State of Knowledge}

Using measurements from the joint NASA (US) /DLR (Germany) Gravity Recovery and Climate Experiment (GRACE) twin satellite mission, the Greenland and Antarctic Ice Sheets lost mass and collectively contributed around $1.17 \pm 0.17 \mathrm{~mm} \mathrm{yr}^{-1}$ to GMSL (Figure 2) from 2002 to 2017, about one third of the total GMSL rise (Dieng et al., 2017). This rate has been steadily increasing since the 1990s (Bamber et al., 2018). The Greenland Ice Sheet holds enough water to raise GMSL by $7.4 \mathrm{~m}$, while the Antarctic Ice Sheet has the
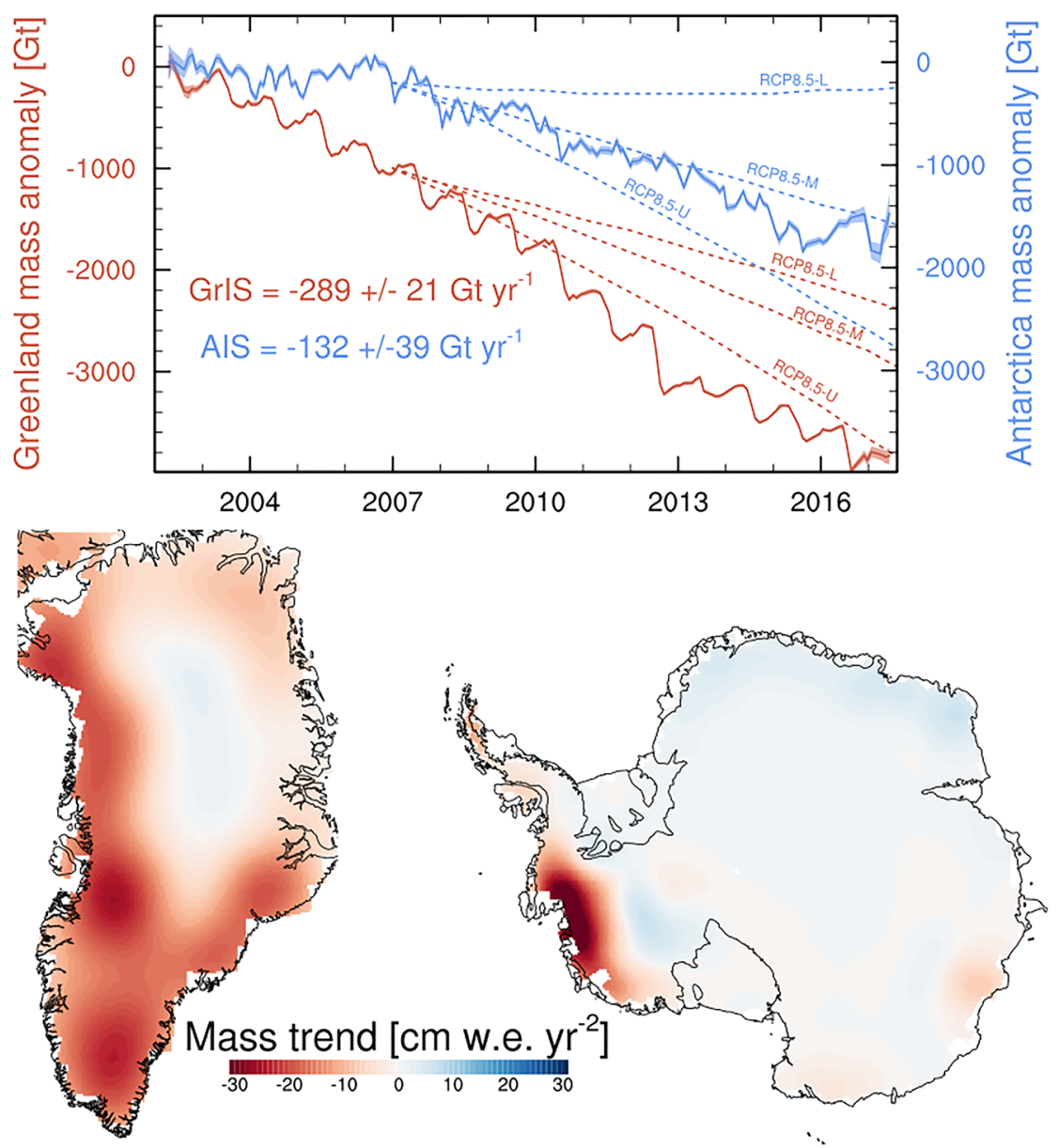

Figure 2. Time series and spatial patterns of ice sheet mass changes as measured by GRACE (2002-2017, Wise et al., 2018). In the upper plot, the solid lines show the GRACE mass balance from Antarctica (blue) and Greenland (red), with uncertainties contoured in the same color, and the three dotted lines show the lower, middle, and upper estimates of ice sheet mass loss in the business-as-usual, high-emissions RCP8.5 future scenario (IPCC, 2013). The numbers in the upper plot give the best linear fit for each ice sheet. The lower plots show the linear trend in units of $\mathrm{cm}$ water equivalent per year squared over the 2002-2017 period. 
potential to increase GMSL by $58 \mathrm{~m}$ (Fretwell et al., 2013; Morlighem et al., 2017). Although both ice sheets are currently losing mass, they do so at different rates via different mechanisms. The Antarctic Ice Sheet mass loss has increased threefold from 2002-2007 (0.2 $\pm 0.1 \mathrm{~mm} \mathrm{yr}^{-1}$ sea-level equivalent) to 2012-2017 $\left(0.6 \pm 0.1 \mathrm{~mm} \mathrm{yr}^{-1}\right)$ (Shepherd et al., 2018) and is mostly attributed to an increase in ice sheet discharge from glacier acceleration in West Antarctica (Gardner et al., 2018; Mouginot et al., 2014; Rignot et al., 2011). This increase is driven by a combination of an intrinsic geometric instability associated with marine-based ice sheets grounded on bedrock that deepens toward the center of the ice sheet and changes in the availability of warm, circumpolar deep water under floating ice shelves due to decadal atmospheric variability (Jenkins et al., 2016). Warm ocean water acts in tandem with atmospheric warming to thin and break up floating ice shelves (Khazendar et al., 2016; Liu et al., 2015; Paolo et al., 2015), leading to acceleration and retreat of the glaciers they buttress (Shepherd et al., 2018; Wouters et al., 2015). In contrast, the Greenland Ice Sheet mass loss is dominated by changes in surface mass balance (SMB, precipitation minus sublimation and meltwater runoff), with a smaller contribution caused by increased discharge from marine terminating outlet glaciers (Enderlin et al., 2014; Shepherd et al., 2018). Increase in runoff along the entire Greenland Ice Sheet margin is predominantly caused by atmospheric warming which promotes the intensification of ice sheet surface melt (Van den Broeke et al., 2016) and in turn rates of frontal (ocean) melting (Carroll et al., 2016).

Three independent observational methods are used to calculate current ice sheet mass loss rates: gravimetry, altimetry, and the input-output method (Shepherd et al., 2018). Each method has various strengths and weaknesses, with differing sensitivities to necessary corrections. Mass loss estimates from gravimetry (Velicogna \& Wahr, 2006) provide the only direct measure of mass change of the ice sheets, but require a correction due to glacial isostatic adjustment (GIA) processes, which dominates the uncertainty in derived mass-loss rates. GIA uncertainties are largest for Antarctic Ice Sheet, and while estimates vary among studies, a recent study (Caron et al., 2018) estimates Antarctic Ice Sheet GIA uncertainty to be $~ 40 \mathrm{Gt}$ (Gigaton $=10^{12} \mathrm{~kg}$ ) per year, which is approximately $30 \%$ of the mass trend. Greenland, on the other hand, has a GIA uncertainty of $\sim 13 \mathrm{Gt} / \mathrm{yr}$, which is less than $5 \%$ of the Greenland Ice Sheet mass loss trend. Repeated satellite and airborne laser and radar altimetry provide detailed surface height change observations over ice sheets, but conversion from surface height to mass loss requires knowledge of spatial and temporal variability in firn density, a parameter that is poorly constrained due to sparse observations within the ice sheet interior (Pritchard et al., 2009). The input-output method (Gardner et al., 2018; Rignot et al., 2011, 2019; Shirzaei \& Bürgmann, 2012, 2018)—the only method that gives a longer time series of ice sheet mass balance (Kjeldsen et al., 2015; Rignot et al., 2019; Mouginot et al., 2019)—combines observations of ice flux across the grounding line from satellite remote sensing with modeled SMB estimates. In general, most observational time series are less than 20 years old, making the detection of mass loss acceleration in the presence of large natural variability challenging, especially in ice sheet SMB (Wouters et al., 2013). Radar altimetry from CryoSat-2 (launched in 2010), as well as new gravimetry (GRACE Follow-On, GRACE-FO) and laser altimeter (ICESat-2) missions launched in 2018, will extend the time series and provide continuous monitoring of ice sheet changes in the coming years.

We depend on a suite of numerical models to project future ice sheet changes, and these models also contribute to constraining past and present behavior. These models are traditionally used in a stand-alone framework but are increasingly "coupled" to represent the full spectrum of ice sheet-climate interactions. Atmospheric (surface climate and SMB) and oceanic (e.g., temperature, salinity, circulation, sea ice) forcings to the ice sheet are supplied by a variety of climate models, which are either produced for the full globe (global circulation models and climate reanalysis) or spatially limited to one particular ice sheet and surroundings (regional climate models). While circulation models historically focused on coupled oceanland-atmosphere processes, modern earth system models also include the carbon cycle through dynamic atmospheric chemistry, as well as forcing of the ocean and atmosphere by the ice sheets. Regional climate models have become a preferred tool in representing ice sheet surface climate and SMB because they incorporate surface energy and snow hydrology processes and have the spatial resolutions $(\sim 5 \mathrm{~km})$ necessary to accurately model the Greenland Ice Sheet and individual Antarctic Ice Sheet basins (Agosta et al., 2019; Lenaerts et al., 2017; Noël et al., 2018; Van Wessem et al., 2018), often with steep topographic slopes around ice sheet margins. However, the accuracy of any regional climate model depends on the quality of the atmospheric forcing at the model domain boundaries, and observations necessary to evaluate climate and SMB over extensive areas of northern Greenland and Antarctica are lacking. 
Given geometric information, and provided appropriate atmospheric and oceanic input, ice sheet models represent the gravity-driven flow of solid ice, from the ice divide to the floating ice shelves. Recent model development has focused on improving the representation of grounding line migration (Pattyn et al., 2012, 2013; Seroussi et al., 2014; Seroussi \& Morlighem, 2018), ice front calving (Bondzio et al., 2018; Morlighem et al., 2016; Parizek et al., 2019; Todd et al., 2018) and the initial state of ice sheet models (Goelzer et al., 2018). In addition, models that couple ice sheet dynamics and gravitationally self-consistent SLCs are being developed (e.g., Gomez et al., 2015) and have shown that the coupling may play an important role in ice sheet stability (Gomez et al., 2018; Larour et al., 2019). Ice properties that cannot be directly measured (e.g., basal sliding coefficient, ice shelf rheology, and damage) are now estimated using data assimilation of ice surface velocity (Arthern et al., 2015; Borstad et al., 2012; Khazendar et al., 2015; Morlighem et al., 2010). Pattyn (2017) and Goelzer et al. (2017) review the recent advances in modeling the Antarctic and Greenland ice sheets, respectively.

The relation between ice sheets and climate is defined by a two-way connection: While ice sheets respond to atmospheric and oceanic conditions, they also influence the surrounding climate, for example, via the discharge of freshwater into oceans (Bronselaer et al., 2018; Schloesser et al., 2019) and changes in topographic geometries (e.g., Fyke et al., 2018). To this end, the ice sheet modeling community has increasingly focused on simulations that are fully coupled to climate models. The ongoing intercomparison of climate models (Sixth Coupled Model Intercomparison Project; CMIP6) includes several models that couple to dynamical ice sheet models for the first time (Nowicki et al., 2016). The initial development has been associated with atmosphere/ice sheet coupling over the Greenland Ice Sheet (e.g., Lipscomb et al., 2013). Major, ongoing challenges of such models include matching the temporal and spatial scales of the ice sheet model with the global models, providing accurate initial conditions for the ice sheet model, and allowing for the variable extent of the ice-covered surface. Initial improvements have been made in the representation of SMB in earth system models guided by lessons from regional climate models (e.g., Vizcaíno et al., 2013). Advances in the coupling of ocean and ice sheet models (e.g., Goldberg et al., 2018) will continue to improve our ability to model the Antarctic Ice Sheet, particularly in West Antarctica, where oceanic forcings are likely to play a pivotal role in future ice sheet mass loss. Recent studies have demonstrated the impact of ice-ocean coupling on such sub-ice-shelf melt rates and grounding line migration (Golledge et al., 2019; Jordan et al., 2017; Seroussi et al., 2017).

The ice-sheet mass loss to the ocean strongly influences regional sea level, as associated changes in Earth's GRD responses dictate the spatial distribution of water across the global ocean (Farrell \& Clark, 1976; Milne \& Mitrovica, 1998; Mitrovica et al., 2001). These so-called "sea-level fingerprints" are crucial to determining regional SLC (Figures 3a and 3b). In general, mass loss causes a sea level fall in the near field, a reduced sea-level rise at intermediate distances, and a greater-than-global-mean sea-level rise at larger distances. Sea-level fingerprints can be computed for specific portions of ice sheets, enabling accurately quantified sensitivities of basin-scale ice mass loss to local sea-level rise at any coastal cities. The collapse of Petermann Glacier in Greenland, for example, would lead to 38\% lower sea-level rise at New York and 20\% higher sea-level rise at Tokyo relative to the global mean (Larour et al., 2017; Mitrovica et al., 2018). Estimating the current and projecting future contributions from the two ice sheets-including spatial variability in the contribution across each ice sheet-is thus critical to understanding regional SLC. Updated assessments of the regional impact on coastal cities will continue to be made as our understanding of mass loss from ice sheets advances and projections are improved.

\subsection{Uncertainties and Future Outlook}

While significant progress has been made in recent years as described above, estimating future ice sheet contributions to sea level relies on models, which contain large uncertainties. These uncertainties exist in every stage of modeling ice sheets in future climates, from fundamental understanding of ice sheet physical processes (e.g., DeConto \& Pollard, 2016), initialization (Goelzer et al., 2018), parameter, and boundary condition choices (e.g., Larour et al., 2012; Nias et al., 2016; Schlegel et al., 2015), to the quality of atmospheric and ocean forcings, which in turn rely on climate models with all their associated uncertainties (Nowicki \& Seroussi, 2018; Robel et al., 2019); all of these uncertainties can limit the quality of model projections. For example, climate model-driven projections reported in the Fifth Assessment Report of the Intergovernmental Panel on Climate Change (IPCC) underestimated mass loss from 2006 to present, 

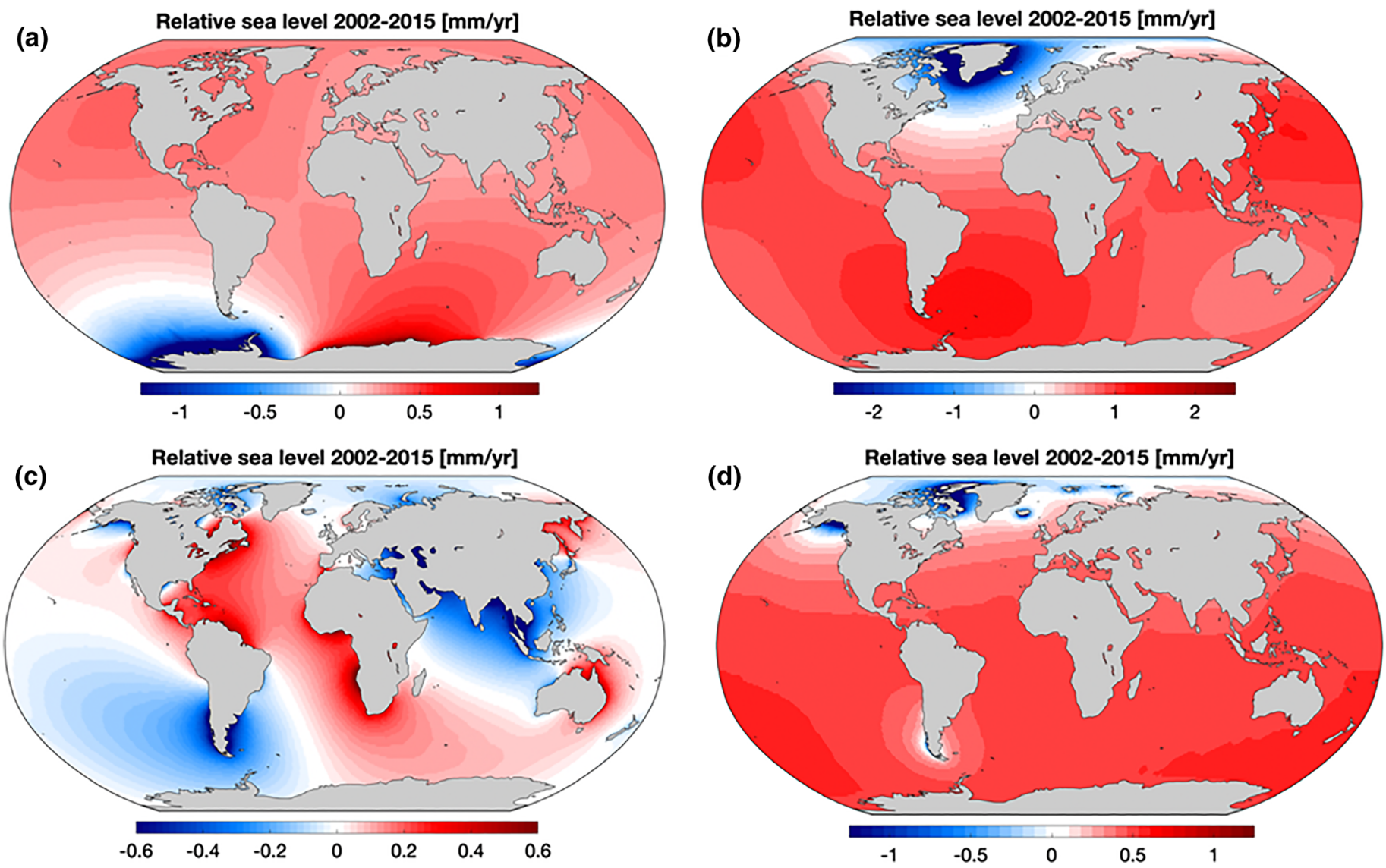

Figure 3. Contribution to relative sea-level rise (mm/year) from 2002 to 2015 from (a) Antarctica Ice Sheet mass loss, (b) Greenland Ice Sheet mass loss, (c) terrestrial water storage variability, and (d) glacier mass loss. Adapted from Adhikari and Ivins (2016).

especially in the case of the Greenland Ice Sheet, including in the strongest warming (business-as-usual) RCP8.5 scenarios (Figure 2). This example highlights the need for extensive evaluation of present-day model performance, careful selection of model forcing, and, on the longer term, a focus on earth system model development to improve high-latitude atmospheric (e.g., clouds, radiation, precipitation) and oceanic processes, horizontal resolution and/or statistical downscaling (Lenaerts et al., 2019). Multimodel ensembles and intercomparisons (e.g., the Ice Sheet Model Intercomparison Project, ISMIP6; Nowicki et al., 2016) will also provide critical contributions to uncertainty quantification.

Ice sheet contributions are especially important when planning for future SLC (e.g., Garner \& Keller, 2018; Oppenheimer \& Alley, 2016; Sriver et al., 2018; Sweet et al., 2017). The research community is increasingly employing probabilistic approaches when making projections of future sea-level contributions from ice sheets (Edwards et al., 2019; Little et al., 2013; Ritz et al., 2015; Schlegel et al., 2018), which are necessary for holistic probabilistic projections of sea-level rise (e.g., Kopp et al., 2014, 2017; Perrette et al., 2013, Slangen et al., 2014). Probabilistic projections, however, are subject to the same limitations as the models or structured expert judgements (e.g., Bamber \& Aspinall, 2013; Bamber et al., 2019) used to construct them. There is some utility in turning to past analogs of high sea-level contributions from ice sheets (e.g., the last interglacial or Pliocene) to calibrate ice sheet models and improve probabilistic projections (e.g., Edwards et al., 2019), but these too are impacted by prior model uncertainties, as well as by the uncertainties in paleo reconstructions. Furthermore, the efficacy of using modern ice sheet trends for constraining future contributions remains an active area of research (Kopp et al., 2017). As these deep uncertainties in ice sheet contributions are elucidated and probabilistic projections continue to improve, they will inform policy decisions that are based on projected probabilities that regional- and global-scale sea levels will exceed critical levels (e.g., Bakker et al., 2017; Buchanan et al., 2016; Rasmussen et al., 2018; Sweet et al., 2017). 
As ice sheet models improve in their resolution, initialization procedures, and process implementation, they become increasingly reliant on observations to both force their behavior and validate their performance. Accurate reproduction of ice sheet dynamics, especially near grounding lines, requires high-resolution surface and bed topography (Aschwanden et al., 2016, 2019; Morlighem et al., 2014; Nias et al., 2018), estimates of basal shear stress (Parizek et al., 2013), and sub-ice shelf bathymetry (Schodlok et al., 2012). Geometric constraints on outlet glacier dynamics have improved dramatically in recent years (e.g., Greenbaum et al., 2015; Morlighem et al., 2017; Vaughan et al., 2012), but technological advancements (e.g., radar tomography; Al-Ibadi et al., 2018) and geophysical methods development (toward observational validation of subsurface model parameters such as basal shear stress (Brisbourne et al., 2017), temperature (MacGregor et al., 2015; Schroeder et al., 2016), and englacial velocity (Holschuh et al., 2017, 2019; Leysinger Vieli et al., 2007) could drive significant improvement in model projections. Importantly, new aerogeophysical campaigns and satellite missions will be required to collect data optimized for these new techniques, as well as to fill gaps in existing subsurface observations. Ice sheet model development should focus on including geophysical observations directly, and extending the data assimilation capabilities from the inclusion of snapshot surface observations to the inclusion of time series data (Goldberg \& Heimbach, 2013; Larour et al., 2014) to take full advantage of the abundance of remote sensing observations now available.

\section{Contributions From Glaciers}

\subsection{Current State of Knowledge}

Glaciers other than the two large ice sheets store large volumes of fresh water that, when released, can seasonally augment river discharge particularly during warm and dry months (Huss et al., 2017; Huss \& Hock, 2018; Immerzeel et al., 2010; Kaser et al., 2010) and contribute to changes in sea level as glaciers grow and shrink in response to changes in atmosphere and ocean forcing (Gardner et al., 2013; Kaser et al., 2006; Zemp et al., 2019). Globally, there are an estimated 200,000 glaciers covering an area of 706,000 $\mathrm{km}^{2}$ (Randolph Glacier Inventory, Consortium 2017). If melted completely they would raise GMSL by $0.32 \pm 0.08 \mathrm{~m}$ (Farinotti et al., 2019). Glaciers can be grouped into 19 distinct regions as defined by the Randolph Glacier Inventory (Pfeffer et al., 2014). Of these 19 regions, only 12 have the capacity to change sea level by $\gtrsim 5 \mathrm{~mm}$ : six Arctic island regions, three High Mountain Asia regions, Alaska, South America, and the Antarctic islands. These 12 regions account for $99 \%$ of the total glacier volume. Relative to the much larger Antarctic and Greenland ice sheets, glaciers are typically located in more temperate environments with a large fraction of their surface area subjected to seasonal melting. This characteristic makes glaciers particularly sensitive to changes in climate. As with the ice sheet contributions discussed in the previous section, many of the estimates provided here are of the contributions of glaciers to GMSL. However, the specific geographic location of loss leads to regional variability in the resulting SLC. This spatial variability can be conveyed in sea-level fingerprints for the glaciers, computed similarly to those for the ice sheets (e.g., Adhikari et al., 2016; Slangen et al., 2014; Figure 3).

Over the last decade, nearly all glacierized regions on Earth have been in a state of mass loss, contributing $0.71 \pm 0.08 \mathrm{~mm} \mathrm{yr}^{-1}$ to GMSL over the period 2003-2009 (Gardner et al., 2013) which corresponds to $29 \pm 13 \%$ of the observed GMSL rise during that period. Reager et al. (2016) extended the record of glacier mass change through November 2014 for all regions excluding High Mountain Asia and those surrounding the Greenland and Antarctic ice sheets. They found rates of loss to be $~ 17 \%$ higher for the 2002-2014 period than the 2003-2009 period due to accelerated rates of loss from Alaska, Canadian Arctic, and the Southern Andes. Arctic and Alaskan glaciers accounted for $75 \%$ of all glacier contributions to sea-level rise over the 2002-2014 period (Reager et al., 2016), assuming constant 2003-2009 rates of loss for High Mountain Asia, Greenland, and Antarctic glaciers (Gardner et al., 2013). Excluding Greenland and Antarctic glaciers, Wouters et al. (2019) suggest that the rate of glacier loss over the longer 2002-2016 period (Figure 4) has returned to the 2003-2009 rate by Gardner et al. (2013). Extrapolating glaciological and geodetic data from 450 and greater than 19,000 glaciers, respectively, Zemp et al. (2019) estimated a glacier sea-level contribution of $0.92 \pm 0.39 \mathrm{~mm} \mathrm{yr}^{-1}$ over the period 2006-2016.

These rates of loss are historically unprecedented in the observational record (Zemp et al., 2019) and can be attributed, to a large degree, to anthropogenic warming of the troposphere (Marzeion et al., 2014). A recent analysis of the glacier projections using up to six different glacier evolution models (Bliss et al., 2014; 

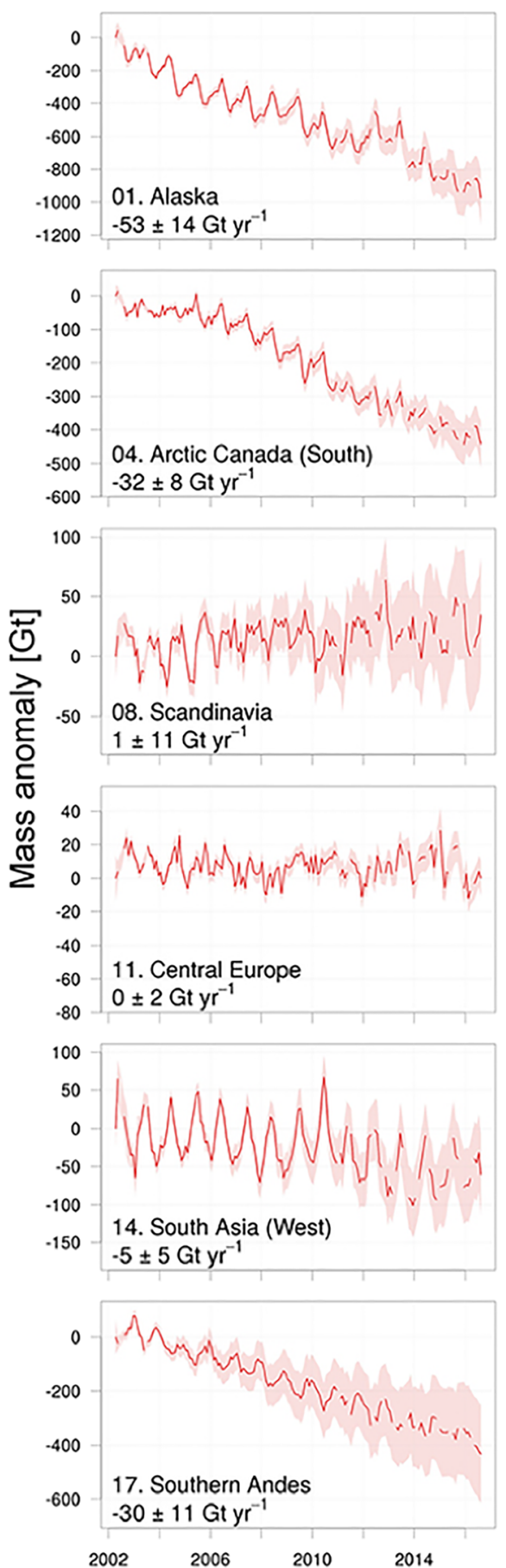
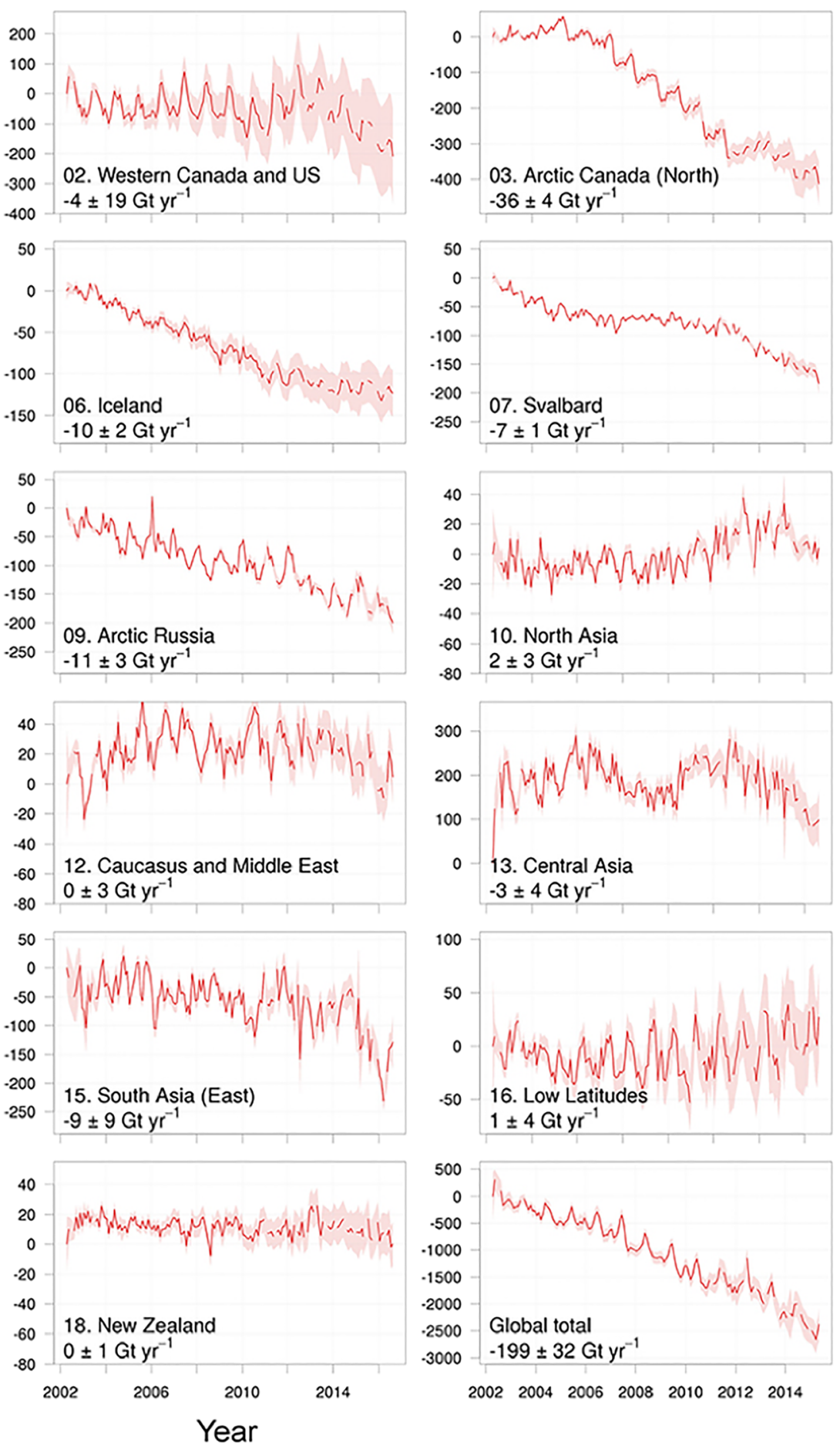

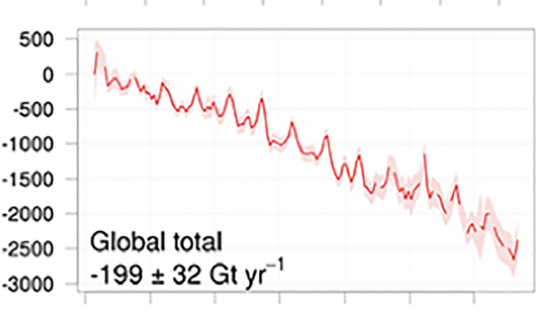

2002200420062008201020122014

Figure 4. Time series of cumulative mass anomalies from GRACE for all primary glacier regions of the Randolph Glacier Inventory, except the Greenland and Antarctic periphery, covering the time period from 2002 to 2017. From Wouters et al. (2019).

Hirabayashi et al., 2013; Huss \& Hock, 2015; Marzeion et al., 2012; Radić \& Hock, 2014; Slangen et al., 2017) forced with output from 8 to 15 general circulation models from the Coupled Model Intercomparison Project 5 (CMIP5) estimates that glaciers (including those in the Greenland and Antarctic periphery) will contribute $94 \pm 25 \mathrm{~mm}$ to GMSL rise (mean of 46 model runs \pm 1 standard deviation) over the period 2015 to 2100 under the low-emission scenario RCP2.6, and $200 \pm 44 \mathrm{~mm}$ (88 models runs) under the high-emission RCP8.5 scenario (Hock et al., 2019). 
The last two decades have seen significant advances in our ability to measure glacier change on global scales. Monitoring of ice height changes at low-gradient slopes became possible in the early 1990s with the launch of conventional ocean radar altimeters. These altimeters were, however, limited in their ability to resolve volume changes of glaciers located in high-relief regions. The launch of NASA's ICESat satellite laser altimeter, which operated from January of 2003 to October 2009, allowed glacier height changes to be routinely measured from space. Such measurements were complemented by gravity measurements collected by GRACE, which provided estimates of mass changes at larger glacier systems. Together, these satellites provided the first global picture of glacier mass change as seen from space (Gardner et al., 2013; Jacob et al., 2012; Wouters et al., 2019) and led to the identification of large spatial sampling biases in the ground monitoring network (Gardner et al., 2013). Such measurements are critical for improving our understanding of the response of glaciers to external forcing (e.g., Moholdt et al., 2012) and for calibrating/validating the models used to project future rates of loss (e.g., Huss \& Hock, 2015; Marzeion et al., 2017; Radić et al., 2014).

The success of GRACE and ICESat motivated the launch of GRACE-FO in May 2018 and ICESat-2 four months later in September of 2018. Technological advances on ICESat-2 allow it to continuously collect high-precision and dense along-track measurements $(0.7 \mathrm{~m})$ with a narrow illumination footprint $(17 \mathrm{~m})$ that is well suited to measuring glacier height changes in areas of complex topography. ICESat- 2 and GRACE-FO will extend the time series of regional glacier mass change and provide increased detail and new insights to guide future modeling efforts. NASA also operated an airborne mission, Operation IceBridge that was designed to help bridge the nearly 9-year gap in satellite laser altimetry between ICESat and ICESat-2. Operation IceBridge began operations in 2009 and operated through the fall of 2019. While most Operation IceBridge data were collected over the ice sheets, data were also collected over the Canadian Arctic and Alaska. These data have provided details on the drivers of mass loss in these regions during the hiatus in satellite laser altimetry (Gardner et al., 2013; Larsen et al., 2015). In addition to satellite gravimetry and altimetry there has been a recent explosion in the use of large satellite optical imagery data sets to measure glacier elevations and velocities (Dehecq et al., 2015; Porter et al., 2018; Willis et al., 2012). Such efforts have advanced the understanding of how glacier flow responds to regional scale forcing (Dehecq et al., 2019) and provided improved detail on the mechanisms responsible for observed changes in glacier mass (Brun et al., 2017).

\subsection{Uncertainties and Future Outlook}

To make further progress in constraining future rates of glacier loss, efforts need to be dedicated to improving historical and present-day estimates of global glacier mass balance, which will provide the context for recent changes as well as improved data for calibration of glacier mass balance models. A promising source of data to reconstruct glacier changes over the past 50 to 60 years is airborne and declassified satellite stereo imagery (Gardner et al., 2012; Pieczonka \& Bolch, 2015). Working with such data is challenging, as they often need to be digitized and corrected for poorly known camera parameters and ground control. Further investment in automated techniques to extract high-accuracy elevations from such data would help to accelerate their utilization. Reconstruction of long-term (>60 year) historical patterns of glacier change can be improved through mapping of trimlines, moraine positions, and uplift rates (Glasser et al., 2011; Larsen et al., 2005). Additional analysis of existing field observations to incorporate improved inventories and knowledge of regional extrapolation methods will help reconcile remaining discrepancies between regional estimates of mass change derived from in situ data and remote sensing observations (Kaser et al., 2006; Pfeffer et al., 2014). In particular, potential biases in the location or sizes of sampled glaciers relative to the full population should be more thoroughly explored (Gardner et al., 2013).

Integration of field and remote sensing observations with model simulations is necessary to accurately project future trends in glacier contribution to sea level. Conventional field observations of mass balance at "benchmark" glaciers will remain a high priority to ensure continuity with long-term records, since these provide unique opportunities for model calibration. Locations of long-term monitoring sites, within the context of characterizing regional glacier behavior, should be revisited given the availability of previously unavailable satellite data. This is particularly important for large glacierized regions with steep gradients in environmental conditions. Field studies at these and other sites should be expanded to include detailed observations of surface and dynamic processes. Improved parameterization of surface albedo, which controls the dominant term in the surface radiation budget, can be achieved through studies of snow and ice 
crystal grain sizes (Painter et al., 2009) and the impacts of dust/black carbon (Flanner \& Zender, 2006). Improved understanding of the impact of supraglacial debris on surface melt rates (Östrem, 1959) can be achieved by mapping debris cover extent (Scherler et al., 2018) and debris thickness (Kraaijenbrink et al., 2017; Rounce et al., 2018) globally. The conversion of volume to mass change in geodetic remote sensing assessments remains a large source of uncertainty (Huss, 2013) and can be better constrained through field measurements of near-surface densification rates. Glaciers that terminate in lakes or the ocean have the potential for rapid changes through poorly understood calving mechanisms (Moholdt et al., 2012) and rates of subaqueous melt (Motyka et al., 2003; Sutherland et al., 2019) require expanded observations of ice thickness, grounding line locations and lake/fiord conditions. Finally, field programs should include observations of stream discharge where possible since this provides valuable information on the integrated water balance of glacierized watersheds.

The spatial coverage and temporal resolution of remote sensing data introduce challenges when attempting to integrate observations across regions. Community standards on how to leverage the strengths of each observation platform should be developed, building on past global estimates (Gardner et al., 2013). Large challenges remain with respect to projecting glacier mass changes on a global scale (see Radic and Hock (2014) for review). Current models typically use simple temperature-index methods and most models exclude mass loss by calving and submarine melt (e.g., Hirabayashi et al., 2013; Huss \& Hock, 2015; Marzeion et al., 2012; Radić \& Hock, 2011; Slangen et al., 2012). Most models also use scaling methods and simple geometric models to account for glacier geometry changes as the mass changes. Methods for explicitly incorporating glacier ice flow adjustments to climate forcing into individual glacier models (e.g., Adhikari \& Marshall, 2013) and regional scale models (e.g., Zekollari et al., 2019) should be more fully explored.

The highly variable terrain of alpine regions creates complex patterns in meteorological conditions that pose significant challenges to accurately quantifying precipitation, temperature, and other variables needed to force glacier evolution models. At present, between $20 \%$ and $50 \%$ of the uncertainty in projections of global glacier changes to the year 2100 is due to the spread in existing global circulation models (Huss \& Hock, 2015). Significant improvement to model accuracy can be achieved through forcing the glacier models with global circulation model climate projections that have been downscaled from regional climate models run at the highest possible spatial resolution.

\section{Contributions From Changes in Land Water Storage}

\subsection{Current State of Knowledge}

Both human activities and natural climate variability have impacted the storage of water on the continents, including changes in river flow and evolving patterns of water transport between the global land masses, atmosphere, and oceans. These changes ultimately affect the state of global sea level, and also have a regional fingerprint that contributes to spatial variability in SLC (Figure 3c). For instance, the cumulative impoundment of river water in dams and reservoirs has reduced the outflow of water to the oceans and generated regional loading and gravitational responses (Fiedler \& Conrad, 2010), while other activities, such as groundwater depletion, have caused regional changes to the water stored on land and a positive contribution to sea level (Chao et al., 2008; Church et al., 2013; Wada et al., 2012). Additionally, recent data from GRACE have shown that natural climate variability in the global water cycle perturbs the rate of SLC at shorter (interannual to decadal) time scales, which can influence closure of the global water budget over different observational periods (Cazenave et al., 2014; Dieng et al., 2015; Hamlington et al., 2019; Reager et al., 2016; Rietbroek et al., 2016). The effects of these two types of processes are distinct. On one hand, the net effects of anthropogenic processes such as reservoir construction (which causes a GMSL fall) and groundwater depletion (which causes a GMSL rise) have acted to decrease net global land water storage, reducing the secular trend in sea-level rise over the past several decades (Church et al., 2013; Gregory et al., 2013; Wada et al., 2016). Alternatively, natural global water cycle variability can augment or offset GMSL rates by as much as $\pm 0.7 \mathrm{~mm} \mathrm{yr}^{1}$ for periods of a decade or shorter (Reager et al., 2016) and can vary substantially in magnitude from one decade to the next. While terrestrial land water storage changes are generally a secondary contributor in terms of magnitude to the long-term global sea-level trend budget, the proper accounting of both human activity and water cycle variability is necessary for accurate sea-level budget closure across time and space scales. 
A recent study by Wada et al. (2017) estimated that humans have so far captured a total of $10,416 \mathrm{~km}^{3}$ of water behind dams. This represents the equivalent of a $29 \mathrm{~mm}$ decrease in global mean sea level since 1900. When global dam-building activity was at its historical highest during the years 1950 to 2000, average rate of SLC was offset by $-0.51 \mathrm{~mm} \mathrm{yr}^{-1}$ due to reservoir impoundment. This process represents a first-order contributor to the complete natural and anthropogenic sea-level budget over the past 100 years, but the activity has now slowed substantially due to a decrease in global dam-building activities in recent decades. However, current planning activity suggests a likely resurgence of reservoir construction for hydropower in the coming 20 years (Zarfil et al., 2014).

Groundwater depletion for human use represents the largest current secular trend in the global land water storage budget and also serves to drive much of the spatial variability in the pattern shown in Figure 3c. Data from GRACE has provided a means to monitor continental water storage and groundwater changes globally from a net mass change perspective (Jacob et al., 2012; Rodell et al., 2009; Shamsudduha et al., 2012; Strassberg et al., 2007; Tiwari et al., 2009; Voss et al., 2013). These observations offer a complement to studies applying large-scale hydrological models to estimate groundwater declines and the combination of models with the GRACE data can be used to verify model accuracy. Wada et al. (2016) challenged the assumptions of many previous studies that all the depleted ground water ends up into the ocean by tracking the fate of groundwater used in irrigation. They estimate that only $\sim 80 \%$ of depleted groundwater eventually flows to the ocean, while the other fraction ends up in different locations on land. They estimated a reduced contribution to GMSL ranging from $0.02 \pm 0.004 \mathrm{~mm} \mathrm{yr}^{-1}$ in 1900 to $0.27 \pm 0.04 \mathrm{~mm} \mathrm{yr}^{-1}$ in 2000 . Next to the increase in ocean mass, land subsidence resulting from groundwater pumping in certain regions can have a large impact on relative sea-level variability. This process is discussed in detail in section 7.

Natural changes in the interannual to decadal cycling of water can have a large effect on the rate of SLC over decadal and shorter periods (Lettenmaier \& Milly, 2009; Llovel et al., 2011; Milly et al., 2003). For instance, El Niño-Southern Oscillation (ENSO)-driven modulations of the global water cycle are important in decadal-scale sea-level budgets and can mask underlying secular trends in SLC (Cazenave et al., 2014; Hamlington et al., 2019). Because of this large interannual variability, substantial TWS trends are found in the GRACE record, but the sign and magnitude of this trend strongly depend on the time window over which the trend is estimated. For example, Reager et al. (2016) and Scanlon et al. (2018) find a net ocean mass loss due to TWS changes over 2002-2014 (Figure 5), while a more recent study suggests a positive contribution to GMSL (Kim et al., 2019). While this term can be large and is important in the interpretation of the sea-level record, it is arguably the most challenging term in the land water budget to quantify. Water resource models and land surface models still struggle with simulating the total water storage changes (Scanlon et al., 2018), which is partially linked to their inability to model deep water storage changes, as it requires information on deep-soil properties on a global scale. A recent parametrization approach has been introduced by Humphrey et al. (2017), in which a simple land water storage model is fed with precipitation estimates and trained using GRACE observations, and shows that the large TWS variability observed over the GRACE era is not the result of an unique event and similar variations have taken place throughout the twentieth century.

\subsection{Uncertainties and Future Outlook}

Generally, we expect the rate of human-driven land water storage changes to continue at current rates for several decades into the future, while the climate-driven variability in the water cycle will respond more rapidly to transient climate conditions such as ENSO and Pacific Decadal Oscillation. However, there remain discrepancies in several of the component estimates. For many components, uncertainty due to extrapolation to a global domain and to future time periods still remains, and individual contributions likely vary substantially due to changing human and climate influences over time. Observational uncertainty in gravity-based approaches to global and regional mass budget closure, including groundwater monitoring, are affected by uncertainties in GIA and geocenter corrections applied in these approaches (e.g., Blazquez et al., 2018).

In order to refine the accuracy of current estimates and monitor changing human and climatic influences, it is imperative to continue monitoring the terrestrial water cycle, including surface water storage and groundwater storage, from space. The GRACE-FO mission will extend the observational record into the next decade for global mass change. Continued monitoring efforts from satellite gravimetry coupled with in situ studies will provide a longer record and allow more precise determination of uncertain terms in the global mass 

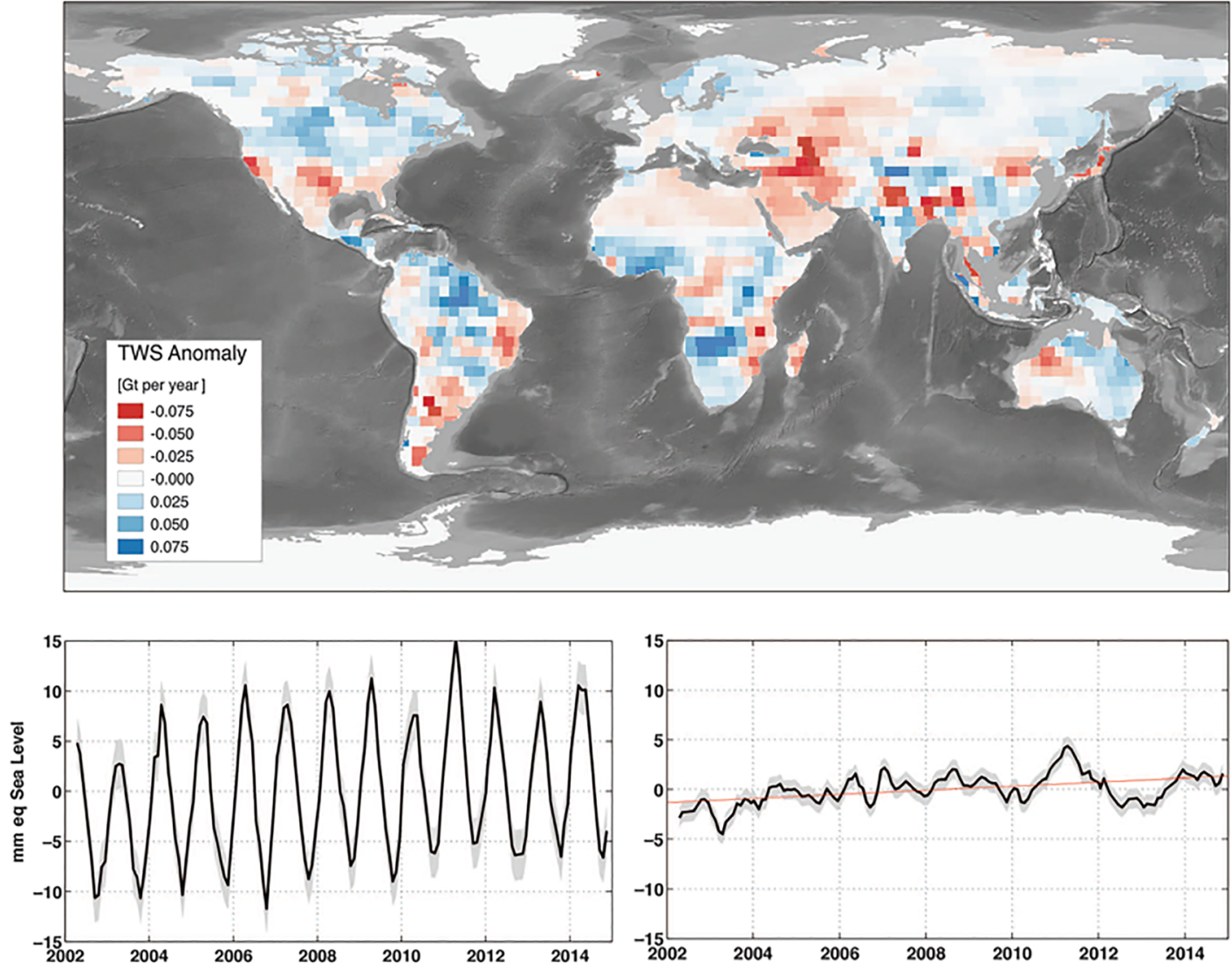
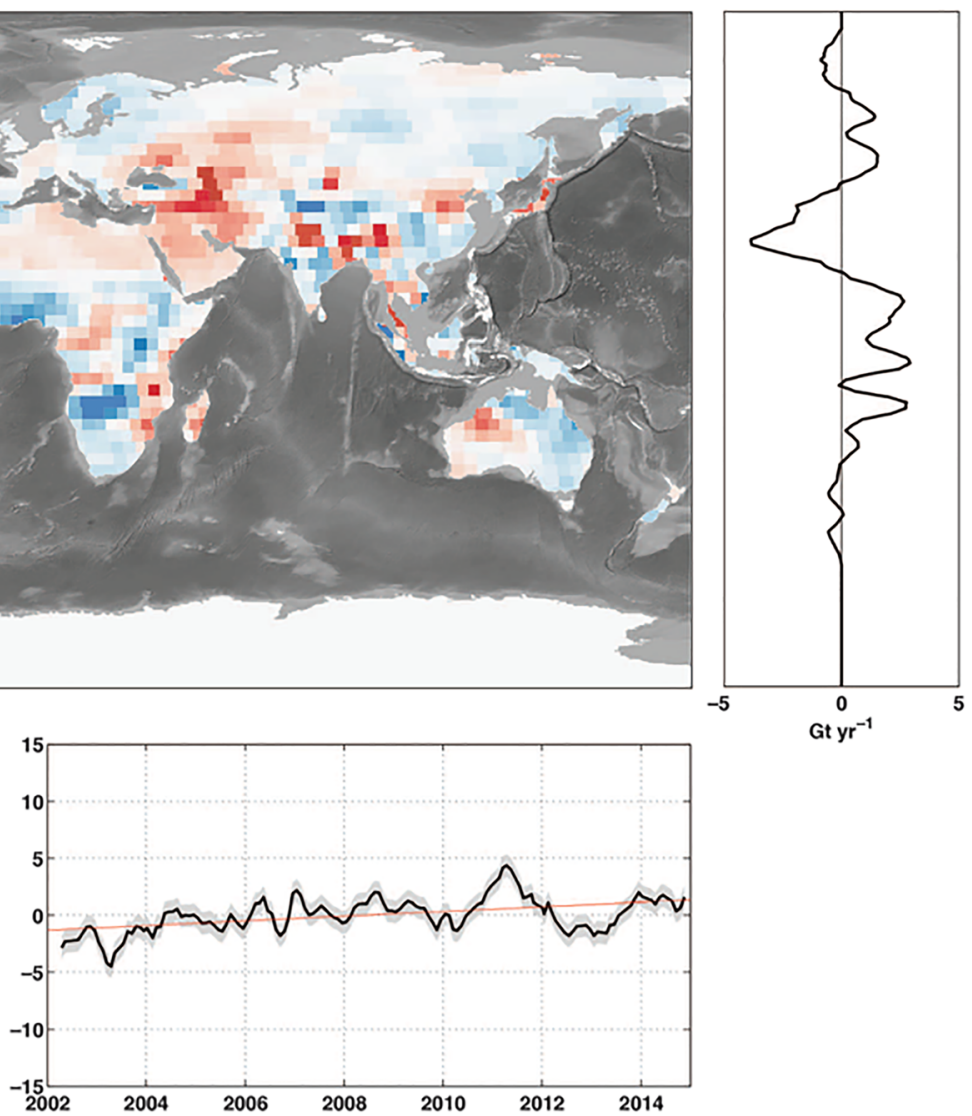

Figure 5. An example of trends in land water storage from GRACE observations, April 2002 to November 2014. Glaciers and ice sheets are excluded. Shown are the global map (gigatons per year), zonal trends, and full time series of land water storage (in $\mathrm{mm} \mathrm{yr}^{-1}$ SLE). Following methods details in Reager et al., (2016), GRACE shows a total gain in land water storage during the 2002-2014 period, corresponding to a sea-level trend of $-0.33 \pm 0.16 \mathrm{~mm} \mathrm{yr}^{-1} \mathrm{SLE}^{\text {. These }}$ trends include all human-driven and climate-driven processes in Table 2 and can be used to close the land water budget over the study period. From Reager et al. (2016), reprinted with permission from AAAS.

budget. Additionally, longer records of regional groundwater changes in response to changing water supply and demand will allow for better extrapolation of these effects into the future.

In the next decade, the availability of large ensemble simulations of Earth system models will allow for improved determination of human forcing and its influence on sea-level contributions associated with hydrology. Continued improvements in the resolution and process representation of land surface models will also allow for better understanding of changing regional hydrology, including the inclusion of human activities and water consumption. These model developments will be supported by future observing platforms. For example, the Surface Water and Ocean Topography (SWOT) mission (Biancamaria et al., 2016) will provide the first observational estimate of global continental river discharge, thus improving our understanding of global and regional water cycles. Continued studies of terrestrial hydrology, river discharge, and the effects of river plumes on coastal ocean dynamics will deepen insight into the complex set of processes that can influence regional sea-level variability.

\section{Steric Sea-Level and Ocean Dynamics}

\subsection{Current State of Knowledge}

There has been a large-scale warming of the upper $700 \mathrm{~m}$ of the ocean observed since the 1970s, increasing the upper ocean heat content (Abraham et al., 2013; Balmaseda et al., 2013; Boyer et al., 2016; Cheng et al., 2017; Domingues et al., 2008; Durack \& Wijffels, 2010; Gleckler et al., 2016; Ishii \& Kimoto, 2009; Ishii et al., 2017; Levitus et al., 2012; Lyman \& Johnson, 2014; Roemmich et al., 2015; Figure 6). This warming leads to a thermosteric rise in sea level, as warm water is less dense than colder water. Changes in salinity 


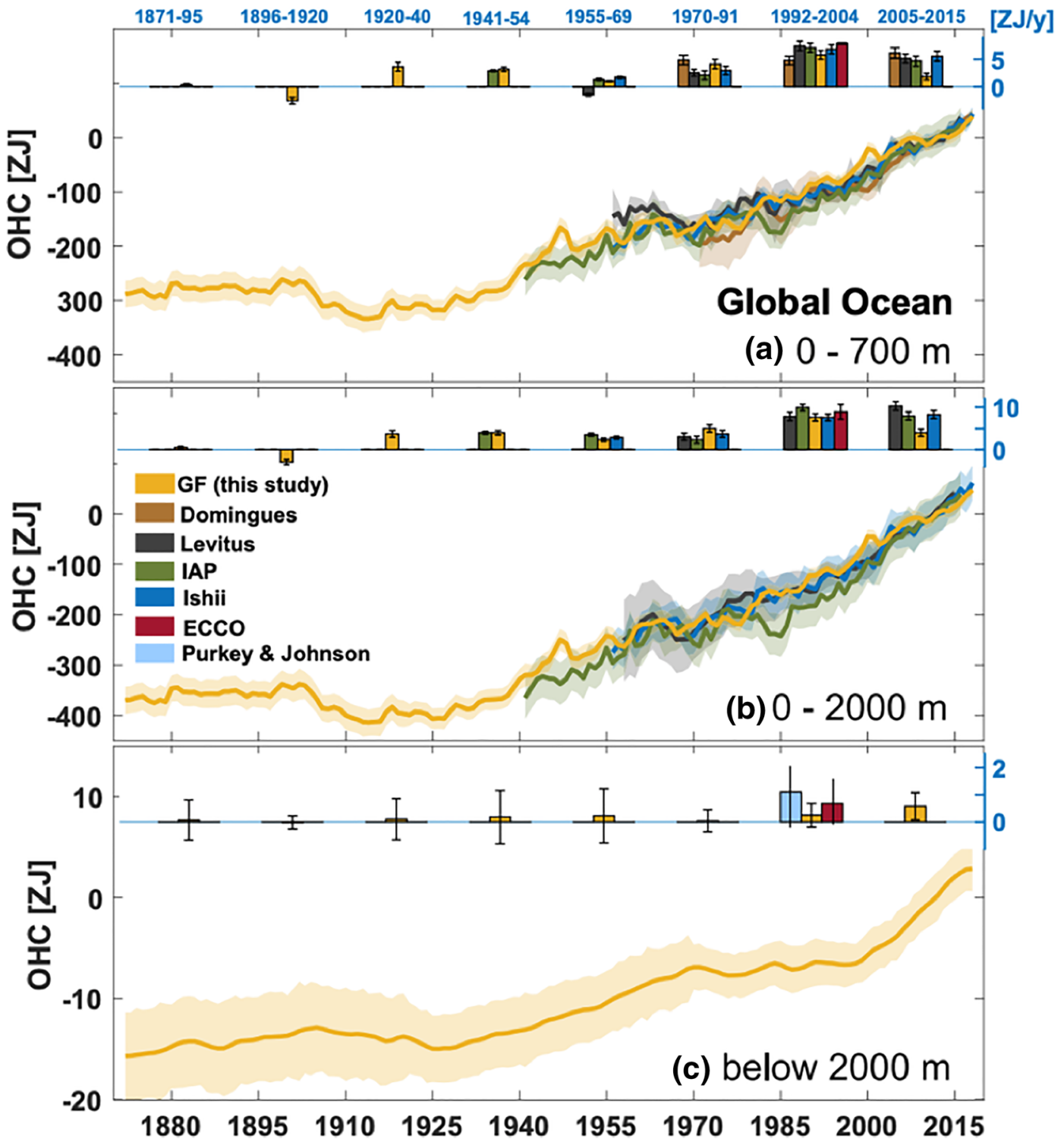

Figure 6. Global ocean heat content time series and trends for Green's functions and observational estimates relative to 2006-2015 for different ocean depths: (a) 0-700 m, (b) 0-2000 m, and (c) below 2000 m. From Zanna et al. (2019).

also contribute halosteric effects to sea level (e.g., Munk, 2003) either through spatial changes in water mass properties (e.g., Llovel \& Terray, 2016; Suzuki \& Ishii, 2011; Volkov et al., 2017), changes in the net freshwater flux through the ocean surface (precipitation minus evaporation; Köhl et al., 2014; Llovel \& Lee, 2015), inputs of glacier and ice sheet meltwater (Lorbacher et al., 2012), and river discharge (Piecuch et al., 2018). The thermosteric and halosteric effects on sea level due to a freshwater flux need to be separated for attribution purposes (Jordà \& Gomis, 2013; Lowe \& Gregory, 2006). From 1972 to 2008, thermosteric sea-level rise explained roughly 50\% of observed GMSL rise (Church et al., 2013; Church \& White, 2011; Gregory et al., 2013) with a negligible contribution from halosteric effects. With accelerating contributions from land ice (see sections 3 and 4), that percentage has dropped to 33\% since 2005, as estimated using observations from Argo profiling floats (Cazenave et al., 2018; Chambers et al., 2017).

As seen in the satellite altimeter record, regional sea-level variability can be considerably larger than the GMSL change (Figure 1). This variability is driven by the ocean's dynamic response to forcing by atmospheric variability (which itself is coupled to the ocean via heat and freshwater fluxes). For instance, on the shelf of the eastern Atlantic Ocean, low-frequency along-slope wind variability and dynamic SLC have 
been observed to be synchronous with interannual-to-decadal ocean circulation changes (Chafik et al., 2019). Steric SLC can result from changes in the strength and location of ocean currents, upwelling signals, and Rossby and Kelvin waves that can propagate zonally and along coastlines. For example, it has been found that the wind stress curl associated with the Pacific Decadal Oscillation explains the significant multidecadal variability that was manifest as a sea-level rise along the Pacific coast of North America from 1993 to 2009 that was considerably smaller than the global average (Bromirski et al., 2011), while sea level in the western Pacific rose at a level 3 times higher than the global mean (Merrifield \& Maltrud, 2011). Similarly, interannual variability in the trade winds influences the rate of SLC throughout the northeast Pacific (Thompson et al., 2014). Rossby waves can impinge upon the eastern seaboard of the USA, generating coastal waves that modulate the annual cycle in coastal sea level on interannual to multidecadal time scales (Calafat et al., 2018). The extent to which open-ocean sea-level signals are communicated to the coast is influenced by western boundary flows, frictional shelf dynamics, the latitudinal dependence of the Coriolis parameter, and details of seafloor bathymetry (e.g., Minobe et al., 2017; Wise et al., 2018, 2020).

Because the utility of observations and free-running models is limited due to the length and span of observational coverage and inexact agreement between models and observations, tools have been developed to synthesize observations in a physical sense to further explore the mechanisms behind SLCs. Dynamically consistent ocean state estimates such as the Estimating the Circulation and Climate of the Ocean (ECCO) framework have, therefore, been heavily utilized to understand ocean heat content and steric sea-level variability. Zanna et al. (2019) have used the ECCO framework to reconstruct ocean heat storage and transport, revealing a gain in heat content of $43.8 \pm 9.1 \times 10^{22} \mathrm{~J}$ (net heating of $0.49 \pm 0.1 \mathrm{~W} \mathrm{~m}^{-2}$ ) since 1871 , with the recent deep ocean heat content increase accelerating more quickly than the shallow ocean heat content increase (Figure 6). Their results demonstrate an active role of ocean circulation in shaping patterns of the ocean heat storage. In particular, the accelerated warming in the Atlantic basin over the past six decades can be attributed to heat convergence from changes in ocean circulation.

These results build upon previous findings using ECCO, which have analyzed drivers of ocean heat content and steric sea-level variability over a range of time scales, but coarse ( $1^{\circ}$ horizontal resolution) spatial scales. An analysis of the causes of interannual variations in steric sea level from 1993 to 2004 revealed that advection dominates in the tropical Indian and Pacific Oceans, advection by large-scale ocean circulation and diffusion by geostrophic eddy effects are equally important in extratropical regions, and the local surface heat flux forcing is only important in a few regions like the subtropical North Atlantic Ocean (Piecuch \& Ponte, 2011). Using the same output, Fukumori and Wang (2013) argued that enhanced rates of regional sea-level rise in the western tropical Pacific Ocean have been due, in part, to anomalous air-sea buoyancy fluxes and heat uptake. With ECCO output over a longer time period (1992 to 2010), Buckley et al. (2015) found that air-sea heat fluxes and Ekman heat transport convergences are responsible for most of the heat content variability on all resolved (monthly to decadal) time scales in the subtropical North Atlantic Ocean, while ocean dynamics drive heat content variability on interannual time scales in the Gulf Stream region and subpolar North Atlantic Ocean. The importance of wind and buoyancy forcings as well as intrabasin and interbasin communication involved in sea-level variability has been demonstrated by Forget and Ponte (2015) over approximately the same time period. Piecuch et al. (2017) analyzed a more recent version of ECCO, discovering that the subpolar North Atlantic Ocean cooling over 2005 to 2015 relative to 1994 to 2004 was the result of a shift in horizontal advection by the gyre. Decadal changes in the subpolar North Atlantic Ocean's circulation have been corroborated using in situ and satellite observations (Palter et al., 2016). Note, that while we focus here on ECCO as a particular example, other state estimates and ocean reanalyses are also available and can be similarly used for many of the studies discussed above.

\subsection{Uncertainties and Future Outlook}

Despite dramatic improvements in the sea-level observing system in recent years, various areas of the ocean are still undersampled and this poses challenges to identifying the steric component of SLC. Although only $\sim 13 \%$ of the ocean heat content resides in regions that are not well-sampled by observations (Desbruyères et al., 2016; Durack et al., 2014), there is considerable bias (Garry et al., 2019) and uncertainty (Llovel et al., 2014) in this number and warming of such regions has been increasing with time (Gleckler et al., 2016). Moreover, there are few observations below 2,000 m depth, in particular (Purkey \& Johnson, 2010), but analyses in regions such as the subtropical South Pacific that have sufficient observations have revealed a 
decade-long intensification in ocean heat transport convergence responsible for heat accumulation (Volkov et al., 2017). To perform more global analyses, satellite altimetry is now being used to estimate the total SLC, with the mass contribution inferred from the GRACE and GRACE-FO satellites. The difference between these two global measurements provides a reliable estimate of the steric contribution which can be independently constrained by the deep Argo program (Johnson et al., 2015; Le Reste et al., 2016). Continuation of these satellite and in situ programs will maintain long-term monitoring of the global sea-level budget and will elucidate the contribution and spatial variation of deep ocean warming (Llovel et al., 2014).

In the last few years several approaches have been developed which estimate ocean heat content and steric SLC using novel methods, potentially providing supplemental information to supplement incomplete in situ measurements. For example, Zhao et al. (2016) demonstrate how satellite observations of internal tides may be used to monitor ocean heat content along internal wave ray paths. This approach exploits the predictability of the tide to measure the travel time of the waves analogous to how acoustic travel time measurements have been used to infer ocean heat content (Dushaw et al., 2009; Munk \& Wunsch, 1979). Tyler et al. (2017) have proposed a method to measure depth-integrated electrical conductivity of the ocean using satellite magnetometers, and Trossman and Tyler (2019) demonstrated that there is a strong relationship between the depth-integrated conductivity and ocean heat content on a wide range of time scales. Fasullo and Gent (2017), motivated by the initial work of Jayne et al. (2003), established a strong relationship between sea surface heights and ocean heat content in many regions of the ocean on monthly to interannual time scales. In practice, these methods remain largely exploratory and, if they prove successful, reconstruction and future monitoring of ocean heat content at every horizontal location could eventually involve either a combination of proxy-based methods or assimilation of the proxies that provide information independent of temperature observations (e.g., Irrgang et al., 2017).

Predictions of future sea level come from a combination of observations, theories, and models with initial conditions given by state estimates such as ECCO or observational climatologies. Multimodel ensembles have been used to demonstrate that the projected patterns of future sea level are similar to the patterns that have been detected by satellite altimetry, which are largest in regions most susceptible to tropical cyclones (Fasullo \& Nerem, 2018). Observations of these patterns with satellite altimetry will continue, but further improvement of the understanding of SLC in coastal regions is needed. Theory suggests that high-resolution knowledge of coastal bathymetry is important to understand how sea level propagates from the open ocean onto shelves (Wise et al., 2018). Furthermore, the distance over which coastal trapping and offshore decay of sea level occurs is largely determined by the baroclinic Rossby deformation radius that can be directly influenced by river discharge on small spatial scales (Piecuch et al., 2018). The resolution of the data that most satellite missions provide could therefore restrict their utility in coastal inundation applications, but ICESat-2 and SWOT, with their improved sampling near the coast, could prove to be valuable supplements to tide gauge observations for such a purpose.

\section{VLM/Solid Earth Deformation}

\subsection{Current State of Knowledge}

VLM in coastal areas can serve to exacerbate the negative impacts of SLC (Brown \& Nicholls, 2015; Mazzotti et al., 2009; Nerem \& Mitchum, 2002; Santamaría-Gómez et al., 2017; Shirzaei \& Bürgmann, 2018; Wöppelmann \& Marcos, 2016). As subsidence can vary strongly with location it is crucial to account for both large-scale and small-scale processes contributing to the VLM budget. This budget is typically divided into GIA and non-GIA components, with the latter including tectonics, and sediment and aquifer-system compaction (Dixon et al., 2006; Frederikse et al., 2019; Meckel et al., 2006). These components impact VLM on different temporal and spatial scales, although it is their combined impact that is relevant for understanding and projecting SLC. Here, we separate the discussion into these two components of VLM. It should be noted that while observations of coastal VLM generally do not distinguish between the two, the focus here is on the specific processes leading to regional SLC.

\subsubsection{GIA-Related Vertical Land Motion}

There has been more than a century of progress in our geophysical and observational understanding of GIA processes. The term GIA encompasses the GRD response of the Earth to the glacial cycles of the last ice age (Gregory et al., 2019; Milne \& Mitrovica, 2008). This adjustment is global in scale, ongoing, and spatially 
variable, and it produces significant changes in sea level that must be removed from tide gauge and altimetry data to estimate the secular rise in GMSL due to modern climate change (e.g., Douglas et al., 2000). In regions once covered by now vanished ice sheets, for example, Canada, northeast United States, and Fennoscandia, or by larger ice sheets (e.g., Greenland), postglacial rebound of the Earth's crust leads to a fall in relative sea level that peaks at present at $\sim 10 \mathrm{~mm} \mathrm{yr}^{-1}$. Surrounding these areas of residual crustal depression are regions of crustal uplift, and the ongoing subsidence of these so-called peripheral bulges (e.g., both coasts of the contiguous United States) leads to an increase in the rate of SLC. It is important to note that while SLC within the "near field" of ice sheets is dominated by VLM, GIA also perturbs the local equipotential that defines the sea surface, and thus also impacts SLC. Outside these near-field regions, changes in the height of the sea surface equipotential dominate crustal elevation changes and the processes impacting SLC include ocean siphoning, the movement of water toward zones of peripheral subsidence, and continental levering, the tilting of the crust (i.e., VLM) at continental margins due to ocean loading (Mitrovica \& Milne, 2002). The net effect of these processes is a far-field fall in sea level of up to $\sim 0.5 \mathrm{~mm} \mathrm{yr}^{-1}$ in relatively low-latitude ocean basins and coastal sites.

The spatial scale of the GIA signal is dependent on the viscosity of the Earth's mantle below the ice sheet, and the above discussion presents the classic view of GIA in response to melting ice sheets in cratonic regions (e.g., Laurentia, Fennoscandia). In regions characterized by anomalously low mantle viscosity (e.g., West Antarctic, Alaska, Patagonia, Iceland), the isostatic adjustment of the Earth to the last glacial cycle (which ended at $\sim 6 \mathrm{ka}$ ) would be complete by the present day, and the GIA response would reflect more recent ice mass changes in response to climate events such as the Little Ice Age (LIA). A case in point is the GIA signal in coastal Alaska (Larsen et al., 2005; Tamisiea et al., 2007). In these cases, the "near field," that is the zone of postglacial rebound and peripheral subsidence, is far more localized to the zone of ice cover.

GIA is generally distinguished from contemporary GRD effects due to ongoing changes in the mass of water stored on land as ice sheets, glaciers, and land water storage. The sea-level patterns associated with the latter have come to be known as "sea-level fingerprints" (Mitrovica et al., 2001). In cratonic regions, this distinction is logical given that the sea-level response to ice mass changes is a simple superposition of an ongoing (and dominantly) viscous signal associated with ice age loading, and an elastic signal due to present-day ice mass flux. However, in low-viscosity regions, the distinction becomes arbitrary given that the sea-level response at present day is sensitive to loading over a continuum of time scales during the last millennium, with viscous relaxation occurring in response to any ice mass change of decadal time scale or longer, and thus the response to changes in ice mass over the past century is not easily distinguished in a physical sense from the response due to changes associated with the LIA. Indeed, recent studies of the Earth response to ice loss in West Antarctic and the Antarctic Peninsula indicate that VLM at some sites can be dominated by viscous effects due to ice loss over the past decades to century (Nield et al., 2014; Zhao et al., 2017; Hay et al., 2017; Barletta et al., 2018).

Sea-level fingerprints computed using elastic Earth models have a distinct and somewhat counterintuitive geometry (Farrell \& Clark, 1976; Mitrovica et al., 2001). Within regions up to $2,000 \mathrm{~km}$ from zones of ice melting, sea level falls as water migrates away from these areas due to the decreasing gravitational pull of the diminished ice sheet. This also impacts SLC through unloading that leads to elastic VLM. The magnitude of the sea-level fall can reach an order of magnitude larger than (and of opposite sign to) the GMSL change associated with the melt event. At greater distances from the ice melting, sea level will rise by progressively greater amounts, and reach a magnitude 30-40\% larger than the GMSL change. In regions of low viscosity, this signal is perturbed by viscous relaxation, and the geometry of the SLC (and VLM) tends move toward the viscoelastic signal associated with classic GIA.

There have been attempts to discriminate between the contributions to SLC or VLM from recent glacier/ice sheet melting and GIA using a combination of GPS and gravimetry measurements (Purcell et al., 2011; Wahr et al., 1995), multiple space-based data sets (e.g., Wahr et al., 2000) and the geometry of the predicted responses (Spada \& Galassi, 2016). Nevertheless, it is clear that the response to the full temporal range of ice mass flux must be considered in state-of-the-art analyses of sea-level data (Frederikse et al., 2018; Hamlington et al., 2018; Hay et al., 2015; Rietbroek et al., 2016). We note that while a theory for predicting gravitationally self-consistent predictions of SLCs in response to ice mass flux is in place (Farrell \& Clark, 1976; Mitrovica \& Milne, 2003), applications of the theory have, with few exceptions, been based 


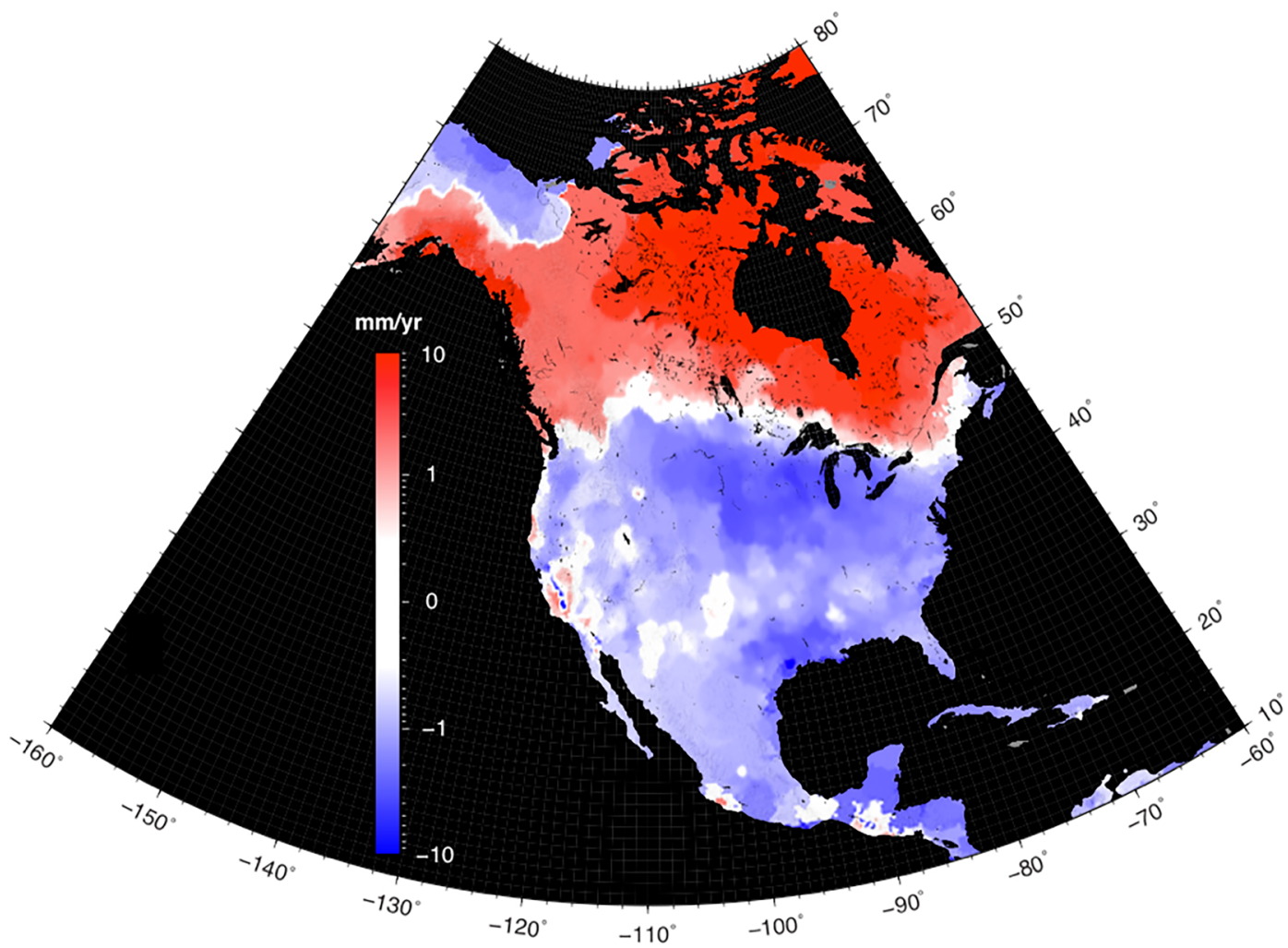

Figure 7. Rates of vertical land motion from GNSS observations made at over 6,000 stations across North America. VLM field is derived using MIDAS velocities in the ITRF 2014 reference frame and GPS imaging interpolation (Blewitt et al., 2018; Hammond et al., 2016). Note that logarithmic color scale is used to highlight both large and small VLM signals, with red representing upward and blue downward motion in $\mathrm{mm} / \mathrm{yr}$.

on Earth models in which viscoelastic structure varies with depth alone. Modeling efforts over the past decade are beginning to consider more realistic models with 3-D variations in Earth structure (e.g., Hay et al., 2017; Latychev et al., 2005; Wu \& van der Wal, 2003).

Space geodetic observations are responsible for tremendous advances in SLC research, including the following: (i) the determination of trends in VLM from terrestrial Global Navigation Satellite System (GNSS) stations located on bedrock (Milne et al., 2001; Blewitt et al.,2016; Figure 7), (ii) estimates of the lowest degree terms in the time varying gravity field from orbital variations of satellites (James \& Ivins, 1995; Mitrovica \& Peltier, 1993; Tosi et al., 2005; Yoder et al., 1983); (iii) improvements in mapping of the Earth's topography, bathymetry, and both the static and time-varying gravity (Farr et al., 2007; Smith \& Sandwell, 1997; Tamisiea et al., 2007); and (iv) the use of Interferometric Synthetic Aperture Radar (InSAR) in constraining VLM (Auriac et al., 2013). Greatly refined models of continental-scale GIA were derived from these three data sets (e.g., Milne et al., 2001; Wahr \& Davis, 2002). Over the past 15 years, the goals and requirements of the GIA community have shifted. The 2002 launch of the GRACE satellite system allowed measurement of time variations in the gravity field at length scales as short as a few hundred $\mathrm{km}$. In addition, the dramatic expansion of global GNSS sites and advances in processing strategies (Blewitt et al., 2016, 2018; King et al., 2012; Wöppelmann \& Marcos, 2016) have provided observations of present-day VLM with unprecedented precision and accuracy (Figure 7).

\subsubsection{Non-GIA-Related VLM}

While GIA dominates active continental-scale VLM, the non-GIA component of VLM results from a diverse set of processes that have widely varying geographic length scales, and these can be difficult to separate from GIA, or from each other. These processes include long-term tectonics motions at plate boundaries (e.g., Burgette et al., 2009; Hammond et al., 2018; Mazzotti et al., 2008; Shimada \& Bock, 1992), as well as coseismic and postseismic deformation (Smith-Konter et al., 2014). Aquifer compaction produces vertical crustal deformation that is unsteady over time in response to changes in drought conditions, climate 
variability, and human water usage. This process has a strong anthropogenic component, as pumping of water from aquifers can cause rapid subsidence (Gatto \& Carbognin, 1981; Ojha et al., 2019). In particular, aquifer depletion drives local-scale poroelastic compaction of aquifer system resulting in a pattern of localized subsidence (Ojha et al., 2019) that is surrounded by regions of uplift due to elastic unloading of the crust (e.g., Amos et al., 2014). Some of these effects contribute to coastal VLM and thus impact SLC (Hammond et al., 2016). Contributions can also arise from sources such as volcanoes, compaction/desiccation of soils, and sediment loading in major river deltas (Brooks et al., 2007; Dixon et al., 2006; Meckel et al., 2006; Miller \& Shirzaei, 2019; Nicholls \& Cazenave, 2010; Stammer et al., 2013). While not only a process impacting VLM, the viscoelastic response to changes in the sediment loading could play a significant role. Sediment transport results in significant mass redistribution in many deltaic and estuarine regions, which in turn result in GRD-induced SLCs. Several recent studies have discussed sediment transport in detail for the Dutch Wadden Sea (e.g., Bing Wang et al., 2018; Fokker et al., 2018; Van der Spek, 2018; Vermeersen et al., 2018), although the direct link between transport and the resulting GRD response has not yet been quantified for this region. Since the last glacial maximum, river routing and sediment yields vary in both space and time. The details, however, are important for present-day VLM modeling at the coast, as the transport of sediment is important to both viscoelastic loading and unloading of the solid earth and hence, subsequent isostatic response. The modeled VLM magnitude at present-day greatly depends on the age of the transport and the spatial contiguousness of high yield of the sediment transport during glacial transition and Holocene time (Ivins et al., 2007). Sediment isostasy produces smaller ( 0.5 to $1.6 \mathrm{~mm} / \mathrm{yr}$ ), but more long-lived, VLM in comparison to sediment compaction (see Karpytchev et al., 2018 and Kuchar et al., 2017 for examples from the Mississippi and Ganges-Brahmaputra Deltas, respectively). An explicit comparison of data-constrained model results for the Po Valley Delta suggests compaction may exceed sediment isostasy there by more than an order of magnitude (see Teatini et al., 2011 and Mey et al., 2016, for recent treatments of regional compaction and sediment isostasy in the Po Valley Delta, respectively).

Disentangling the different spatial-temporal processes that contribute to VLM is challenging. Terrestrial and spaceborne measurement capabilities have been revolutionized in recent decades and offer new and more accurate observations of VLM. GNSS networks now exist on all continents and offer precise ( 2-3 mm or better) daily vertical positions and measurements of VLM rates as precise as a few tenths of a mm $\mathrm{yr}^{-1}$ (Blewitt et al., 2018; Milne et al., 2001). However, GNSS networks are not homogeneously distributed, and in some coastal areas the coverage is sparse, or the data are unavailable. Complementary to GNSS, current-day SAR missions offer global coverage at high resolution, and these images are often available free of charge (e.g., Sentinel-1, ALOS, TerraSAR-X, CosmoSkyMed, and the upcoming NISAR mission). Observations from InSAR are challenging in coastal regions due to the presence of vegetation and wetlands, which are responsible for a degraded interferometric signal (e.g., Zebker \& Villasenor, 1992). The superposition of atmospheric propagation delays from ionospheric and tropospheric effects (e.g., Bekaert et al., 2015 Shirzaei \& Bürgmann, 2012) also contribute spatially correlated errors that can be difficult to separate from localized deformation signals. In part, these problems are mitigated by the following: the consistent and frequent revisit time of ongoing SAR missions (as short as 6 days for Sentinel-1 and 12 days for NISAR); longer wavelength systems that are less sensitive to vegetation changes; correction models informed by external data sets (e.g., Bekaert et al., 2015; Doin et al., 2009); and the application of advanced time-series InSAR processing methods (e.g., Ferretti et al., 2011; Hooper et al., 2012; Shirzaei et al., 2013; Tymofyeyeva \& Fialko, 2015).

\subsection{Uncertainties and Future Outlook}

One of the new challenges for GIA modeling is to integrate diverse data (e.g., relative sea-level markers, GNSS, secular gravity rates, and tide gauge records) into a properly weighted cost function for testing of global and regional models of GIA, and recent and present-day mass changes, and subsequently providing associated uncertainty estimates. This requires dealing with data sets that range in time from as long as 150,000 years (when initializing late Quaternary ice histories) to as short as 5 years or less (when analyzing GNSS-determined VLM). Furthermore, a main goal is to project future SLC using coupled models that fully account for viscoelastic mantle flow, gravitationally self-consistent SLCs, and detailed ice histories during the past glacial cycle with dynamically and thermally realistic ice sheet models (Adhikari et al., 2014; Gomez et al., 2012, 2013, 2018; Konrad et al., 2015) that account for 3-D variability in mantle structure (Gomez et al., 2018). 
Table 2

High-Frequency Sea-Level Phenomena

\begin{tabular}{ll}
\hline Phenomenon & \multicolumn{1}{c}{ Definition } \\
\hline Astronomical tides & fluid motion caused by the predictable orbits of the Earth and Moon \\
Storm surge & large-scale motion generated by atmospheric weather systems such as hurricanes, typhoons, and extra-tropical cyclones \\
Wave setup & increased coastal sea level generated by offshore breaking waves \\
Wind waves & waves, sometimes large, generated by wind \\
Ocean Swell & long-period waves generated by remote wind or storms \\
Wave run-up & wave-driven motion at the shoreline, relevant to erosion and overtopping of coastal defenses \\
\hline
\end{tabular}

InSAR and GNSS are complementary in that GNSS provides long-term stability, vector displacements, and better temporal coverage compared to InSAR, which provides high-resolution spatial coverage. Results from one technique can be directly applicable to the other. For instance, over large scales, InSAR deformation data need to be combined with GNSS observations to precisely estimate long-wavelength deformation signals, while GNSS observations can be used to calculate atmospheric corrections for InSAR. The InSAR measurements of surface deformation are provided in a local reference frame whereas the GNSS observations are provided in a global reference frame (i.e., with respect to the Earth's center of mass). Thus, GNSS observation can be used to transform InSAR measurements to a global reference frame suitable for studies of SLC. InSAR measurements are especially well suited to identifying localized sources of deformation such as subsidence and compaction of sediments and aquifers.

Recent studies (Yu et al., 2017, 2018) have developed correction models that combine estimates of GNSS tropospheric delay and high-resolution weather data to correct SAR interferograms for contributions from tropospheric delay due to variations in water vapor, temperature, and pressure during the two image acquisitions. Despite their success in some cases, these models have limited spatial and temporal resolution imposed by the sparse data sets used to constrain them.

The next obvious step in such efforts is to combine the data from multi SAR sensors with GNSS observations for reliable estimation of the long- and short-wavelength components of the VLM at tens of meter resolution within a global reference frame (Ojha et al., 2018; Shirzaei \& Bürgmann, 2018). Further work is necessary to obtain the full covariance matrix of the VLM rate as a function of various sources of noise. Observations of the present-day VLM rate and associated uncertainties also need to be projected forward to be compared with SLC forecasts used in flood resilience planning that are of interest to stakeholders (Shirzaei \& Bürgmann, 2018). Excluding regions of low mantle viscosity (e.g., Iceland, Alaska, Patagonia, West Antarctica), the GIA contributions in VLM are quasi-steady over several centuries, and thus a linear extrapolation might be suitable (Kopp et al., 2016). However, in those low-viscosity regions, mass changes in the present day and over the last few decades to centuries also need to be modeled to capture viscoelastic effects that will contribute to future projections. VLM contributions due to groundwater and hydrocarbon extraction are highly nonlinear, and the residual compaction of the porous layers due to past production may last decades to centuries (Galloway \& Burbey, 2011; Holzer \& Galloway, 2005; Miller et al., 2017). Additionally, VLM can also occur in response to natural compaction due to sediment loading at rates between 0.1 to $1 \mathrm{~mm} \mathrm{yr}^{-1}$, which can last for $10^{5}$ years (Kooi \& De Vries, 1998). Mechanical models accounting for the underlying physics of the VLM process are required to accurately project VLM into the future.

\section{Contributions From High-Frequency Water Level Variability}

\subsection{Current State of Knowledge}

High-frequency variations in sea level include those associated with astronomic tides, storm surges, and ocean waves (swell and wind waves) leading to wave setup and/or wave run-up. Societally relevant extreme sea levels result from the combination and interaction of these phenomena with the lower-frequency processes discussed in previous sections. High-frequency sea-level variability can cause impacts such as flooding, coastal erosion and sediment transport, and destruction of shoreline defenses. Because of the wide ranging economic and environmental consequences of such events, there are significant efforts to understand the superposition of the different sea-level components, and how they are modulated by climate change and variability, individually and in combination. Table 2 lists the different phenomena discussed 
Table 3

Impacts of Extreme Coastal Water Level

\begin{tabular}{lc}
\hline Impact & Main contributors \\
\hline Destruction of shoreline defenses & Waves, swell, surge \\
Coastal erosion & Waves, swell, surge \\
Altered estuarine dynamics and morphodynamics & Tides \\
High tide flooding & Tides \\
Catastrophic flooding & Any and all factors combined \\
\hline
\end{tabular}

in this section, and Table 3 highlights some of the impacts arising from extreme sea levels. The significance of impacts is highly variable and depends on detailed site characteristics and the magnitude, duration, and frequency of the sea-level extreme. Impacts can arise from both particularly strong storms, as well as indirect and cumulative effects of lesser-extreme high tide flooding (Sweet et al., 2018; Wahl et al., 2018).

Knowledge of high-frequency sea level is derived from different observing systems. Tide gauges provide the longest records of high-frequency sea-level variability (Woodworth et al., 2017), but they are not intended to monitor waves and wave run-up. Wind waves and swell are monitored by the global network of-mostly coastal - wave buoys (Hemer et al., 2012), and, since 1993, satellite radar altimeters have routinely measured significant wave height (Ray \& Beckley, 2012). Observations of wave run-up are not widespread but are generally conducted for studies of coastal morphodynamics (Suanez et al., 2015) or inundation (Gallien et al., 2014).

It is useful to distinguish between statistical and dynamical descriptions of sea-level variability, which serve complementary roles in describing, explaining, and forecasting sea-level variability and extremes (Lowe et al., 2010). Statistical descriptions are frequently provided in the form of parametric extreme value distributions for sea-level exceedance probabilities and return times (Buchanan et al., 2016; Wahl et al.,2017), which may be modulated by low-frequency regional sea level (Muis et al., 2018) and other processes (Barnard et al., 2015; Wahl \& Chambers, 2015). The classical statistical approach typically requires long records of high-frequency sea-level observations. In a recent study, Calafat and Marcos (2020) combined these observations with a Bayesian hierarchical model to compute the characteristics of sea-level extremes for unobserved coastlines. Dynamical descriptions, through hydrodynamic models, are increasingly being used to model high-frequency sea-level events resulting from atmospheric forcing (Muis et al., 2016), and they may be combined with climate change scenarios to predict future sea-level extremes (Vousdoukas et al., 2018).

One general challenge in the study of high-frequency variability is the lack of global data sets with sufficient duration to validate either dynamic or statistical models of different high-frequency sea-level components (Dangendorf et al., 2016; Lowe et al., 2010). Recent work highlights the significance of the shape of extreme value distributions and the representation of uncertainty in statistical storm surge models when assessing sea-level impacts and adaptation (Wahl et al., 2017); the need to establish consistent elevation thresholds for impact evaluation (Sweet et al., 2018); and the importance of reevaluating risk assessments as new data and analysis methods become available (Hunter et al., 2017). Site-specific and regional studies are necessary since high-frequency processes depend on both small-scale geographical features and regional meteorology (Lowe et al., 2010).

Analyses of historical data have found that trends and interdecadal variability of extreme sea level are generally driven by the trend in mean sea level and large-scale climate processes such as ENSO, rather than by trends in high-frequency variability (Mawdsley et al., 2015; Mawdsley \& Haigh, 2016; Menéndez \& Woodworth, 2010; Merrifield et al., 2013; Muis et al., 2018; Wahl \& Chambers, 2015). There are, however, some sites where regional changes in storm surge frequency or intensity (Reed et al., 2015; Talke et al., 2014), swell-driven wave setup (Melet et al., 2018), and coastal morphology (de Vet et al., 2017) have impacted trends in extreme sea level. Widespread increases in the frequency of minor flooding have occurred, relative to the recent historical average (Figure 8).

Projections of extreme sea levels have been conducted which include the combined effects of mean sea level, tides, wind waves, and storm surges. Tropical regions, with rather narrow (short-tailed) extreme sea-level distributions today, will experience the largest increases in flooding frequency (Vitousek et al., 2017). Beach erosion and morphodynamics are controlled by wave direction and energy, which are attributes of 


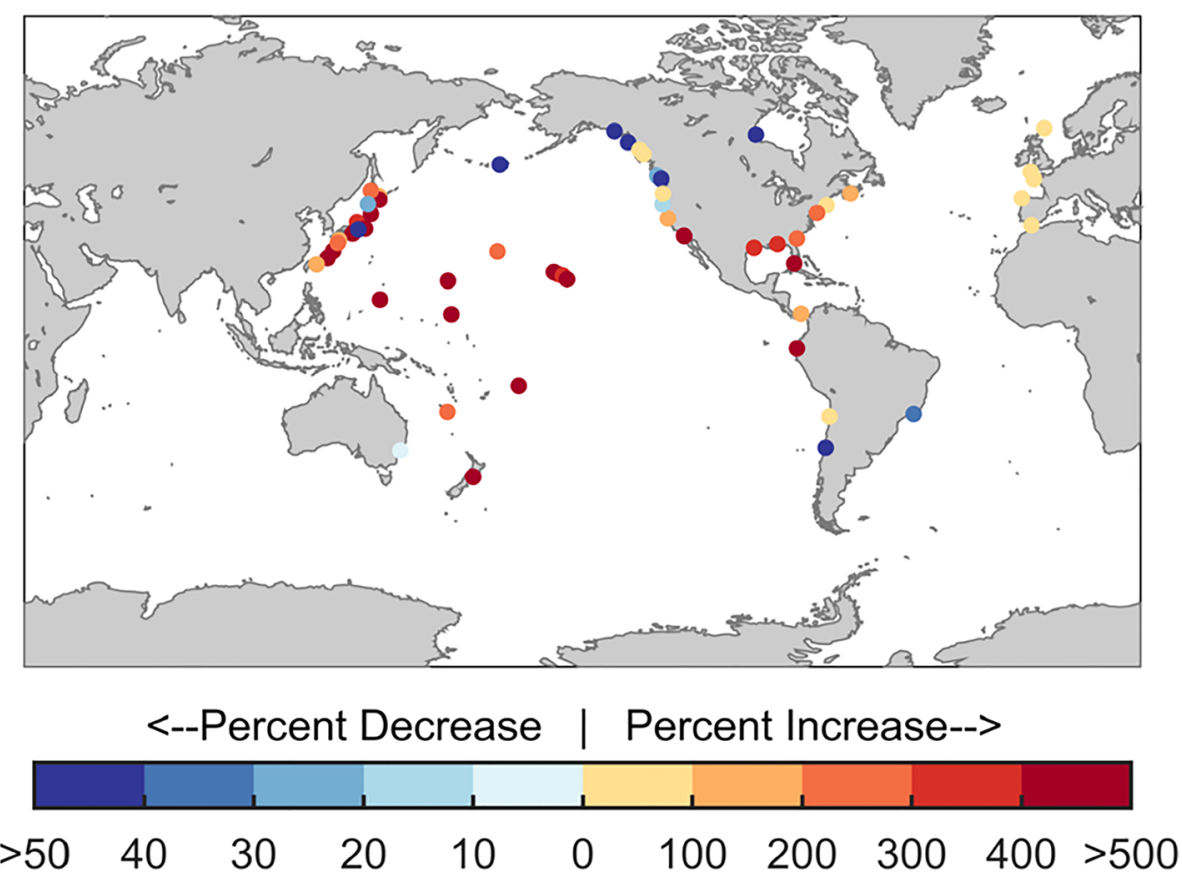

Figure 8. Change in current average annual minor tidal flood frequency relative to 1960-1980 average.

high-frequency sea-level variability. If extreme El Niño and La Niña events become more frequent in the next century, as has been predicted, then populated regions around the Pacific will be increasingly exposed to both extreme coastal erosion and flooding, independent of sea-level rise (Barnard et al., 2015). Detailed regional projections point to the growth of lesser-extreme events, so-called "high tide flooding," becoming more common in the next century along the shoreline of the United States and its territories (Dahl et al., 2017; Ray \& Foster, 2016; Sweet et al., 2018; Sweet \& Park, 2014), throughout the tropical Pacific (Stephens \& Ramsay, 2014), in the South China Sea (Devlin et al., 2017) and, probably, worldwide (Moftakhari et al., 2018). Forecasts of tide-related flooding are sensitive to the underlying mean SLC scenarios, and accurate prediction requires accounting for changes in the tides themselves (Mawdsley et al., 2015; Woodworth, 2010) and VLM (Karegar et al., 2017). Changes in tides have been discussed in detail in Haigh et al. (2019).

The above discussion has focused on the contribution of high-frequency sea-level variability to extreme coastal sea level, but nonlinear coupling of high-frequency sea level to other processes is important, as well. Recent work has pointed out that the prediction of future cryospheric contributions to SLC must incorporate dynamical feedbacks between high-frequency tidal variability and ice sheet behavior (Padman et al., 2018). Moreover, changes in mean sea level will eventually lead to potentially-significant changes in the tides (Pickering \& Alford, 2012; Schindelegger et al., 2018; Wilmes et al., 2017). Nonlinear feedback between waves and water depth (Arns et al., 2017), tides and morphology (de Vet et al., 2017), and fluvial and ocean processes (Moftakhari et al., 2017) are important at some sites.

\subsection{Uncertainties and Future Outlook}

Key uncertainties concerning high-frequency sea-level extremes arise from the lack of measurements of historical water level at the locations and scales needed to define the sea-level distribution, in particular, in the tails, a fundamental quantity for assessing change and validating models of present conditions. Present studies make the case that trends in sea-level extremes will be driven by the long-term (but difficult to measure locally) trends in mean sea level, but improvements in the representation of geodetically referenced sea level in climate models, and their representation of factors such as projected storm tracks and intensity, will lead to a better understanding of the uncertainty or plausible range of sea-level extremes at any particular location (Garner et al., 2017). The potential for coupling between a multitude of processes, outlined above, at small scales can lead to considerable uncertainty. Finally, changing 
coastal infrastructure and VLM may be associated with uncertain changes in inundation extent for a given extreme event, with profound consequences for the associated societal impacts. The latter are also affected by socio-economic factors.

Future work relevant to high-frequency sea level should continue to accumulate geodetically-referenced sealevel data to identify and attribute sea-level extremes. Fundamental research concerning the connection between sea level at the coast and sea level offshore (past the continental shelf) should be a priority (Lobeto et al., 2018; Wise et al., 2018). Improvements in the representation of high-frequency processes in ocean and cryosphere models will contribute to forecasting future climate (Padman et al., 2018).

Satellite altimeter missions have provided foundational data for the description of sea-level variability since 1992. These data have enabled the development of very accurate hydrodynamic models for the ocean tide (Stammer et al., 2014), and, by inference, improvements to hydrodynamic storm surge models, since both tides and surge are distinguished primarily by the nature of the forcing rather than their dynamics, per se (Carrère \& Lyard, 2003). Recent developments in delay-Doppler techniques (Wingham et al., 2006) and Ka-band altimetry (Bonnefond et al., 2018) are enabling water level measurements at smaller scales than conventional nadir altimetry. Studies that use altimetry to assess extreme sea levels (Lobeto et al., 2018) make extensive use of coastal tide gauge records to correlate observations at the scale of the radar footprint with sea-level extremes at the coastline. Longer time series and higher spatial resolution will lead to the increasing use of altimetry to study sea-level extremes in the future.

Two future satellite missions will contribute to our knowledge of the coastal impacts of high-frequency sealevel fluctuations. The SWOT mission will provide high-resolution snapshots of the coastal ocean and inland waterways (Fu et al., 2009) and is scheduled for launch in 2021. The repeat period of the orbit, 21 days, is too long to temporally resolve the phenomena discussed here, but the unprecedented spatial resolution (200 $\mathrm{m})$ and accuracy of the observations will undoubtedly stimulate progress in coupled modeling of tides, surges, and lower-frequency phenomena (Turki et al., 2015). NISAR is a joint NASA and Indian Space Research Organization synthetic aperture radar mission scheduled to launch in 2022. NISAR will provide all-weather, day/night imaging the Earth repeated 4-6 times per month, resolving coastal inundation with a horizontal resolution of 3 to $10 \mathrm{~m}$ (Amelung et al., 2018). It will provide crucial data for validating inundation models, and its data, when linked to extreme sea-level information from tide gauges and satellite, should prove useful for improving digital elevation models and hydrodynamic flood models.

\section{Near-Term Outlook of Regional Relative Sea-Level Understanding}

Despite gaps in our understanding, efforts have been made to project future SLC on regional spatial scales. Recent reviews have summarized these approaches in detail (e.g., Garner et al., 2018; Horton et al., 2018) and the interested reader is referred to these articles. The extent to which the various contributions to sea level and their statistical dependencies can be combined to provide a complete and accurate assessment of future regional SLC, however, is dependent on the current uncertainties associated with each of these signals. Projections of future regional SLCs have mostly focused on physical processes related to ice-mass loss and ocean dynamics. When combined with estimates of GIA, projections of future regional SLC are then created. Next to the uncertainties in these large-scale changes, two assumptions are made that affect the usefulness of this approach. First, the role of ocean dynamics on local coastal sea level is not well resolved in the coarse-resolution Earth system models that are used to project the regional changes. Decoupling between the coastal zone and open ocean acts on a wide range of time scales up to multidecadal fluctuations (Woodworth et al., 2019). Improvements in understanding the linkage between coastal sea level and ocean dynamics, and increased model resolutions, are important in establishing this link and are a key requirement for understanding future changes in coastal sea level and its variability on a wide range of time scales. Second, local VLM that is not related to GIA or contemporary GRD effects is often not incorporated into these projections. Some studies (e.g., Kopp et al., 2014) use and extrapolate contemporary rates of local VLM to project the role of VLM in future sea level. Since for many coastal locations, including many megacities, VLM is currently the dominant driver of local SLC, a thorough understanding and accompanied forecasting of local VLM is crucial in projecting future changes. Both issues depend on the local situation, and are therefore challenging to assess in global studies. Nevertheless, combining knowledge of global processes and local effects is necessary to improve local sea-level projections. 
One of the primary goals of this paper has been to identify the areas of uncertainty in each of the processes contributing to regional SLC. While we have discussed each of these uncertainties in the material above, it is important to review how some of these uncertainties may be reduced in the near future. In particular, we highlight where recent and future observation systems - particularly satellite based-can and will be used to reduce limitations and uncertainties, and subsequently improve the quality of future assessments of SLC.

1. ICESat-2

Following on from ICESat and Operation IceBridge, ICESat-2 will not only extend the record of regional glacier mass change, it will also provide increased spatial resolution of glaciers. Technological advances on ICESat-2 allow it to continuously collect high-precision and dense, along-track measurements with a narrow illumination footprint (Neumann et al., 2019) that is well suited to measure glacier height changes in areas of complex topography (Smith et al., 2019). These fine-scale measurements provide the opportunity to resolve several gaps in our understanding of future ice sheet and glacier mass change that will impact regional sea level. Furthermore, ICESat-2's narrow footprint and ability to measure near-shore bathymetry could prove to be valuable for terrestrial water investigations and coastal inundation applications when these data are analyzed in tandem with tide gauge records in allowing for near-coast measurements of sea level.

\section{GRACE-FO}

With the launch of GRACE-FO, the record of mass change across the globe that began with GRACE will be extended (albeit with a 1-year data gap between the two missions). Extending the time series of ice sheet mass change, glacier mass change, and terrestrial water storage is critical for separating the natural variability from the long-term anthropogenic trend, and also for evaluating projections of future sea level.

\section{Jason-CS/Sentinel-6}

Recent studies have sought to understand the extent to which the anthropogenic pattern of regional SLC is emerging from the natural climate variability using the 25-year altimetry record (Fasullo \& Nerem, 2018; Royston et al., 2018; Hamlington et al., 2019). Such studies underscore the importance of the continuity of the observational records, as many of the sources of uncertainty discussed above can be reduced through ongoing monitoring and lengthening of the data records that are currently available. The Jason Continuity of Service (Jason-CS) mission on the Sentinel-6 spacecraft will launch in 2020, and will extend the continuous record of altimeter-measured SLC into its fourth decade. With this long record, improved constraints the emergence of the forced or anthropogenic trends in sea level can be obtained, providing an opportunity to evaluate sea-level projections and improve model-based estimates, while allowing the monitoring of ongoing changes in sea level across a range of time and space scales.

\section{NISAR}

When launched in 2022, NISAR will provide all-weather, day/night imaging the Earth repeated 4-6 times per month, resolving coastal inundation with a horizontal resolution of 3 to $10 \mathrm{~m}$. NISAR will be immensely valuable for monitoring changes in Antarctic and Greenland ice sheet flow. As the only left-looking SAR mission NISAR will be particularly valuable for observing changes in the southernmost regions where little information on flow variability is available. These observations will provide crucial data for validating inundation models. Furthermore, NISAR data, when linked to extreme sea-level information from tide gauges and satellite, should prove useful for improving digital elevation models and hydrodynamic flood models. NISAR will also allow for new estimates of coastal VLM at high resolutions.

\section{SWOT}

Continued improvements in the resolution and process representation of land-surface models will allow for better understanding of changing regional hydrology, including the inclusion of human activities and water consumption. These model developments will be supported by SWOT, which will provide the first observational estimate of global continental river discharge, helping to deepen the present understanding of global and regional water cycles. Additionally, SWOT will provide near-coast measurements of sea level that will fill the gap between the open-ocean measurements of altimetry and the coastal measurements of tide gauges. 


\section{In Situ Observations}

In addition to the satellite systems discussed above, in situ observations of the processes contributing to SLC continue to play an essential role, both in serving to validate measurements made remotely and also in complementing the space-based network by observing processes difficult to measure remotely. In the coming years, the deep Argo profiling float program will continue to expand, providing more measurements at depth that are critical to our understanding of the global and regional sea-level budgets, among other processes. Additionally, tide gauges continue to provide direct measurements of SLC at many locations around the globe. Tide gauges allow for studies of the connection between the open ocean and coastal zone, provide measurements of SLC and VLM when colocated with GNSS, and measure the higher-frequency sea-level variability discussed in section 8 . Efforts to increase the availability of tide gauge data and provide improved data sets to users are underway. As an example, the Global Extreme Sea Level Analysis (GESLA) project is in its third iteration, providing data on extreme sea levels at an increasing number of tide gauges around the globe (Woodworth et al., 2017).

\section{Summary}

Changes in GMSL provide an integrative measure of the state of the climate system, encompassing both the ocean and cryosphere and may be viewed as an important indicator of what is currently happening to the climate in the present and what may happen in the future. While an increase in GMSL portends an increase in sea level of some magnitude along the world's coastlines, the response on regional levels is not uniform. Water that is added to the ocean from land will not be distributed evenly everywhere (sections 3-5) and changes in ocean dynamics add to the regional variability in sea-level rise (section 6). Using observations from tide gauges and satellite altimetry, the extent of the spatial variability in the rate of sea-level rise can be understood. With the recent improved understanding of GRD effects on sea level, and the suite of VLM effects outlined here, it has become clear that the use of a single global rate to describe sea level around the globe is problematic, and improved assessment of sea-level rise on regional levels is required from a planning perspective.

Over the past century, coastal sea levels have risen over the majority of the globe. The effect of increasing sea level relative to land is a significant reduction in the elevation gap between typical high tides and a threshold elevation at which flooding begins (Sweet et al., 2018). Coastal communities were established with this gap in mind, recognizing flooding might occur under the most extreme of conditions. Recent reports (e.g., Sweet et al., 2017, 2018) have detailed the rapidly declining gap along the coastlines of the world, and the accelerated effect this has had on flood frequencies in many coastal locations. One important implication of these analyses is that the narrowed gap between high tide and flooding conditions can now be overcome by sea-level variability on a range of time scales. Subsequently, from a decision-making perspective, improved projections of future regional SLC are needed over a variety of time horizons, not simply the longest.

As discussed here, sea level varies on time scales from short-term (section 8), to seasonal-to-decadal (sections 5 and 6) or longer (sections 3-5). When considered in tandem with the movement of land relative to the ocean (section 7), contributions to sea level at each of these time scales can combine constructively, increasing sea levels and high-tide flood frequencies over both the short and long terms. The gap described above is known in many locations, and time horizons can be generated over which high-tide flood frequency will begin to increase rapidly. When considering only the long-term trend, this time horizon is usually found to be on the order of decades. However, when combined with the other contributors to sea-level variability, it is highly likely that in the short term (on the order of years) the cumulative effect of high-tide flooding will extend beyond "nuisance" levels and becomes too frequent for business as usual in coastal areas. As such, there is a strong need for improved information regarding future sea-level rise across a range of time scales.

While understanding the long-term contributions from melting glaciers and ice-sheets is essential, so too is understanding, quantifying, and possibly predicting the variability that will occur on seasonal to decadal time scales. Recent studies suggest that these contributors are becoming distinguishable with the records available (e.g., Fasullo \& Nerem, 2018; Nerem et al., 2018). With the observations that are available-or will become available soon-coupled with improved data analysis and modeling efforts, our understanding of future regional SLC will continue to advance in the coming years. Knowing that planning efforts are underway and that sea-level rise is already impacting many parts of the world's coastlines, it is worth taking 
inventory of the current state of understanding and clearly identifying areas of uncertainty that are impacting our ability to provide complete, accurate, and actionable information at the coast. Such assessments should be undertaken frequently to update relevant information in light of new science results, and to assist those tasked with translating current scientific understanding into plans that can be put into action at the coast.

\section{Competing Interests}

The authors declare no competing interests.

\section{Materials and Correspondence}

All materials and correspondence requests can be directed to B. D. H. at benjamin.d.hamlington@jpl. nasa.gov

\section{Data Availability Statement}

Gridded Surface Height Anomalies Version 1801. Ver. 1801 available from NASA JPL PO.DAAC, CA, USA (https://doi.org/10.5067/SLREF-CDRV1). Data are also available through Wiese et al. (2017).

\section{References}

The research was carried out in part at the Jet Propulsion Laboratory, California Institute of Technology, under a contract with the National Aeronautics and Space Administration. The authors acknowledge support from the National Aeronautics and Space Administration under Grants 80NSSC17K0565, 80NSSC170567, 80NSSC17K0566, 80NSSC17K0564, and NNX17AB27G. A. A. acknowledges support under GRACE/GRACEFO Science Team Grant (NNH15ZDA001N-GRACE). T. W. acknowledges support by the National Aeronautics and Space Administration (NASA) under the New (Early Career) Investigator Program in Earth Science (Grant: 80NSSC18K0743). C. G. P was supported by the J. Lamar Worzel Assistant Scientist Fund and the Penzance Endowed Fund in Support of Assistant Scientists at the Woods Hole Oceanographic Institution.

Arns, A., Dangendorf, S., Jensen, J., Talke, S., Bender, J., \& Pattiaratchi, C. (2017). Sea-level rise induced amplification of coastal protection
Abraham, J. P., Baringer, M., Bindoff, N. L., Boyer, T., Cheng, L. J., Church, J. A., et al. (2013). A review of global ocean temperature observations: Implications for ocean heat content estimates and climate change. Reviews of Geophysics, 51, 450-483. https://doi.org/ 10.1002/rog. 20022

Adhikari, S., \& Ivins, E. R. (2016). Climate-driven polar motion: 2003-2015. Science Advances, 2, e1501693. https://doi.org/10.1126/ sciadv. 1501693

Adhikari, S., Ivins, E. R., \& Larour, E. (2016). ISSM-SESAW v1. 0: Mesh-based computation of gravitationally consistent sea-level and geodetic signatures caused by cryosphere and climate driven mass change. Geoscientific Model Development, 9(3), 1087-1109. https://doi. org/10.5194/gmd-9-1087-2016

Adhikari, S., Ivins, E. R., Larour, E., Seroussi, H., Morlighem, M., \& Nowicki, S. (2014). Future Antarctic bed topography and its implications for ice sheet dynamics. Solid Earth, 5(1), 569-584. https://doi.org/10.5194/se-5-569-2014

Adhikari, S., \& Marshall, S. J. (2013). Influence of high-order mechanics on simulation of glacier response to climate change: Insights from Haig Glacier, Canadian Rocky Mountains. The Cryosphere, 7(1), 1527-1541. https://doi.org/10.5194/tc-7-1527-2013

Agosta, C., Amory, C., Kittel, C., Orsi, A., Favier, V., Gallée, H., et al. (2019). Estimation of the Antarctic surface mass balance using the regional climate model MAR (1979-2015) and identification of dominant processes. The Cryosphere, 13(1), 281-296. https://doi.org/ $10.5194 /$ tc-13-281-2019

Al-Ibadi, M., Sprick, J., Athinarapu, S., Berger, V., Stumpf, T., Paden, J., et al. (2018, April). Crossover analysis and automated layer-tracking assessment of the extracted DEM of the basal topography of the canadian arctic archipelago ice-cap. In 2018 IEEE radar conference (RadarConf18) (0862-0867). New York, NY: IEEE. https://doi.org/10.1109/radar.2018.8378673

Amos, C. B., Audet, P., Hammond, W. C., Bürgmann, R., Johanson, I. A., \& Blewitt, G. (2014). Uplift and seismicity driven by groundwater depletion in central California. Nature, 509(7501), 483. https://doi.org/10.1038/nature13275 design heights. Scientific Reports, 7, 40171. https://doi.org/10.1038/srep40171

Arthern, R. J., Hindmarsh, R. C., \& Williams, C. R. (2015). Flow speed within the Antarctic ice sheet and its controls inferred from satellite observations. Journal of Geophysical Research: Earth Surface, 120, 1171-1188. https://doi.org/10.1002/2014jf003239

Aschwanden, A., Fahnestock, M. A., \& Truffer, M. (2016). Complex Greenland outlet glacier flow captured. Nature Communications, 7, 10524. https://doi.org/10.1038/ncomms10524

Auriac, A., Spaans, K. H., Sigmundsson, F., Hooper, A., Schmidt, P., \& Lund, B. (2013). Iceland rising: Solid earth response to ice retreat inferred from satellite radar interferometry and visocelastic modeling. Journal of Geophysical Research: Solid Earth, 118, 1331-1344. https://doi.org/10.1002/jgrb.50082

Bakker, A. M., Louchard, D., \& Keller, K. (2017). Sources and implications of deep uncertainties surrounding sea-level projections. Climatic Change, 140(3-4), 339-347. https://doi.org/10.1007/s10584-016-1864-1

Balmaseda, M. A., Trenberth, K. E., \& Källén, E. (2013). Distinctive climate signals in reanalysis of global ocean heat content. Geophysical Research Letters, 40, 1754-1759. https://doi.org/10.1002/grl.50382

Bamber, J. L., \& Aspinall, W. P. (2013). An expert judgement assessment of future sea level rise from the ice sheets. Nature Climate Change, 3, (4), 424-427. https://doi.org/10.1038/nclimate1778

Bamber, J. L., Oppenheimer, M., Kopp, R. E., Aspinall, W. P., \& Cooke, R. M. (2019). Ice sheet contributions to future sea-level rise from structured expert judgment. Proceedings of the National Academy of Sciences, 116, (23), 11195-11200. https://doi.org/10.1073/ pnas. 1817205116

Bamber, J. L., Westaway, R. M., Marzeion, B., \& Wouters, B. (2018). The land ice contribution to sea level during the satellite era. Environmental Research Letters, 13(6), 063008. https://doi.org/10.1088/1748-9326/aadb2c

Barletta, V. R., Bevis, M., Smith, B. E., Wilson, T., Brown, A., Bordoni, A., et al. (2018). Observed rapid bedrock uplift in Amundsen Sea Embayment promotes ice-sheet stability. Science, 360, (6395), 1335-1339. https://doi.org/10.1126/science.aao1447

Barnard, P. L., Short, A. D., Harley, M. D., Splinter, K. D., Vitousek, S., Turner, I. L., et al. (2015). Coastal vulnerability across the Pacific dominated by El Nino/Southern oscillation. Nature Geoscience, 8(10), 801-807. https://doi.org/10.1038/ngeo2539

Bekaert, D. P. S., Walters, R. J., Wright, T. J., Hooper, A. J., \& Parker, D. J. (2015). Statistical comparison of InSAR tropospheric correction techniques. Remote Sensing of Environment, 170, 40-47. https://doi.org/10.1016/j.rse.2015.08.035 
Biancamaria, S., Lettenmaier, D. P., \& Pavelsky, T. M. (2016). The SWOT mission and its capabilities for land hydrology. Remote Sensing and Water Resources, 117-147. https://doi.org/10.1007/978-3-319-32449-4_6

Blazquez, A., Meyssignac, B., Lemoine, J. M., Berthier, E., Ribes, A., \& Cazenave, A. (2018). Exploring the uncertainty in GRACE estimates of the mass redistributions at the Earth surface: Implications for the global water and sea-level budgets. Geophysical Journal International, 215(1), 415-430. https://doi.org/10.1093/gji/ggy293

Blewitt, G., Hammond, W. C., \& Kreemer, C. (2018). Harnessing the GPS data explosion for interdisciplinary science. Eos, 99. https://doi. org/10.1029/2018EO104623

Blewitt, G., Kreemer, C., Hammond, W. C., \& Gazeaux, J. (2016). MIDAS robust trend estimator for accurate GPS station velocities without step detection. Journal of Geophysical Research: Solid Earth, 121, 2054-2068. https://doi.org/10.1002/2015jb012552

Bliss, A., Hock, R., \& Radić, V. (2014). Global response of glacier runoff to twenty-first century climate change. Journal of Geophysical Research: Earth Surface, 119, 717-730. https://doi.org/10.1002/2013jf002931

Bondzio, J. H., Morlighem, M., Seroussi, H., Wood, M. H., \& Mouginot, J. (2018). Control of ocean temperature on Jakobshavn Isbræ's present and future mass loss. Geophysical Research Letters, 45, 12-912. https://doi.org/10.1029/2018gl079827

Bonnefond, P., Verron, J., Aublanc, J., Babu, K., Bergé-Nguyen, M., Cancet, M., et al. (2018). The benefits of the Ka-Band as evidenced from the SARAL/AltiKa altimetric mission: Quality assessment and unique characteristics of AltiKa data. Remote Sensing, 10(2), 83. https:// doi.org/10.3390/rs10010083

Borstad, C. P., Khazendar, A., Larour, E., Morlighem, M., Rignot, E., Schodlok, M. P., \& Seroussi, H. (2012). A damage mechanics assessment of the Larsen B ice shelf prior to collapse: Toward a physically-based calving law. Geophysical Research Letters, 39. L18502 https://doi.org/10.1029/2012gl053317

Boyer, T., Domingues, C. M., Good, S. A., Johnson, G. C., Lyman, J. M., Ishii, M., et al. (2016). Sensitivity of global upper-ocean heat content estimates to mapping methods, XBT bias corrections, and baseline climatologies. Journal of Climate, 29(13), 4817-4842. https://doi.org/ 10.1175/JCLI-D-15-0801.1

Brisbourne, A. M., Smith, A. M., Vaughan, D. G., King, E. C., Davies, D., Bingham, R. G., et al. (2017). Bed conditions of Pine Island Glacier, West Antarctica. Journal of Geophysical Research: Earth Surface, 122, 419-433. https://doi.org/10.1002/2016JF004033

Bromirski, P. D., Miller, A. J., Flick, R. E., \& Auad, G. (2011). Dynamical suppression of sea-level rise along the Pacific coast of North America: Indications for imminent acceleration. Journal of Geophysical Research, 116, C07005 https://doi.org/10.1029/ 2010jc006759

Bronselaer, B., Winton, M., Griffies, S. M., Hurlin, W. J., Rodgers, K. B., Sergienko, O. V., et al. (2018). Change in future climate due to Antarctic meltwater. Nature, 564(7734), 53-58. https://doi.org/10.1038/s41586-018-0712-z

Brooks, B. A., Merrifield, M. A., Foster, J., Werner, C. L., Gomez, F., Bevis, M., \& Gill, S. (2007). Space geodetic determination of spatial variability in relative sea-level change, Los Angeles basin. Geophysical Research Letters, 34, L01611. https://doi.org/10.1029/ $2006 \mathrm{gl028171}$

Brown, S., \& Nicholls, R. J. (2015). Subsidence and human influences in mega deltas: The case of the Ganges-Brahmaputra-Meghna. Science of the Total Environment, 527, 362-374. https://doi.org/10.1016/j.scitotenv.2015.04.124

Brun, F., Berthier, E., Wagnon, P., Kääb, A., \& Treichler, D. (2017). A spatially resolved estimate of High Mountain Asia glacier mass balances from 2000 to 2016. Nature Geoscience, 10(9), 668. https://doi.org/10.1038/ngeo2999

Buchanan, M. K., Kopp, R. E., Oppenheimer, M., \& Tebaldi, C. (2016). Allowances for evolving coastal flood risk under uncertain local sea-level rise. Climatic Change, 137(3-4), 347-362. https://doi.org/10.1007/s10584-016-1664-7

Buckley, M. W., Ponte, R. M., Forget, G., \& Heimbach, P. (2015). Determining the origins of advective heat transport convergence variability in the North Atlantic. Journal of Climate, 28(10), 3943-3956. https://doi.org/10.1175/jcli-d-14-00579.1

Burgette, R. J., Weldon, R. J., \& Schmidt, D. A. (2009). Interseismic uplift rates for western Oregon and along-strike variation in locking on the Cascadia subduction zone. Journal of Geophysical Research, 114, B01408. https://doi.org/10.1029/2008jb005679

Calafat, F. M., \& Marcos, M. (2020). Probabilistic reanalysis of storm surge extremes in Europe. Proceedings of the National Academy of Sciences, 201913049. https://doi.org/10.1073/pnas.1913049117

Calafat, F. M., Wahl, T., Lindsten, F., Williams, J., \& Frajka-Williams, E. (2018). Coherent modulation of the sea-level annual cycle in the United States by Atlantic Rossby waves. Nature Communications, 9(1), 2571. https://doi.org/10.1038/s41467-018-06852-4

Caron, L., Ivins, E. R., Larour, E., Adhikari, S., Nilsson, J., \& Blewitt, G. (2018). GIA model statistics for GRACE hydrology, cryosphere, and ocean science. Geophysical Research Letters, 45, 2203-2212. https://doi.org/10.1002/2017gl076644

Carrère, L., \& Lyard, F. (2003). Modeling the barotropic response of the global ocean to atmospheric wind and pressure forcing-comparisons with observations. Geophysical Research Letters, 30(6). 1275. https://doi.org/10.1029/2002gl016473

Carroll, D., Sutherland, D. A., Hudson, B., Moon, T., Catania, G. A., Shroyer, E. L., et al. (2016). The impact of glacier geometry on meltwater plume structure and submarine melt in Greenland fjords. Geophysical Research Letters, 43, 9739-9748. https://doi.org/10.1002/ 2016GL070170

Cazenave, A., Benoit, M., Michael, A., Magdalena, B., Jonathan, B., Valentina, B., et al. (2018). Global sea-level budget 1993-present. Earth System Science Data, 10, 1551-1590. https://doi.org/10.5194/essd-10-1551-2018

Cazenave, A., Dieng, H. B., Meyssignac, B., Von Schuckmann, K., Decharme, B., \& Berthier, E. (2014). The rate of sea-level rise. Nature Climate Change, 4(5), 358. https://doi.org/10.1038/nclimate2159

Cazenave, A., \& Llovel, W. (2010). Contemporary sea-level rise. Annual Review of Marine Science, 2, 145-173. https://doi.org/10.1146/ annurev-marine-120308-081105

Chafik, L., Nilsen, J. E. Ø., Dangendorf, S., Reverdin, G., \& Frederikse, T. (2019). North Atlantic Ocean circulation and decadal sea-level change during the Altimetry era. Scientific Reports, 9(1), 1041. https://doi.org/10.1038/s41598-018-37603-6

Chambers, D. P., Cazenave, A., Champollion, N., Dieng, H., Llovel, W., Forsberg, R., et al. (2017). Evaluation of the global mean sea-level budget between 1993 and 2014. In Integrative Study of the Mean Sea level and Its Components (pp. 315-333). New York, NY: Springer International Publishing. https://doi.org/10.1007/978-3-319-56490-6_14

Chao, B. F., Wu, Y. H., \& Li, Y. S. (2008). Impact of artificial reservoir water impoundment on global sea level. Science, 320(5873), $212-214$. https://doi.org/10.1126/science.1154580

Cheng, L., Trenberth, K. E., Fasullo, J., Boyer, T., Abraham, J., \& Zhu, J. (2017). Improved estimates of ocean heat content from 1960 to 2015. Science Advances, 3(3), e1601545. https://doi.org/10.1126/sciadv.1601545

Church, J. A., Clark, P. U., Cazenave, A., Gregory, J. M., Jevrejeva, S., Levermann, A., et al. (2013). Sea-level change, Cambridge, UK.: PM Cambridge University Press.

Church, J. A., \& White, N. J. (2006). A 20th century acceleration in global sea-level rise. Geophysical Research Letters, 33, L01602. https:// doi.org/10.1029/2005gl024826 
Church, J. A., \& White, N. J. (2011). Sea-level rise from the late 19th to the early 21st century. Surveys in Geophysics, 32(4-5), 585-602. https://doi.org/10.1007/s10712-011-9119-1

Church, J. A., White, N. J., Coleman, R., Lambeck, K., \& Mitrovica, J. X. (2004). Estimates of the regional distribution of sea-level rise over the 1950-2000 period. Journal of Climate, 17(13), 2609-2625. https://doi.org/10.1175/1520-0442(2004)017<2609:eotrdo>2.0.co;2

Dahl, K. A., Fitzpatrick, M. F., \& Spanger-Siegfried, E. (2017). Sea-level rise drives increased tidal flooding frequency at tide gauges along the US East and Gulf Coasts: Projections for 2030 and 2045. PLoS ONE, 12(2), e0170949. https://doi.org/10.1371/journal. pone.0170949

Dangendorf, S., Arns, A., Pinto, J. G., Ludwig, P., \& Jensen, J. (2016). The exceptional influence of storm 'Xaver' on design water levels in the German Bight. Environmental Research Letters, 11(5), 054001. https://doi.org/10.1088/1748-9326/11/5/054001

De Vet, P. L. M., Van Prooijen, B. C., \& Wang, Z. B. (2017). The differences in morphological development between the intertidal flats of the Eastern and Western Scheldt. Geomorphology, 281, 31-42. https://doi.org/10.1016/j.geomorph.2016.12.031

DeConto, R. M., \& Pollard, D. (2016). Contribution of Antarctica to past and future sea-level rise. Nature, 531, 591-597. https://doi.org/ 10.1038 /nature17145

Dehecq, A., Gourmelen, N., Gardner, A. S., Brun, F., Goldberg, D., Nienow, P. W., et al. (2019). Twenty-first century glacier slowdown driven by mass loss in High Mountain Asia. Nature Geoscience, 12(1), 22-27. https://doi.org/10.1038/s41561-018-0271-9

Dehecq, A., Gourmelen, N., \& Trouvé, E. (2015). Deriving large-scale glacier velocities from a complete satellite archive: Application to the Pamir-Karakoram-Himalaya. Remote Sensing of Environment, 162, 55-66. https://doi.org/10.1016/j.rse.2015.01.031

Desbruyères, D. G., Purkey, S. G., McDonagh, E. L., Johnson, G. C., \& King, B. A. (2016). Deep and abyssal ocean warming from 35 years of repeat hydrography. Geophysical Research Letters, 43, 10,356-10,365. https://doi.org/10.1002/2016gl070413

Devlin, A. T., Jay, D. A., Zaron, E. D., Talke, S. A., Pan, J., \& Lin, H. (2017). Tidal variability related to sea-level variability in the Pacific Ocean. Journal of Geophysical Research: Oceans, 122, 8445-8463. https://doi.org/10.1002/2017jc013165

Dieng, H. B., Cazenave, A., Meyssignac, B., \& Ablain, M. (2017). New estimate of the current rate of sea-level rise from a sea-level budget approach. Geophysical Research Letters, 44, 3744-3751. https://doi.org/10.1002/2017gl073308

Dieng, H. B., Cazenave, A., von Schuckmann, K., Ablain, M., \& Meyssignac, B. (2015). Sea-level budget over 2005-2013: Missing contributions and data errors. Ocean Science, 11(5). https://doi.org/10.5194/os-11-789-2015

Dixon, T. H., Amelung, F., Ferretti, A., Novali, F., Rocca, F., Dokka, R., et al. (2006). Space geodesy: Subsidence and flooding in New Orleans. Nature, 441(7093), 587-588. https://doi.org/10.1038/441587a

Doin, M. P., Lasserre, C., Peltzer, G., Cavalié, O., \& Doubre, C. (2009). Corrections of stratified tropospheric delays in SAR interferometry: Validation with global atmospheric models. Journal of Applied Geophysics, 69(1), 35-50. https://doi.org/10.1016/j.jappgeo.2009.03.010

Domingues, C. M., Church, J. A., White, N. J., Gleckler, P. J., Wijffels, S. E., Barker, P. M., \& Dunn, J. R. (2008). Improved estimates of upper-ocean warming and multi-decadal sea-level rise. Nature, 453(7198), 1090. https://doi.org/10.1038/nature07080

Douglas, B., Kearney, M. T., \& Leatherman, S. P. (Eds) (2000). Sea-level rise: History and consequences (Vol. 75). London, UK.: Elsevier.

Durack, P. J., Gleckler, P. J., Landerer, F. W., \& Taylor, K. E. (2014). Quantifying underestimates of long-term upper-ocean warming. Nature Climate Change, 4(11), 999. https://doi.org/10.1038/nclimate2389

Durack, P. J., \& Wijffels, S. E. (2010). Fifty-year trends in global ocean salinities and their relationship to broad-scale warming. Journal of Climate, 23(16), 4342-4362. https://doi.org/10.1175/2010jcli3377.1

Dushaw, B. D., Worcester, P. F., Munk, W. H., Spindel, R. C., Mercer, J. A., Howe, B. M., et al. (2009). A decade of acoustic thermometry in the North Pacific Ocean. Journal of Geophysical Research, 114, C07021. https://doi.org/10.1029/2008JC005124

Edwards, T. L., Brandon, M. A., Durand, G., Edwards, N. R., Golledge, N. R., Holden, P. B., et al. (2019). Revisiting Antarctic ice loss due to marine ice-cliff instability. Nature, 566(7742), 58-64. https://doi.org/10.1038/s41586-019-0901-4

Enderlin, E. M., Howat, I. M., Jeong, S., Noh, M. J., van Angelen, J. H., \& van den Broeke, M. R. (2014). An improved mass budget for the Greenland ice sheet. Geophysical Research Letters, 41, 866-872. https://doi.org/10.1002/2013gl059010

Farinotti, D., Huss, M., Fürst, J. J., Landmann, J., Machguth, H., Maussion, F., \& Pandit, A. (2019). A consensus estimate for the ice thickness distribution of all glaciers on Earth. Nature Geoscience, 12(3), 168. https://doi.org/10.1038/s41561-019-0300-3

Farr, T. G., Rosen, P. A., Caro, E., Crippen, R., Duren, R., Hensley, S., et al. (2007). The Shuttle Radar Topography Mission. Reviews of Geophysics, 45, RG2004. https://doi.org/10.1029/2005RG000183

Farrell, W. E., \& Clark, J. A. (1976). On postglacial sea level. Geophysical Journal International, 46, 647-667. https://doi.org/10.1111/j.1365246x.1976.tb01252.x

Fasullo, J. T., \& Gent, P. R. (2017). On the relationship between regional ocean heat content and sea surface height. Journal of Climate, 30(22), 9195-9211. https://doi.org/10.1175/jcli-d-16-0920.1

Fasullo, J. T., \& Nerem, R. S. (2018). Altimeter-era emergence of the patterns of forced sea-level rise in climate models and implications for the future. Proceedings of the National Academy of Sciences, 115(51), 12944-12949. https://doi.org/10.1073/pnas.1813233115

Ferretti, A., Fumagalli, A., Novali, F., Prati, C., Rocca, F., \& Rucci, A. (2011). A new algorithm for processing interferometric data-stacks: SqueeSAR. IEEE Transactions on Geoscience and Remote Sensing, 49(9), 3460-3470. https://doi.org/10.1109/tgrs.2011.2124465

Fiedler, J. W., \& Conrad, C. P. (2010). Spatial variability of sea level rise due to water impoundment behind dams. Geophysical Research Letters, 37, L12603. https://doi.org/10.1029/2010gl043462

Flanner, M. G., \& Zender, C. S. (2006). Linking snowpack microphysics and albedo evolution. Journal of Geophysical Research, 111 , D12208. https://doi.org/10.1029/2005jd006834

Fokker, P. A., van Leijen, F. J., Orlic, B., van der Marel, H., \& Hanssen, R. F. (2018). Subsidence in the Dutch Wadden Sea. Netherlands Journal of Geosciences, 97(3), 129-181. https://doi.org/10.1017/njg.2018.9

Forget, G., \& Ponte, R. M. (2015). The partition of regional sea-level variability. Progress in Oceanography, 137, 173-195. https://doi.org/ 10.1016/j.pocean.2015.06.002

Frederikse, T., Jevrejeva, S., Riva, R. E., \& Dangendorf, S. (2018). A consistent sea-level reconstruction and its budget on basin and global scales over 1958-2014. Journal of Climate, 31(3), 1267-1280. https://doi.org/10.1175/jcli-d-17-0502.1

Frederikse, T., Landerer, F. W., \& Caron, L. (2019). The imprints of contemporary mass redistribution on local sea level and vertical land motion observations. Solid Earth, 10(6), 1971-1987. https://doi.org/10.5194/se-10-1971-2019

Fretwell, P., Pritchard, H. D., Vaughan, D. G., Bamber, J. L., Barrand, N. E., Bell, R., et al. (2013). Bedmap2: Improved ice bed, surface and thickness datasets for Antarctica. The Cryosphere, 7(1), 375-393. https://doi.org/10.5194/tc-7-375-2013

Fu, L. L., Alsdorf, D., Rodriguez, E., Morrow, R., Mognard, N., Lambin, J., et al. (2009, March). The SWOT (Surface Water and Ocean Topography) mission: Spaceborne radar interferometry for oceanographic and hydrological applications. In OCEANOBS'09 Conference.

Fukumori, I., \& Wang, O. (2013). Origins of heat and freshwater anomalies underlying regional decadal sea-level trends. Geophysical Research Letters, 40, 563-567. https://doi.org/10.1002/grl.50164 
Fyke, J., Sergienko, O., Löfverström, M., Price, S., \& Lenaerts, J. T. (2018). An overview of interactions and feedbacks between ice sheets and the Earth system. Reviews of Geophysics, 56, 361-408. https://doi.org/10.1029/2018rg000600

Gallien, T. W., Sanders, B. F., \& Flick, R. E. (2014). Urban coastal flood prediction: Integrating wave overtopping, flood defenses and drainage. Coastal Engineering, 91, 18-28. https://doi.org/10.1016/j.coastaleng.2014.04.007

Galloway, D. L., \& Burbey, T. J. (2011). Regional land subsidence accompanying groundwater extraction. Hydrogeology Journal, 19(8), 1459-1486. https://doi.org/10.1007/s10040-011-0775-5

Gardner, A., Moholdt, G., Arendt, A., \& Wouters, B. (2012). Accelerated contributions of Canada's Baffin and Bylot Island glaciers to sea-level rise over the past half century. The Cryosphere, 6(5), 1103-1125. https://doi.org/10.5194/tc-6-1103-2012

Gardner, A. S., Moholdt, G., Cogley, J. G., Wouters, B., Arendt, A. A., Wahr, J., et al. (2013). A reconciled estimate of glacier contributions to sea-level rise: 2003 to 2009. Science, 340(6134), 852-857. https://doi.org/10.1126/science.1234532

Gardner, A. S., Moholdt, G., Scambos, T., Fahnstock, M., Ligtenberg, S., van den Broeke, M., \& Nilsson, J. (2018). Increased West Antarctic and unchanged East Antarctic ice discharge over the last 7 years. The Cryosphere, 12(2), 521-547. https://doi.org/10.5194/ tc-12-521-2018

Garner, A. J., Mann, M. E., Emanuel, K. A., Kopp, R. E., Lin, N., Alley, R. B., et al. (2017). Impact of climate change on New York City's coastal flood hazard: Increasing flood heights from the preindustrial to 2300 CE. Proceedings of the National Academy of Sciences, 114(45), 11861-11866. https://doi.org/10.1073/pnas.1703568114

Garner, G. G., \& Keller, K. (2018). Using direct policy search to identify robust strategies in adapting to uncertain sea-level rise and storm surge. Environmental Modelling \& Software, 107, 96-104. https://doi.org/10.1016/j.envsoft.2018.05.006

Garner, A. J., Weiss, J. L., Parris, A., Kopp, R. E., Horton, R. M., Overpeck, J. T., \& Horton, B. P. (2018). Evolution of 21st Century Sea Level Rise Projections. Earth's Future, 6, 1603-1615. https://doi.org/10.1029/2018ef000991

Garry, F. K., McDonagh, E. L., Blaker, A. T., Roberts, C. D., Desbruyères, D. G., Frajka-Williams, E., \& King, B. A. (2019). Model-derived uncertainties in deep ocean temperature trends between 1990 and 2010. Journal of Geophysical Research: Oceans, 124, $1155-1169$. https://doi.org/10.1029/2018jc014225

Gatto, P., \& Carbognin, L. (1981). The Lagoon of Venice: Natural environmental trend and man-induced modification/La Lagune de Venise: l'évolution naturelle et les modifications humaines. Hydrological Sciences Journal, 26(4), 379-391. https://doi.org/10.1080/ 02626668109490902

Glasser, N. F., Scambos, T. A., Bohlander, J., Truffer, M., Pettit, E., \& Davies, B. J. (2011). From ice-shelf tributary to tidewater glacier: Continued rapid recession, acceleration and thinning of Röhss Glacier following the 1995 collapse of the Prince Gustav Ice Shelf, Antarctic Peninsula. Journal of Glaciology, 57(203), 397-406. https://doi.org/10.3189/002214311796905578

Gleckler, P. J., Durack, P. J., Stouffer, R. J., Johnson, G. C., \& Forest, C. E. (2016). Industrial-era global ocean heat uptake doubles in recent decades. Nature Climate Change, 6(4), 394. https://doi.org/10.1038/nclimate2915

Goelzer, H., Nowicki, S., Edwards, T., Beckley, M., Abe-Ouchi, A., Aschwanden, A., et al. (2018). Design and results of the ice sheet model initialisation initMIP-Greenland: An ISMIP6 intercomparison. The Cryosphere, 12(4), 1433-1460. https://doi.org/10.5194/tc-12-14332018

Goelzer, H., Robinson, A., Seroussi, H., \& Van De Wal, R. S. (2017). Recent progress in Greenland ice sheet modelling. Current Climate Change Reports, 3(4), 291-302. https://doi.org/10.1007/s40641-017-0073-y

Goldberg, D. N., \& Heimbach, P. (2013). Parameter and state estimation with a time-dependent adjoint marine ice sheet model. The Cryosphere, 7(6), 1659-1678. https://doi.org/10.5194/tc-7-1659-2013

Goldberg, D. N., Snow, K., Holland, P., Jordan, J. R., Campin, J. M., Heimbach, P., et al. (2018). Representing grounding line migration in synchronous coupling between a marine ice sheet model and a z-coordinate ocean model. Ocean Modelling, 125, 45-60. https://doi.org/ 10.1016/j.ocemod.2018.03.005

Golledge, N. R., Keller, E. D., Gomez, N., Naughten, K. A., Bernales, J., Trusel, L. D., \& Edwards, T. L. (2019). Global environmental consequences of twenty-first-century ice-sheet melt. Nature, 566(7742), 65. https://doi.org/10.1038/s41586-019-0889-9

Gomez, N., Latychev, K., \& Pollard, D. (2018). A coupled ice sheet-sea level model incorporating 3D earth structure: variations in Antarctica during the last deglacial retreat. Journal of Climate, 31, (10), 4041-4054. https://doi.org/10.1175/jcli-d-17-0352.1

Gomez, N., Pollard, D., \& Holland, D. (2015). Sea-level feedback lowers projections of future Antarctic Ice-Sheet mass loss. Nature Communications, 6, 8798. https://doi.org/10.1038/ncomms9798

Gomez, N., Pollard, D., \& Mitrovica, J. X. (2013). A 3-D coupled ice sheet-sea level model applied to Antarctica through the last 40 ky. Earth and Planetary Science Letters, 384, 88-99. https://doi.org/10.1016/j.epsl.2013.09.042

Gomez, N., Pollard, D., Mitrovica, J. X., Huybers, P., \& Clark, P. U. (2012). Evolution of a coupled marine ice sheet-sea level model. Journal of Geophysical Research, 117, F01013. https://doi.org/10.1029/2011jf002128

Greenbaum, J. S., Blankenship, D. D., Young, D. A., Richter, T. G., Roberts, J. L., Aitken, A. R. A., et al. (2015). Ocean access to a cavity beneath Totten Glacier in East Antarctica. Nature Geoscience, 8(4), 294-298. https://doi.org/10.1038/ngeo2388

Gregory, J. M., Griffies, S. M., Hughes, C. W., Lowe, J. A., Church, J. A., Fukimori, I., et al. (2019). Concepts and terminology for sea level: Mean, variability and change, both local and global. Surveys in Geophysics, 1-39. https://doi.org/10.1007/s10712-01909525-z

Gregory, J. M., White, N. J., Church, J. A., Bierkens, M. F. P., Box, J. E., van den Broeke, M. R., et al. (2013). Twentieth-century global-mean sea-level rise: Is the whole greater than the sum of the parts? Journal of Climate, 26(13), 4476-4499. https://doi.org/10.1175/JCLI-D-1200319.1

Haigh, I. D., Pickering, M. D., Green, J. M., Arbic, B. K., Arns, A., Dangendorf, S., et al. (2019). The tides they are a-changin': A comprehensive review of past and future non-astronomical changes in tides, their driving mechanisms and future implications. Reviews of Geophysics, 58. https://doi.org/10.1029/2018rg000636

Hamlington, B. D., Burgos, A., Thompson, P. R., Landerer, F. W., Piecuch, C. G., Adhikari, S., et al. (2018). Observation-driven estimation of the spatial variability of 20th century sea-level rise. Journal of Geophysical Research: Oceans, 123, 2129-2140. https://doi.org/10.1002/ 2017JC013486

Hamlington, B. D., Fasullo, J. T., Nerem, R. S., Kim, K.-Y., \& Landerer, F. W. (2019). Uncovering the pattern of forced sea level rise in the satellite altimeter record. Geophysical Research Letters, 46, 4844-4853. https://doi.org/10.1029/2018gl081386

Hammond, W. C., Blewitt, G., \& Kreemer, C. (2016). GPS imaging of vertical land motion in California and Nevada: Implications for Sierra Nevada uplift. Journal of Geophysical Research: Solid Earth, 121, 7681-7703. https://doi.org/10.1002/2016jb013458

Hammond, W. C., Burgette, R. J., Johnson, K. M., \& Blewitt, G. (2018). Uplift of the western transverse ranges and Ventura area of Southern California: A four-technique geodetic study combining GPS, InSAR, leveling, and tide gauges. Journal of Geophysical Research: Solid Earth, 123, 836-858. https://doi.org/10.1002/2017jb014499 
Han, W., Meehl, G. A., Stammer, D., Hu, A., Hamlington, B., Kenigson, J., et al. (2017). Spatial patterns of sea-level variability associated with natural internal climate modes. In Integrative Study of the Mean Sea level and Its Components (pp. 221-254). New York, NY, USA: Springer.

Hay, C. C., Lau, H. C. P., Gomez, N., Austermann, J., Powell, E., Mitrovica, J. X., et al. (2017). Sea level fingerprints in a region of complex Earth structure: The case of WAIS. Journal of Climate, 30, (6), 1881-1892. https://doi.org/10.1175/JCLI-D-16-0388.1

Hay, C. C., Morrow, E., Kopp, R. E., \& Mitrovica, J. X. (2015). Probabilistic reanalysis of twentieth-century sea-level rise. Nature, 517(7535), 481. https://doi.org/10.1038/nature14093

Hemer, M. A., Wang, X. L., Weisse, R., \& Swail, V. R. (2012). Advancing wind-waves climate science: The COWCLIP project. Bulletin of the American Meteorological Society, 93(6), 791-796. https://doi.org/10.1175/bams-d-11-00184.1

Hirabayashi, Y., Zang, Y., Watanabe, S., Koirala, S., \& Kanae, S. (2013). Projection of glacier mass changes under a high-emission climate scenario using the global glacier model HYOGA2. Hydrological Research Letters, 7(1), 6-11. https://doi.org/10.3178/hrl.7.6

Hock, R., Bliss, A., Marzeion, B., Giesen, R. H., Hirabayashi, Y., Huss, M., et al. (2019). GlacierMIP-A model intercomparison of global-scale glacier mass-balance models and projections. Journal of Glaciology, 65(251), 453-467. https://doi.org/10.1017/jog.2019.22

Holschuh, N., Lilien, D., \& Christianson, K. (2019). Thermal weakening, convergent flow, and vertical heat transport in the Northeast Greenland ice stream shear margins. Geophysical Research Letters, 46, 8184-8193. https://doi.org/10.1029/2019gl083436

Holschuh, N., Parizek, B. R., Alley, R. B., \& Anandakrishnan, S. (2017). Decoding ice sheet behavior using englacial layer slopes. Geophysical Research Letters, 44, 5561-5570. https://doi.org/10.1002/2017gl073417

Holzer, T. L., \& Galloway, D. L. (2005). Impacts of land subsidence caused by withdrawal of underground fluids in the United States. Humans as Geologic Agents, 16, 87. https://doi.org/10.1130/2005.4016(08)

Hooper, A., Bekaert, D., Spaans, K., \& Arıkan, M. (2012). Recent advances in SAR interferometry time series analysis for measuring crustal deformation. Tectonophysics, 514, 1-13. https://doi.org/10.1016/j.tecto.2011.10.013

Horton, B. P., Kopp, R. E., Garner, A. J., Hay, C. C., Khan, N. S., Roy, K., \& Shaw, T. A. (2018). Mapping sea-level change in time, space, and probability. Annual Review of Environment and Resources, 43, 481-521. https://doi.org/10.1146/annurev-environ-102017-025826

Humphrey, V., Gudmundsson, L., \& Seneviratne, S. I. (2017). A global reconstruction of climate-driven subdecadal water storage variability. Geophysical Research Letters, 44, 2300-2309. https://doi.org/10.1002/2017gl072564

Hunter, J. R., Woodworth, P. L., Wahl, T., \& Nicholls, R. J. (2017). Using global tide gauge data to validate and improve the representation of extreme sea levels in flood impact studies. Global and Planetary Change, 156, 34-45. https://doi.org/10.1016/j.gloplacha.2017.06.007

Huss, M. (2013). Density assumptions for converting geodetic glacier volume change to mass change. The Cryosphere, 7(3), 877-887. https://doi.org/10.5194/tc-7-877-2013

Huss, M., Bookhagen, B., Huggel, C., Jacobsen, D., Bradley, R. S., Clague, J. J., et al. (2017). Toward mountains without permanent snow and ice. Earth's Future, 5, 418-435. https://doi.org/10.1002/2016EF000514

Huss, M., \& Hock, R. (2015). A new model for global glacier change and sea-level rise. Frontiers in Earth Science, 3. https://doi.org/10.3389/ feart.2015.00054

Huss, M., \& Hock, R. (2018). Global-scale hydrological response to future glacier mass loss. Nature Climate Change, 8(2), 135. https://doi. org/10.1038/s41558-017-0049-x

Immerzeel, W. W., Van Beek, L. P., \& Bierkens, M. F. (2010). Climate change will affect the Asian water towers. Science, 328(5984), 1382-1385. https://doi.org/10.1126/science.1183188

Irrgang, C., Saynisch, J., \& Thomas, M. (2017). Utilizing oceanic electromagnetic induction to constrain an ocean general circulation model: A data assimilation twin experiment. Journal of Advances in Modeling Earth Systems, 9, 1703-1720. https://doi.org/10.1002/ $2017 \mathrm{~ms} 000951$

Ishii, M., Fukuda, Y., Hirahara, S., Yasui, S., Suzuki, T., \& Sato, K. (2017). Accuracy of global upper ocean heat content estimation expected from present observational data sets. Solaiat, 13, 163-167. https://doi.org/10.2151/sola.2017-030

Ishii, M., \& Kimoto, M. (2009). Reevaluation of historical ocean heat content variations with time-varying XBT and MBT depth bias corrections. Journal of Oceanography, 65(3), 287-299. https://doi.org/10.1007/s10872-009-0027-7

Ivins, E. R., Dokka, R. K., \& Blom, R. G. (2007). Post-glacial sediment load and subsidence in coastal Louisiana. Geophysical Research Letters, 34, L16303. https://doi.org/10.1029/2007GL030003

Jacob, T., Wahr, J., Pfeffer, W. T., \& Swenson, S. (2012). Recent contributions of glaciers and ice caps to sea-level rise. Nature, 482(7386), 514. https://doi.org/10.1038/nature10847

James, T. S., \& Ivins, E. R. (1995). Present-day Antarctic ice mass changes and crustal motion. Geophysical Research Letters, 22(8), 973-976. https://doi.org/10.1029/94gl02800

Jayne, S. R., Wahr, J. M., \& Bryan, F. O. (2003). Observing ocean heat content using satellite gravity and altimetry. Journal of Geophysical Research, 108(C2), 3031. https://doi.org/10.1029/2002jc001619

Jenkins, A., Dutrieux, P., Jacobs, S., Steig, E. J., Gudmundsson, G. H., Smith, J., \& Heywood, K. J. (2016). Decadal ocean forcing and Antarctic ice sheet response: Lessons from the Amundsen Sea. Oceanography, 29(4), 106-117. https://doi.org/10.5670/oceanog.2016.103

Johnson, G. C., Lyman, J. M., \& Purkey, S. G. (2015). Informing deep Argo array design using Argo and full-depth hydrographic section data. Journal of Atmospheric and Oceanic Technology, 32(11), 2187-2198. https://doi.org/10.1175/jtech-d-15-0139.1

Jordà, G., \& Gomis, D. (2013). On the interpretation of the steric and mass components of sea-level variability: The case of the Mediterranean basin. Journal of Geophysical Research: Oceans, 118, 953-963. https://doi.org/10.1002/jgrc.20060

Jordan, T. M., Cooper, M. A., Schroeder, D. M., Williams, C. N., Paden, J. D., Siegert, M. J., \& Bamber, J. L. (2017). Self-affine subglacial roughness: Consequences for radar scattering and basal water discrimination in northern Greenland. The Cryosphere, 11(3), 1247. https://doi.org/10.5194/tc-11-1247-2017

Karegar, M. A., Dixon, T. H., Malservisi, R., Kusche, J., \& Engelhart, S. E. (2017). Nuisance flooding and relative sea-level rise: The importance of present-day land motion. Scientific Reports, 7(1), 11197. https://doi.org/10.1038/s41598-017-11544-y

Karpytchev, M., Ballu, V., Krien, Y., Becker, M., Goodbred, S., Spada, G., et al. (2018). Contributions of a strengthened early Holocene monsoon and sediment loading to present-day subsidence of the Ganges-Brahmaputra Delta. Geophysical Research Letters, 45 , 1433-1442. https://doi.org/10.1002/2017GL076388

Kaser, G., Cogley, J. G., Dyurgerov, M. B., Meier, M. F., \& Ohmura, A. (2006). Mass balance of glaciers and ice caps: Consensus estimates for 1961-2004. Geophysical Research Letters, 33, L19501. https://doi.org/10.1029/2006gl027511

Kaser, G., Großhauser, M., \& Marzeion, B. (2010). Contribution potential of glaciers to water availability in different climate regimes. Proceedings of the National Academy of Sciences, 107, (47), 20223-20227. https://doi.org/10.1073/pnas.1008162107

Kjeldsen, K. K., Korsgaard N. J., Bjørk A. A., Khan S. A., Box J. E., Funder S., et al. (2015). Spatial and temporal distribution of mass loss from the Greenland Ice Sheet since AD 1900. Nature, 528, (7582), 396-400. https://doi.org/10.1038/nature16183 
Khazendar, A., Borstad, C. P., Scheuchl, B., Rignot, E., \& Seroussi, H. (2015). The evolving instability of the remnant Larsen B ice shelf and its tributary glaciers. Earth and Planetary Science Letters, 419, 199-210. https://doi.org/10.1016/j.epsl.2015.03.014

Khazendar, A., Rignot, E., Schroeder, D. M., Seroussi, H., Schodlok, M. P., Scheuchl, B., et al. (2016). Rapid submarine ice melting in the grounding zones of ice shelves in West Antarctica. Nature Communications, 7(1), 13243. https://doi.org/10.1038/ncomms13243

Kim, J. S., Seo, K. W., Jeon, T., Chen, J., \& Wilson, C. R. (2019). Missing hydrological contribution to sea level rise. Geophysical Research Letters, 46, 12,049-12,055. https://doi.org/10.1029/2019g1085470

King, M. A., Keshin, M., Whitehouse, P. L., Thomas, I. D., Milne, G., \& Riva, R. E. (2012). Regional biases in absolute sea-level estimates from tide gauge data due to residual unmodeled vertical land movement. Geophysical Research Letters, 39, L14604. https://doi.org/ $10.1029 / 2012$ gl052348

Kleinherenbrink, M., Riva, R., \& Frederikse, T. (2018). A comparison of methods to estimate vertical land motion trends from GNSS and altimetry at tide gauge stations. Ocean Science, 14(2). https://doi.org/10.5194/os-14-187-2018

Köhl, A., Sena Martins, M., \& Stammer, D. (2014). Impact of assimilating surface salinity from SMOS on ocean circulation estimates. Journal of Geophysical Research: Oceans, 119, 5449-5464. https://doi.org/10.1002/2014jc010040

Konrad, H., Sasgen, I., Pollard, D., \& Klemann, V. (2015). Potential of the solid-Earth response for limiting long-term West Antarctic Ice Sheet retreat in a warming climate. Earth and Planetary Science Letters, 432, 254-264. https://doi.org/10.1016/j.epsl.2015.10.008

Kooi, H., \& De Vries, J. J. (1998). Land subsidence and hydrodynamic compaction of sedimentary basins. Hydrology and Earth System Sciences, 2(2/3), 159-171. https://doi.org/10.5194/hess-2-159-1998

Kopp, R. E., DeConto, R. M., Bader, D. A., Hay, C. C., Horton, R. M., Kulp, S., et al. (2017). Evolving understanding of Antarctic ice-sheet physics and ambiguity in probabilistic sea-level projections. Earth's Future, 5, 1217-1233. https://doi.org/10.1002/2017EF000663

Kopp, R. E., Hay, C. C., Little, C. M., \& Mitrovica, J. X. (2015). Geographic variability of sea-level change. Current Climate Change Reports, 1(3), 192-204. https://doi.org/10.1007/s40641-015-0015-5

Kopp, R. E., Horton, R. M., Little, C. M., Mitrovica, J. X., Oppenheimer, M., Rasmussen, D. J., et al. (2014). Probabilistic 21st and 22nd century sea-level projections at a global network of tide-gauge sites. Earth's Future, 2, 383-406. https://doi.org/10.1002/2014EF000239

Kopp, R. E., Kemp, A. C., Bittermann, K., Horton, B. P., Donnelly, J. P., Gehrels, W. R., et al. (2016). Temperature-driven global sea-level variability in the Common Era. Proceedings of the National Academy of Sciences, 113, (11), E1434-E1441. https://doi.org/10.1073/ pnas. 1517056113

Kraaijenbrink, P. D. A., Bierkens, M. F. P., Lutz, A. F., \& Immerzeel, W. W. (2017). Impact of a global temperature rise of 1.5 degrees Celsius on Asia's glaciers. Nature, 549(7671), -257. https://doi.org/10.1038/nature23878

Kuchar, J., Milne, G., Wolstencroft, M., Love, R., Tarasov, L., \& Hijma, M. (2017). The influence of sediment isostatic adjustment on sea level change and land motion along the U.S. Gulf Coast. Journal of Geophysical Research: Solid Earth, 123, 780-796. https://doi.org/ 10.1002/2017JB014695

Larour, E., Ivins, E. R., \& Adhikari, S. (2017). Should coastal planners have concern over where land ice is melting? Science Advances, 3(11), e1700537. https://doi.org/10.1126/sciadv.1700537

Larour, E., Seroussi, H., Adhikari, S., Ivins, E., Caron, L., Morlighem, M., \& Schlegel, N. (2019). Slowdown in Antarctic mass loss from solid Earth and sea-level feedbacks. Science, 364, (6444), eaav7908. https://doi.org/10.1126/science.aav7908

Larour, E., Seroussi, H., Morlighem, M., \& Rignot, E. (2012). Continental scale, high order, high spatial resolution, ice sheet modeling using the Ice Sheet System Model (ISSM). Journal of Geophysical Research, 117, F01022. https://doi.org/10.1029/2011jf002140

Larour, E., Utke, J., Csatho, B., Schenk, A., Seroussi, H., Morlighem, M., et al. (2014). Inferred basal friction and surface mass balance of the Northeast Greenland Ice Stream using data assimilation of ICESat (Ice Cloud and land Elevation Satellite) surface altimetry and ISSM (Ice Sheet System Model). The Cryosphere, 8(6), 2335-2351. https://doi.org/10.5194/tc-8-2335-2014

Larsen, C. F., Burgess, E., Arendt, A. A., O'neel, S., Johnson, A. J., \& Kienholz, C. (2015). Surface melt dominates Alaska glacier mass balance. Geophysical Research Letters, 42, 5902-5908. https://doi.org/10.1002/2015gl064349

Larsen, C. F., Motyka, R. J., Freymueller, J. T., Echelmeyer, K. A., \& Ivins, E. R. (2005). Rapid viscoelastic uplift in southeast Alaska caused by post-Little Ice Age glacial retreat. Earth and Planetary Science Letters, 237(3-4), 548-560. https://doi.org/10.1016/j. epsl.2005.06.032

Latychev, K., Mitrovica, J. X., Tromp, J., Tamisiea, M. E., Komatitsch, D., \& Christara, C. C. (2005). Glacial isostatic adjustment on 3-D Earth models: A finite-volume formulation. Geophysical Journal International, 161, (2), 421-444. https://doi.org/10.1111/j.1365246x.2005.02536.x

Le Reste, S., Dutreuil, V., André, X., Thierry, V., Renaut, C., Le Traon, P. Y., \& Maze, G. (2016). “Deep-Arvor”: A new profiling float to extend the argo observations down to 4000-m depth. Journal of Atmospheric and Oceanic Technology, 33(5), 1039-1055. https://doi.org/ $10.1175 /$ jtech-d-15-0214.1

Lenaerts, J. T., Medley, B., van den Broeke, M. R., \& Wouters, B. (2019). Observing and modeling ice-sheet surface mass balance. Reviews of Geophysics, 57, 376-420. https://doi.org/10.1029/2018rg000622

Lenaerts, J. T. M., Lhermitte, S., Drews, R., Ligtenberg, S. R. M., Berger, S., Helm, V., et al. (2017). Meltwater produced by wind-albedo interaction stored in an East Antarctic ice shelf. Nature Climate Change, 7(1), 58-62. https://doi.org/10.1038/nclimate3180

Lettenmaier, D. P., \& Milly, P. C. D. (2009). Land waters and sea level. Nature Geoscience, 2(7), 452. https://doi.org/10.1038/ngeo567

Levitus, S., Antonov, J. I., Boyer, T. P., Baranova, O. K., Garcia, H. E., Locarnini, R. A., et al. (2012). World ocean heat content and thermosteric sea-level change (0-2000 m), 1955-2010. Geophysical Research Letters, 39, L10603. https://doi.org/10.1029/2012gl051106

Lipscomb, W. H., Fyke, J. G., Vizcaíno, M., Sacks, W. J., Wolfe, J., Vertenstein, M., et al. (2013). Implementation and initial evaluation of the glimmer community ice sheet model in the community earth system model. Journal of Climate, 26(19), 7352-7371. https://doi.org/ 10.1175/JCLI-D-12-00557.1

Little, C. M., Urban, N. M., \& Oppenheimer, M. (2013). Probabilistic framework for assessing the ice sheet contribution to sea-level change. Proceedings of the National Academy of Sciences, 110(9), 3264-3269. https://doi.org/10.1073/pnas.1214457110

Liu, Y., Moore, J. C., Cheng, X., Gladstone, R. M., Bassis, J. N., Liu, H., et al. (2015). Ocean-driven thinning enhances iceberg calving and retreat of Antarctic ice shelves. Proceedings of the National Academy of Sciences, 112(11), 3263-3268. https://doi.org/10.1073/ pnas. 1415137112

Llovel, W., Becker, M., Cazenave, A., Jevrejeva, S., Alkama, R., Decharme, B., et al. (2011). Terrestrial waters and sea-level variations on interannual time scale. Global and Planetary Change, 75(1-2), 76-82. https://doi.org/10.1016/j.gloplacha.2010.10.008

Llovel, W., \& Lee, T. (2015). Importance and origin of halosteric contribution to sea-level change in the southeast Indian Ocean during 2005-2013. Geophysical Research Letters, 42, 1148-1157. https://doi.org/10.1002/2014gl062611

Llovel, W., \& Terray, L. (2016). Observed southern upper-ocean warming over 2005-2014 and associated mechanisms. Environmental Research Letters, 11(12), 124023. https://doi.org/10.1088/1748-9326/11/12/124023 
Llovel, W., Willis, J. K., Landerer, F. W., \& Fukumori, I. (2014). Deep-ocean contribution to sea level and energy budget not detectable over the past decade. Nature Climate Change, 4(11), 1031. https://doi.org/10.1038/nclimate2387

Lobeto, H., Menendez, M., \& Losada, I. J. (2018). Toward a methodology for estimating coastal extreme sea levels from satellite altimetry. Journal of Geophysical Research: Oceans, 123, 8284-8298. https://doi.org/10.1029/2018jc014487

Lorbacher, K., Marsland, S. J., Church, J. A., Griffies, S. M., \& Stammer, D. (2012). Rapid barotropic sea level rise from ice sheet melting. Journal of Geophysical Research, 117, C06003. https://doi.org/10.1029/2011jc007733

Lowe, J. A., \& Gregory, J. M. (2006). Understanding projections of sea-level rise in a Hadley Centre coupled climate model. Journal of Geophysical Research, 111, C11014. https://doi.org/10.1029/2005jc003421

Lowe, J. A., Woodworth, P. L., Knutson, T., McDonald, R. E., McInnes, K. L., Woth, K., et al. (2010). Past and future changes in extreme sea levels and waves. In Understanding sea-level rise and variability (pp. 326-375). Oxford, UK: Blackwell Publishing Ltd. https://doi.org/ 10.1002/9781444323276.ch11

Lyman, J. M., \& Johnson, G. C. (2014). Estimating global ocean heat content changes in the upper 1800 m since 1950 and the influence of climatology choice. Journal of Climate, 27(5), 1945-1957. https://doi.org/10.1175/jcli-d-12-00752.1

MacGregor, J. A., Li, J., Paden, J. D., Catania, G. A., Clow, G. D., Fahnestock, M. A., et al. (2015). Radar attenuation and temperature within the Greenland Ice Sheet. Journal of Geophysical Research: Earth Surface, 120, 983-1008. https://doi.org/10.1002/2014JF003418

Marzeion, B., Champollion, N., Haeberli, W., Langley, K., Leclercq, P., \& Paul, F. (2017). Observation-based estimates of global glacier mass change and its contribution to sea-level change. In Integrative study of the mean sea level and its components (pp. 107-132). New York, NY: Springer. https://doi.org/10.1007/978-3-319-56490-6_6

Marzeion, B., Cogley, J. G., Richter, K., \& Parkes, D. (2014). Attribution of global glacier mass loss to anthropogenic and natural causes. Science, 345(6199), 919-921. https://doi.org/10.1126/science.1254702

Marzeion, B., Jarosch, A. H., \& Hofer, M. (2012). Past and future sea-level change from the surface mass balance of glaciers. The Cryosphere, 6(6), 1295-1322. https://doi.org/10.5194/tc-6-1295-2012

Mawdsley, R. J., \& Haigh, I. D. (2016). Spatial and temporal variability and long-term trends in skew surges globally. Frontiers in Marine Science, 3, 29. https://doi.org/10.3389/fmars.2016.00029

Mawdsley, R. J., Haigh, I. D., \& Wells, N. C. (2015). Global secular changes in different tidal high water, low water and range levels. Earth's Future, 3, 66-81. https://doi.org/10.1002/2014ef000282

Mazzotti, S., Lambert, A., Van der Kooij, M., \& Mainville, A. (2009). Impact of anthropogenic subsidence on relative sea-level rise in the Fraser River delta. Geology, 37(9), 771-774. https://doi.org/10.1130/g25640a.1

Mazzotti, S., Leonard, L. J., Hyndman, R. D., \& Cassidy, J. F. (2008). Tectonics, dynamics, and seismic hazard in the Canada-Alaska Cordillera. Active Tectonics and Seismic Potential of Alaska, 179, 297-319. https://doi.org/10.1029/179gm17

Meckel, T. A., ten Brink, U. S., \& Williams, S. J. (2006). Current subsidence rates due to compaction of Holocene sediments in southern Louisiana. Geophysical Research Letters, 33, L11403. https://doi.org/10.1029/2006gl026300

Melet, A., Meyssignac, B., Almar, R., \& Le Cozannet, G. (2018). Under-estimated wave contribution to coastal sea-level rise. Nature Climate Change, 8(3), 234. https://doi.org/10.1038/s41558-018-0088-y

Menéndez, M., \& Woodworth, P. L. (2010). Changes in extreme high water levels based on a quasi-global tide-gauge data set. Journal of Geophysical Research, 115, C10011. https://doi.org/10.1029/2009jc005997

Merrifield, M. A., Genz, A. S., Kontoes, C. P., \& Marra, J. J. (2013). Annual maximum water levels from tide gauges: Contributing factors and geographic patterns. Journal of Geophysical Research: Oceans, 118, 2535-2546. https://doi.org/10.1002/jgrc.20173

Merrifield, M. A., \& Maltrud, M. E. (2011). Regional sea-level trends due to a Pacific trade wind intensification. Geophysical Research Letters, 38, L21605. https://doi.org/10.1029/2011gl049576

Mey, J., Scherler, D., Wickert, A. D., Egholm, D. L., Tesauro, M., Schildgen, T. F., \& Strecker, M. R. (2016). Glacial isostatic uplift of the European Alps. Nature Communications, 7(13382). https://doi.org/10.1038/ncomms13382

Miller, M. M., \& Shirzaei, M. (2019). Land subsidence in Houston correlated with flooding from Hurricane Harvey. Remote Sensing of Environment, 225, 368-378. https://doi.org/10.1016/j.rse.2019.03.022

Miller, M. M., Shirzaei, M., \& Argus, D. (2017). Aquifer mechanical properties and decelerated compaction in Tucson, Arizona. Journal of Geophysical Research: Solid Earth, 122, 8402-8416. https://doi.org/10.1002/2017jb014531

Milly, P. C. D., Cazenave, A., \& Gennero, C. (2003). Contribution of climate-driven change in continental water storage to recent sea-level rise. Proceedings of the National Academy of Sciences, 100(23), 13158-13161. https://doi.org/10.1073/pnas.2134014100

Milne, G. A., Gehrels, W. R., Hughes, C. W., \& Tamisiea, M. E. (2009). Identifying the causes of sea-level change. Nature Geoscience, 2(7), 471. https://doi.org/10.1038/ngeo544

Milne, G. A., \& Mitrovica, J. X. (1998). Postglacial sea-level change on a rotating Earth. Geophysical Journal International, 133(1), 1-19. https://doi.org/10.1046/j.1365-246x.1998.1331455.x

Milne, G. A., \& Mitrovica, J. X. (2008). Searching for eustasy in deglacial sea-level histories. Quaternary Science Reviews, 27, (25-26), 2292-2302. https://doi.org/10.1016/j.quascirev.2008.08.018

Minobe, S., Terada, M., Qiu, B., \& Schneider, N. (2017). Western boundary sea level: A theory, rule of thumb, and application to climate models. Journal of Physical Oceanography, 47(5), 957-977. https://doi.org/10.1175/jpo-d-16-0144.1

Mitrovica, J. X., Hay, C. C., Kopp, R. E., Harig, C., \& Latychev, K. (2018). Quantifying the sensitivity of sea-level change in coastal localities to the geometry of polar ice mass flux. Journal of Climate, 31(9), 3701-3709. https://doi.org/10.1175/jcli-d-17-0465.1

Mitrovica, J. X., \& Milne, G. A. (2002). On the origin of late Holocene sea-level highstands within equatorial ocean basins. Quaternary Science Reviews, 21, (20-22), 2179-2190. https://doi.org/10.1016/S0277-3791(02)00080-X

Mitrovica, J. X., \& Milne, G. A. (2003). On post-glacial sea level: I. General theory. Geophysical Journal International, 154, (2), $253-267$. https://doi.org/10.1046/j.1365-246X.2003.01942.X

Mitrovica, J. X., \& Peltier, W. R. (1993). The inference of mantle viscosity from an inversion of the Fennoscandian relaxation spectrum. Geophysical Journal International, 114, (1), 45-62. https://doi.org/10.1111/j.1365-246x.1993.tb01465.x

Mitrovica, J. X., Tamisiea, M. E., Davis, J. L., \& Milne, G. A. (2001). Recent mass balance of polar ice sheets inferred from patterns of global sea-level change. Nature, 409(6823), 1026. https://doi.org/10.1038/35059054

Moftakhari, H. R., AghaKouchak, A., Sanders, B. F., Allaire, M., \& Matthew, R. A. (2018). What is nuisance flooding? Defining and monitoring an emerging challenge. Water Resources Research, 54, 4218-4227. https://doi.org/10.1029/2018wr022828

Moftakhari, H. R., Salvadori, G., AghaKouchak, A., Sanders, B. F., \& Matthew, R. A. (2017). Compounding effects of sea level rise and fluvial flooding. Proceedings of the National Academy of Sciences, 114, (37), 9785-9790. https://doi.org/10.1073/pnas.1620325114

Moholdt, G., Wouters, B., \& Gardner, A. S. (2012). Recent mass changes of glaciers in the Russian High Arctic. Geophysical Research Letters, 39, L10502. https://doi.org/10.1029/2012gl051466 
Morlighem, M., Bondzio, J., Seroussi, H., Rignot, E., Larour, E., Humbert, A., \& Rebuffi, S. (2016). Modeling of Store Gletscher's calving dynamics, West Greenland, in response to ocean thermal forcing. Geophysical Research Letters, 43, 2659-2666. https://doi.org/10.1002/ $2016 \mathrm{gl067695}$

Morlighem, M., Rignot, E., Mouginot, J., Seroussi, H., \& Larour, E. (2014). Deeply incised submarine glacial valleys beneath the Greenland ice sheet. Nature Geoscience, 7(6), 418. https://doi.org/10.1038/ngeo2167

Morlighem, M., Rignot, E., Seroussi, H., Larour, E., Ben Dhia, H., \& Aubry, D. (2010). Spatial patterns of basal drag inferred using control methods from a full-Stokes and simpler models for Pine Island Glacier, West Antarctica. Geophysical Research Letters, 37, L14502. https://doi.org/10.1029/2010gl043853

Morlighem, M., Williams, C. N., Rignot, E., An, L., Arndt, J. E., Bamber, J. L., et al. (2017). BedMachine v3: Complete bed topography and ocean bathymetry mapping of Greenland from multibeam echo sounding combined with mass conservation. Geophysical Research Letters, 44, 11,051-11,061. https://doi.org/10.1002/2017gl074954

Motyka, R. J., Hunter, L., Echelmeyer, K. A., \& Connor, C. (2003). Submarine melting at the terminus of a temperate tidewater glacier, LeConte Glacier, Alaska, USA. Annals of Glaciology, 36, 57-65. https://doi.org/10.3189/172756403781816374

Mouginot, J., Rignot, E., Bjørk, A. A., van den Broeke, M., Millan, R., Morlighem, M., et al. (2019). Forty-six years of Greenland Ice Sheet mass balance from 1972 to 2018. Proceedings of the National Academy of Sciences, 116(19), 9239-9244. https://doi.org/10.1073/ pnas. 1904242116

Mouginot, J., Rignot, E., \& Scheuchl, B. (2014). Sustained increase in ice discharge from the Amundsen Sea Embayment, West Antarctica, from 1973 to 2013. Geophysical Research Letters, 41, 1576-1584. https://doi.org/10.1002/2013gl059069

Muis, S., Haigh, I. D., Guimarães Nobre, G., Aerts, J. C., \& Ward, P. J. (2018). Influence of El Niño-Southern Oscillation on global coastal flooding. Earth's Future, 6, 1311-1322. https://doi.org/10.1029/2018ef000909

Muis, S., Verlaan, M., Winsemius, H. C., Aerts, J. C., \& Ward, P. J. (2016). A global reanalysis of storm surges and extreme sea levels. Nature Communications, 7, 11969. https://doi.org/10.1038/ncomms12913

Munk, W. (2003). Ocean freshening, sea-level rising. Science, 300(5628), 2041-2043. https://doi.org/10.1126/science.1085534

Munk, W., \& Wunsch, C. (1979). Ocean acoustic tomography: A scheme for large scale monitoring. Deep sea research part A. Oceanographic Research Papers, 26(2), 123-161. https://doi.org/10.1016/0198-0149(79)90073-6

Nerem, R. S., Beckley, B. D., Fasullo, J. T., Hamlington, B. D., Masters, D., \& Mitchum, G. T. (2018). Climate-change-driven accelerated sea-level rise detected in the altimeter era. Proceedings of the National Academy of Sciences, 115(9), 2022-2025. https://doi.org/10.1073/ pnas. 1717312115

Nerem, R. S., \& Mitchum, G. T. (2002). Estimates of vertical crustal motion derived from differences of TOPEX/POSEIDON and tide gauge sea-level measurements. Geophysical Research Letters, 29(19) 1934. https://doi.org/10.1029/2002gl015037

Neumann, T. A., Martino, A. J., Markus, T., Bae, S., Bock, M. R., Brenner, A. C., et al. (2019). The ice, cloud, and land elevation satellite-2 Mission: A global geolocated photon product. Remote Sensing of Environment, 233, 1-17. https://doi.org/10.1016/j.rse.2019.111325

Nias, I. J., Cornford, S. L., \& Payne, A. J. (2018). New mass-conserving bedrock topography for Pine Island Glacier impacts simulated decadal rates of mass loss. Geophysical Research Letters, 45, 3173-3181. https://doi.org/10.1002/2017gl076493

Nias, I. J., Cornford, S. L., \& Payne, A. J. (2016). Contrasting the modelled sensitivity of the Amundsen Sea Embayment ice streams. Journal of Glaciology, 62(233), 552-562. https://doi.org/10.1017/jog.2016.40

Nicholls, R. J. (2011). Planning for the impacts of sea-level rise. Oceanography, 24(2), 144-157. https://doi.org/10.5670/oceanog.2011.34

Nicholls, R. J., \& Cazenave, A. (2010). Sea-level rise and its impact on coastal zones. Science, 328(5985), 1517-1520. https://doi.org/10.1126/ science.1185782

Nield, G. A., Barletta, V. R., Bordoni, A., King, M. A., Whitehouse, P. L., Clarke, P. J., et al. (2014). Rapid bedrock uplift in the Antarctic Peninsula explained by viscoelastic response to recent ice unloading. Earth and Planetary Science Letters, 397, 32-41. https://doi.org/ 10.1016/j.epsl.2014.04.019

Noël, B., van de Berg, W. J., Wessem, V., Melchior, J., Van Meijgaard, E., Van As, D., et al. (2018). Modelling the climate and surface mass balance of polar ice sheets using RACMO2-Part 1: Greenland (1958-2016). The Cryosphere, 12(3), 811-831.https://doi.org/10.5194/tc-12811-2018

Nowicki, S., \& Seroussi, H. (2018). Projections of future sea-level contributions from the Greenland and Antarctic Ice Sheets: Challenges beyond dynamical ice sheet modeling. Oceanography, 31(2), 109-117. https://doi.org/10.5670/oceanog.2018.216

Nowicki, S. M., Payne, T., Larour, E., Seroussi, H., Goelzer, H., Lipscomb, W., et al. (2016). Ice sheet model intercomparison project (ISMIP6) contribution to CMIP6. Geoscientific Model Development, 9(12), 4521. https://doi.org/10.5194/gmd-9-4521-2016

Ojha, C., Shirzaei, M., Werth, S., Argus, D. F., \& Farr, T. G. (2018). Sustained groundwater loss in California's Central Valley exacerbated by intense drought periods. Water Resources Research, 54, 4449-4460. https://doi.org/10.1029/2017wr022250

Ojha, C., Werth, S., \& Shirzaei, M. (2019). Groundwater loss and aquifer system compaction in San Joaquin Valley during 2012-2015 drought. Journal of Geophysical Research: Solid Earth, 124, 3127-3143. https://doi.org/10.1029/2018jb016083

Oppenheimer, M., \& Alley, R. B. (2016). How high will the seas rise? Science, 354(6318), 1375-1377. https://doi.org/10.1126/science. aak9460

Östrem, G. (1959). Ice melting under a thin layer of moraine, and the existence of ice cores in moraine ridges. Geografiska Annaler, 41(4), 228-230. https://doi.org/10.1080/20014422.1959.11907953

Padman, L., Siegfried, M. R., \& Fricker, H. A. (2018). Ocean tide influences on the Antarctic and Greenland Ice Sheets. Reviews of Geophysics, 56, 142-184. https://doi.org/10.1002/2016rg000546

Painter, T. H., Rittger, K., McKenzie, C., Slaughter, P., Davis, R. E., \& Dozier, J. (2009). Retrieval of subpixel snow covered area, grain size, and albedo from MODIS. Remote Sensing of Environment, 113(4), 868-879. https://doi.org/10.1016/j.rse.2009.01.001

Palter, J. B., Caron, C. A., Law, K. L., Willis, J. K., Trossman, D. S., Yashayaev, I. M., \& Gilbert, D. (2016). Variability of the directly observed, middepth subpolar North Atlantic circulation. Geophysical Research Letters, 43, 2700-2708. https://doi.org/10.1002/2015gl067235

Paolo, F. S., Fricker, H. A., \& Padman, L. (2015). Volume loss from Antarctic ice shelves is accelerating. Science, 348(6232), 327-331. https:// doi.org/10.1126/science.aaa0940

Parizek, B. R., Christianson, K., Alley, R. B., Voyotenko, D., Vaňková, I., Dixon, T. H., \& Holland, D. M. (2019). Ice-cliff failure via retrogressive slumping. Geology, 47, 1-4. https://doi.org/10.1130/G45880.1

Parizek, B. R., Christianson, K., Anandakrishnan, S., Alley, R. B., Walker, R. T., Edwards, R. A., et al. (2013). Dynamic (in) stability of Thwaites Glacier, West Antarctica. Journal of Geophysical Research: Earth Surface, 118, 638-655. https://doi.org/10.1002/ jgrf.20044

Pattyn, F. (2017). Sea-level response to melting of Antarctic ice shelves on multi-centennial timescales with the fast Elementary Thermomechanical Ice Sheet model (f. ETISh v1. 0). The Cryosphere, 11(4), 1851-1878. https://doi.org/10.5194/tc-11-1851-2017 
Pattyn, F., Perichon, L., Durand, G., Favier, L., Gagliardini, O., Hindmarsh, R. C., et al. (2013). Grounding-line migration in plan-view marine ice-sheet models: Results of the ice2sea MISMIP3d intercomparison. Journal of Glaciology, 59(215), 410-422. https://doi.org/ 10.3189/2013jog12j129

Pattyn, F., Schoof, C., Perichon, L., Hindmarsh, R. C. A., Bueler, E., De Fleurian, B., et al. (2012). Results of the marine ice sheet model intercomparison project, MISMIP. The Cryosphere, 6(3), 573-588. https://doi.org/10.5194/tc-6-573-2012

Perrette, M., Landerer, F., Riva, R., Frieler, K., \& Meinshausen, M. (2013). A scaling approach to project regional sea-level rise and its uncertainties. Earth System Dynamics, 4(1), 11-29. https://doi.org/10.5194/esd-4-11-2013

Peyser, C. E., Yin, J., Landerer, F. W., \& Cole, J. E. (2016). Pacific sea-level rise patterns and global surface temperature variability. Geophysical Research Letters, 43, 8662-8669. https://doi.org/10.1002/2016gl069401

Pfeffer, W. T., Arendt, A. A., Bliss, A., Bolch, T., Cogley, J. G., Gardner, A. S., et al. (2014). The Randolph glacier inventory: A globally complete inventory of glaciers. Journal of Glaciology, 60(221), 537-552. https://doi.org/10.3189/2014jog13j176

Pickering, A., \& Alford, M. H. (2012). Velocity structure of internal tide beams emanating from Kaena Ridge, Hawaii. Journal of Physical Oceanography, 42(6), 1039-1044. https://doi.org/10.1175/jpo-d-12-018.1

Piecuch, C. G., Bittermann, K., Kemp, A. C., Ponte, R. M., Little, C. M., Engelhart, S. E., \& Lentz, S. J. (2018). River-discharge effects on United States Atlantic and Gulf coast sea-level changes. Proceedings of the National Academy of Sciences, 115(30), 7729-7734. https://doi. org/10.1073/pnas.1805428115

Piecuch, C. G., \& Ponte, R. M. (2011). Mechanisms of interannual steric sea-level variability. Geophysical Research Letters, 38, L15605. https://doi.org/10.1029/2011gl048440

Piecuch, C. G., Ponte, R. M., Little, C. M., Buckley, M. W., \& Fukumori, I. (2017). Mechanisms underlying recent decadal changes in subpolar North Atlantic Ocean heat content. Journal of Geophysical Research: Oceans, 122, 7181-7197. https://doi.org/10.1002/ $2017 \mathrm{jc} 012845$

Pieczonka, T., \& Bolch, T. (2015). Region-wide glacier mass budgets and area changes for the Central Tien Shan between 1975 and 1999 using Hexagon KH-9 imagery. Global and Planetary Change, 128, 1-13. https://doi.org/10.1016/j.gloplacha.2014.11.014

Porter, D. F., Tinto, K. J., Boghosian, A. L., Csatho, B. M., Bell, R. E., \& Cochran, J. R. (2018). Identifying spatial variability in Greenland's outlet glacier response to ocean heat. Frontiers in Earth Science, 6, 90. https://doi.org/10.3389/feart.2018.00090

Pritchard, H. D., Arthern, R. J., Vaughan, D. G., \& Edwards, L. A. (2009). Extensive dynamic thinning on the margins of the Greenland and Antarctic ice sheets. Nature, 461(7266), 971. https://doi.org/10.1038/nature08471

Pugh, D., \& Woodworth, P. (2014). Sea-level science: Understanding tides, surges, tsunamis and mean sea-level changes. Cambridge, UK: Cambridge University Press.

Purcell, A., Dehecq, A., Tregoning, P., Potter, E.-K., McClusky, S. C., \& Lambeck, K. (2011). Relationship between glacial isostatic adjustment and gravity perturbations observed by GRACE. Geophysical Research Letters, 38, L18305. https://doi.org/10.1029/ $2011 \mathrm{gl} 048624$

Purkey, S. G., \& Johnson, G. C. (2010). Warming of global abyssal and deep Southern Ocean waters between the 1990s and 2000s: Contributions to global heat and sea-level rise budgets. Journal of Climate, 23(23), 6336-6351. https://doi.org/10.1175/ 2010jcli3682.1

Radić, V., Bliss, A., Beedlow, A. C., Hock, R., Miles, E., \& Cogley, J. G. (2014). Regional and global projections of twenty-first century glacier mass changes in response to climate scenarios from global climate models. Climate Dynamics, 42(1-2), 37-58. https://doi.org/10.1007/ s00382-013-1719-7

Radić, V., \& Hock, R. (2011). Regionally differentiated contribution of mountain glaciers and ice caps to future sea-level rise. Nature Geoscience, 4(2), 91. https://doi.org/10.1038/ngeo1052

Radić, V., \& Hock, R. (2014). Glaciers in the Earth's hydrological cycle: Assessments of glacier mass and runoff changes on global and regional scales. Surveys in Geophysics, 35(3), 813-837. https://doi.org/10.1007/s10712-013-9262-y

Rasmussen, D. J., Bittermann, K., Buchanan, M. K., Kulp, S., Strauss, B. H., Kopp, R. E., \& Oppenheimer, M. (2018). Extreme sea-level implications of $1.5^{\circ} \mathrm{C}, 2.0^{\circ} \mathrm{C}$, and $2.5^{\circ} \mathrm{C}$ temperature stabilization targets in the 21st and 22nd centuries. Environmental Research Letters, 13(3), 034040. https://doi.org/10.1088/1748-9326/aaac87

Ray, R. D., \& Beckley, B. D. (2012). Calibration of ocean wave measurements by the TOPEX, Jason-1, and Jason-2 satellites. Marine Geodesy, 35(sup1), 238-257. https://doi.org/10.1080/01490419.2012.718611

Ray, R. D., \& Foster, G. (2016). Future nuisance flooding at Boston caused by astronomical tides alone. Earth's Future, 4, 578-587. https:// doi.org/10.1002/2016ef000423

Reager, J. T., Gardner, A. S., Famiglietti, J. S., Wiese, D. N., Eicker, A., \& Lo, M. H. (2016). A decade of sea-level rise slowed by climate-driven hydrology. Science, 351(6274), 699-703. https://doi.org/10.1126/science.aad8386

Reed, A. J., Mann, M. E., Emanuel, K. A., Lin, N., Horton, B. P., Kemp, A. C., \& Donnelly, J. P. (2015). Increased threat of tropical cyclones and coastal flooding to New York City during the anthropogenic era. Proceedings of the National Academy of Sciences, 112(41), 12610-12615. https://doi.org/10.1073/pnas.1513127112

Rietbroek, R., Brunnabend, S. E., Kusche, J., Schröter, J., \& Dahle, C. (2016). Revisiting the contemporary sea-level budget on global and regional scales. Proceedings of the National Academy of Sciences, 113(6), 1504-1509. https://doi.org/10.1073/pnas.1519132113

Rignot, E., Mouginot, J., \& Scheuchl, B. (2011). Ice flow of the Antarctic ice sheet. Science, 333(6048), 1427-1430. https://doi.org/10.1126/ science. 1208336

Rignot, E., Mouginot, J., Scheuchl, B., van den Broeke, M., van Wessem, M. J., \& Morlighem, M. (2019). Four decades of Antarctic Ice Sheet mass balance from 1979-2017. Proceedings of the National Academy of Sciences, 116(4), 1095-1103. https://doi.org/10.1073/ pnas. 1812883116

Ritz, C., Edwards, T. L., Durand, G., Payne, A. J., Peyaud, V., \& Hindmarsh, R. C. (2015). Potential sea-level rise from Antarctic ice-sheet instability constrained by observations. Nature, 528(7580), 115. https://doi.org/10.1038/nature16147

Robel, A. A., Seroussi, H., \& Roe, G. H. (2019). Marine ice sheet instability amplifies and skews uncertainty in projections of future sea-level rise. Proceedings of the National Academy of Sciences, 116, (30), 14887-14892. https://doi.org/10.1073/pnas.1904822116

Rodell, M., Velicogna, I., \& Famiglietti, J. S. (2009). Satellite-based estimates of groundwater depletion in India. Nature, 460(7258), 999. https://doi.org/10.1038/nature08238

Roemmich, D., Church, J., Gilson, J., Monselesan, D., Sutton, P., \& Wijffels, S. (2015). Unabated planetary warming and its ocean structure since 2006. Nature Climate Change, 5(3), 240. https://doi.org/10.1038/nclimate2513

Rounce, D. R., King, O., McCarthy, M., Shean, D. E., \& Salerno, F. (2018). Quantifying debris thickness of debris-covered glaciers in the Everest Region of Nepal through inversion of a subdebris melt model. Journal of Geophysical Research: Earth Surface, 123, 1094-1115. https://doi.org/10.1029/2017jf004395 
Royston, S., Watson, C. S., Legrésy, B., King, M. A., Church, J. A., \& Bos, M. S. (2018). Sea-level trend uncertainty with Pacific climatic variability and temporally-correlated noise. Journal of Geophysical Research: Oceans, 123, 1978-1993. https://doi.org/10.1002/ $2017 \mathrm{jc} 013655$

Santamaría-Gómez, A., Gravelle, M., Dangendorf, S., Marcos, M., Spada, G., \& Wöppelmann, G. (2017). Uncertainty of the 20th century sea-level rise due to vertical land motion errors. Earth and Planetary Science Letters, 473, 24-32. https://doi.org/10.1016/j. epsl.2017.05.038

Santamaría-Gómez, A., Gravelle, M., \& Wöppelmann, G. (2014). Long-term vertical land motion from double-differenced tide gauge and satellite altimetry data. Journal of Geodesy, 88(3), 207-222. https://doi.org/10.1007/s00190-013-0677-5

Scanlon, B. R., Zhang, Z., Save, H., Sun, A. Y., Schmied, H. M., van Beek, L. P., et al. (2018). Global models underestimate large decadal declining and rising water storage trends relative to GRACE satellite data. Proceedings of the National Academy of Sciences, 115(6), E1080-E1089. https://doi.org/10.1073/pnas.1704665115

Scherler, D., Wulf, H., \& Gorelick, N. (2018). Global assessment of supraglacial debris-cover extents. Geophysical Research Letters, 45, 11,798-11,805. https://doi.org/10.1029/2018gl080158

Schindelegger, M., Green, J. A. M., Wilmes, S.-. B., \& Haigh, I. D. (2018). Can we model the effect of observed sea-level rise on tides? Journal of Geophysical Research: Oceans, 123, 4593-4609. https://doi.org/10.1029/2018jc013959

Schlegel, N. J., Larour, E., Seroussi, H., Morlighem, M., \& Box, J. E. (2015). Ice discharge uncertainties in Northeast Greenland from boundary conditions and climate forcing of an ice flow model. Journal of Geophysical Research: Earth Surface, 120, 29-54. https://doi org/10.1002/2014jf003359

Schlegel, N. J., Seroussi, H., Schodlok, M. P., Larour, E. Y., Boening, C., Limonadi, D., et al. (2018). Exploration of Antarctic Ice Sheet 100-year contribution to sea-level rise and associated model uncertainties using the ISSM framework. The Cryosphere, 12(11), 3511-3534. https://doi.org/10.5194/tc-12-3511-2018

Schloesser, F., Friedrich, T., Timmermann, A., DeConto, R. M., \& Pollard, D. (2019). Antarctic iceberg impacts on future Southern Hemisphere climate. Nature Climate Change, 9(9), 672-677. https://doi.org/10.1038/s41558-019-0546-1

Schodlok, M. P., Menemenlis, D., Rignot, E., \& Studinger, M. (2012). Sensitivity of the ice-shelf/ocean system to the sub-ice-shelf cavity shape measured by NASA IceBridge in Pine Island Glacier, West Antarctica. Annals of Glaciology, 53(60), 156-162. https://doi.org/ 10.3189/2012aog60a073

Schroeder, D. M., Seroussi, H., Chu, W., \& Young, D. A. (2016). Adaptively constraining radar attenuation and temperature across the Thwaites Glacier catchment using bed echoes. Journal of Glaciology, 62(236), 1075-1082. https://doi.org/10.1017/jog.2016.100

Seroussi, H., \& Morlighem, M. (2018). Representation of basal melting at the grounding line in ice flow models. The Cryosphere, 12(10), 3085-3096. https://doi.org/10.5194/tc-12-3085-2018

Seroussi, H., Morlighem, M., Larour, E., Rignot, E., \& Khazendar, A. (2014). Hydrostatic grounding line parameterization in ice sheet models. The Cryosphere, 8(6), 2075-2087. https://doi.org/10.5194/tc-8-2075-2014

Seroussi, H., Nakayama, Y., Larour, E., Menemenlis, D., Morlighem, M., Rignot, E., \& Khazendar, A. (2017). Continued retreat of Thwaites Glacier, West Antarctica, controlled by bed topography and ocean circulation. Geophysical Research Letters, 44, 6191-6199. https://doi. org/10.1002/2017gl072910

Shamsudduha, M., Taylor, R. G., \& Longuevergne, L. (2012). Monitoring groundwater storage changes in the highly seasonal humid tropics: Validation of GRACE measurements in the Bengal Basin. Water Resources Research, 48, W02508. https://doi.org/10.1029/ 2011wr010993

Shepherd, A., Ivins, E., Rignot, E., Smith, B., Van Den Broeke, M., Velicogna, I., et al. (2018). Mass balance of the Antarctic Ice Sheet from 1992 to 2017. Nature, 558, 219-222. https://doi.org/10.1038/s41586-018-0179-y

Shimada, S., \& Bock, Y. (1992). Crustal deformation measurements in central Japan determined by a Global Positioning System fixed-point network. Journal of Geophysical Research, 97(B9), 12,437-12,455. https://doi.org/10.1029/92jb00809

Shirzaei, M., \& Bürgmann, R. (2012). Topography correlated atmospheric delay correction in radar interferometry using wavelet transforms. Geophysical Research Letters, 39, L01305. https://doi.org/10.1029/2011gl049971

Shirzaei, M., \& Bürgmann, R. (2018). Global climate change and local land subsidence exacerbate inundation risk to the San Francisco Bay Area. Science Advances, 4(3), eaap9234. https://doi.org/10.1126/sciadv.aap9234

Shirzaei, M., Bürgmann, R., Foster, J., Walter, T. R., \& Brooks, B. A. (2013). Aseismic deformation across the Hilina fault system, Hawaii, revealed by wavelet analysis of InSAR and GPS time series. Earth and Planetary Science Letters, 376, 12-19. https://doi.org/10.1016/j. epsl.2013.06.011

Simms, A. R., Ivins, E. R., DeWitt, R., Kouremenos, P., \& Miller, L. (2012). Timing of the most recent Neoglacial advance and retreat in the South Shetland Islands, Antarctica Peninsula, Insights from raised beaches evidence and Holocene uplift rates. Quaternary Science Reviews, 47, 41-55. https://doi.org/10.1016/j.quascirev.2012.05.013

Slangen, A. B. A., Adloff, F., Jevrejeva, S., Leclercq, P. W., Marzeion, B., Wada, Y., \& Winkelmann, R. (2017). A review of recent updates of sea-level projections at global and regional scales. In Integrative Study of the Mean Sea level and Its Components (pp. 395-416). New York, NY, USA: Springer. https://doi.org/10.1007/978-3-319-56490-6_17

Slangen, A. B. A., Carson, M., Katsman, C. A., Van de Wal, R. S. W., Köhl, A., Vermeersen, L. L. A., \& Stammer, D. (2014). Projecting twenty-first century regional sea-level changes. Climatic Change, 124(1-2), 317-332. https://doi.org/10.1007/s10584-014-1080-9

Slangen, A. B. A., Katsman, C. A., Van de Wal, R. S. W., Vermeersen, L. L. A., \& Riva, R. E. M. (2012). Towards regional projections of twenty-first century sea-level change based on IPCC SRES scenarios. Climate Dynamics, 38(5-6), 1191-1209. https://doi.org/10.1007/ s00382-011-1057-6

Smith, B., Fricker., H. A., Holschuh, N., Gardner, A. S., Adusumilli, S., Brunt, K. M., (2019). Land ice height-retrieval algorithm for NASA's ICESat-2 photon-counting laser altimeter. Remote Sensing of Environment, 233, 1-17. https://doi.org/10.1016/j.rse.2019.111352

Smith, W. H. F., \& Sandwell, D. T. (1997). Global sea floor topography from satellite altimetry and ship depth soundings. Science, 277, (5334), 1956-1962. https://doi.org/10.1126/science.277.5334.1956

Smith-Konter, B. R., Thornton, G. M., \& Sandwell, D. T. (2014). Vertical crustal displacement due to interseismic deformation along the San Andreas fault: Constraints from tide gauges. Geophysical Research Letters, 41, 3793-3801. https://doi.org/10.1002/2014gl060091

Spada, G., \& Galassi, G. (2016). Spectral analysis of sea level during the altimetry era, and evidence for GIA and glacial melting fingerprints. Global and Planetary Change, 143, 34-49. https://doi.org/10.1016/j.gloplacha.2016.05.006

Sriver, R. L., Lempert, R. J., Wikman-Svahn, P., \& Keller, K. (2018). Characterizing uncertain sea-level rise projections to support investment decisions. PLoS ONE, 13(2), e0190641. https://doi.org/10.1371/journal.pone.0190641

Stammer, D., Cazenave, A., Ponte, R. M., \& Tamisiea, M. E. (2013). Causes for contemporary regional sea-level changes. Annual Review of Marine Science, 5, 21-46. https://doi.org/10.1146/annurev-marine-121211-172406 
Stammer, D., Ray, R. D., Andersen, O. B., Arbic, B. K., Bosch, W., Carrère, L., et al. (2014). Accuracy assessment of global barotropic ocean tide models. Reviews of Geophysics, 52, 243-282. https://doi.org/10.1002/2014rg000450

Stephens, S. A., \& Ramsay, D. L. (2014). Extreme cyclone wave climate in the Southwest Pacific Ocean: Influence of the El Niño Southern Oscillation and projected climate change. Global and Planetary Change, 123, 13-26. https://doi.org/10.1016/j.gloplacha.2014.10.002

Strassberg, G., Scanlon, B. R., \& Rodell, M. (2007). Comparison of seasonal terrestrial water storage variations from GRACE with groundwater-level measurements from the High Plains Aquifer (USA). Geophysical Research Letters, 34, L14402. https://doi.org/ $10.1029 / 2007 \mathrm{gl030139}$

Suanez, S., Cancouët, R., Floc'h, F., BlAntarctic Ice Sheete, E., Ardhuin, F., Filipot, J. F., et al. (2015). Observations and predictions of wave runup, extreme water levels, and medium-term dune erosion during storm conditions. Journal of Marine Science and Engineering, 3(3), 674-698. https://doi.org/10.3390/jmse3030674

Sutherland, D. A., Jackson, R. H., Kienholz, C., Amundson, J. M., Dryer, W. P., Duncan, D., et al. (2019). Direct observations of submarine melt and subsurface geometry at a tidewater glacier. Science, 365, (6451), 369-374. https://doi.org/10.1126/science.aax3528

Suzuki, T., \& Ishii, M. (2011). Regional distribution of sea-level changes resulting from enhanced greenhouse warming in the Model for Interdisciplinary Research on Climate version 3.2. Geophysical Research Letters, 38, L02601. https://doi.org/10.1029/2010gl045693

Sweet, W. V., Kopp, R. E., Weaver, C. P., Obeysekera, J., Horton, R. M., Thieler, E. R., \& Zervas, C. (2017). Global and regional sea-level rise scenarios for the United States, Tech. Rep. NOS CO-OPS 083. Silver Spring, MD: National Oceanic and Atmospheric Administration.

Sweet, W. V., \& Park, J. (2014). From the extreme to the mean: Acceleration and tipping points of coastal inundation from sea-level rise. Earth's Future, 2, 579-600. https://doi.org/10.1002/2014ef000272

Sweet, W. W. V., Dusek, G., Obeysekera, J. T. B., \& Marra, J. J. (2018). Patterns and projections of high tide flooding along the US coastline using a common impact threshold, Technical Report NOS CO-OPS 086. Silver Spring, MD: National Oceanic and Atmospheric Administration.

Talke, S. A., Orton, P., \& Jay, D. A. (2014). Increasing storm tides in New York harbor, 1844-2013. Geophysical Research Letters, 41, 3149-3155. https://doi.org/10.1002/2014gl059574

Tamisiea, M. E., Mitrovica, J. X., \& Davis, J. L. (2007). GRACE gravity data constrain ancient ice geometries and continental dynamics over Laurentia. Science, 316(5826), 881-883. https://doi.org/10.1126/science.1137157

Teatini, P., Tosi, L., \& Strozzi, T. (2011). Quantitative evidence that compaction of Holocene sediments drives the present land subsidence of the Po Delta, Italy. Journal of Geophysical Research, 116, B08407. https://doi.org/10.1029/2010JB008122

Thompson, P. R., Hamlington, B. D., Landerer, F. W., \& Adhikari, S. (2016). Are long tide gauge records in the wrong place to measure global mean sea-level rise? Geophysical Research Letters, 43, 10,403-10,411. https://doi.org/10.1002/2016gl070552

Thompson, P. R., Merrifield, M. A., Wells, J. R., \& Chang, C. M. (2014). Wind-driven coastal sea-level variability in the northeast Pacific. Journal of Climate, 27(12), 4733-4751. https://doi.org/10.1175/jcli-d-13-00225.1

Tiwari, V. M., Wahr, J., \& Swenson, S. (2009). Dwindling groundwater resources in northern India, from satellite gravity observations. Geophysical Research Letters, 36, L18401. https://doi.org/10.1029/2009gl039401

Todd, J., Christoffersen, P., Zwinger, T., Råback, P., Chauché, N., Benn, D., et al. (2018). A full-Stokes 3-D calving model applied to a large Greenlandic glacier. Journal of Geophysical Research: Earth Surface, 123, 410-432. https://doi.org/10.1002/2017jf004349

Tosi, N., Sabadini, R., Marotta, A. M., \& Vermeersen, L. L. A. (2005). Simultaneous inversion for the Earth's mantle viscosity and ice mass imbalance in Antarctica and Greenland. Journal of Geophysical Research, 110, B07402. https://doi.org/10.1029/2004jb003236

Trossman, D. S., \& Tyler, R. H. (2019). Predictability of ocean heat content from electrical conductance. Journal of Geophysical Research: Oceans, 124, 667-679. https://doi.org/10.1029/2018jc014740

Turki, I., Laignel, B., Chevalier, L., Costa, S., \& Massei, N. (2015). On the investigation of the sea-level variability in coastal zones using SWOT satellite mission: Example of the eastern English channel (Western France). IEEE Journal of Selected Topics in Applied Earth Observations and Remote Sensing, 8(4), 1564-1569. https://doi.org/10.1109/jstars.2015.2419693

Tyler, R. H., Boyer, T. P., Minami, T., Zweng, M. M., \& Reagan, J. R. (2017). Electrical conductivity of the global ocean. Earth, Planets and Space, 69(1), 156. https://doi.org/10.1186/s40623-017-0739-7

Tymofyeyeva, E., \& Fialko, Y. (2015). Mitigation of atmospheric phase delays in InSAR data, with application to the eastern California shear zone. Journal of Geophysical Research: Solid Earth, 120, 5952-5963. https://doi.org/10.1002/2015JB011886

Van den Broeke, M. R., Enderlin, E. M., Howat, I. M., Kuipers Munneke, P., Noël, B. P., Jan Van De Berg, W., et al. (2016). On the recent contribution of the Greenland ice sheet to sea-level change. The Cryosphere, 10(5), 1933-1946. https://doi.org/10.5194/tc-101933-2016

van der Spek, A. J. (2018). The development of the tidal basins in the Dutch Wadden Sea until 2100: The impact of accelerated sea-level rise and subsidence on their sediment budget-a synthesis. Netherlands Journal of Geosciences, 97(3), 71-78. https://doi.org/10.1017/ njg.2018.10

Van Wessem, J. M., Jan Van De Berg, W., Noël, B. P., Van Meijgaard, E., Amory, C., Birnbaum, G., et al. (2018). Modelling the climate and surface mass balance of polar ice sheets using RACMO2: Part 2: Antarctica (1979-2016). The Cryosphere, 12(4), 1479-1498. https://doi. org/10.5194/tc-12-1479-2018

Vaughan, D. G., Corr, H. F., Bindschadler, R. A., Dutrieux, P., Gudmundsson, G. H., Jenkins, A., \& Wingham, D. J. (2012). Subglacial melt channels and fracture in the floating part of Pine Island Glacier, Antarctica. Journal of Geophysical Research, 117, F03012. https://doi. org/10.1029/2012jf002360

Velicogna, I., \& Wahr, J. (2006). Measurements of time-variable gravity show mass loss in Antarctica. Science, 311(5768), $1754-1756$. https://doi.org/10.1126/science.1123785

Vermeersen, B. L., Slangen, A. B., Gerkema, T., Baart, F., Cohen, K. M., Dangendorf, S., et al. (2018). Sea-level change in the Dutch Wadden Sea. Netherlands Journal of Geosciences, 97(3), 79-127. https://doi.org/10.1017/njg.2018.7

Vieli, G. M. L., Hindmarsh, R. C. A., \& Siegert, M. J. (2007). Three-dimensional flow influences on radar layer stratigraphy. Annals of Glaciology, 46, 22-28. https://doi.org/10.3189/172756407782871729

Vitousek, S., Barnard, P. L., Fletcher, C. H., Frazer, N., Erikson, L., \& Storlazzi, C. D. (2017). Doubling of coastal flooding frequency within decades due to sea-level rise. Scientific Reports, 7(1), 1399. https://doi.org/10.1038/s41598-017-01362-7

Vizcaíno, M., Lipscomb, W. H., Sacks, W. J., van Angelen, J. H., Wouters, B., \& van den Broeke, M. R. (2013). Greenland surface mass balance as simulated by the Community Earth System Model. Part I: Model evaluation and 1850-2005 results. Journal of Climate, 26(20), 7793-7812. https://doi.org/10.1175/jcli-d-12-00615.1

Volkov, D. L., Lee, S. K., Landerer, F. W., \& Lumpkin, R. (2017). Decade-long deep-ocean warming detected in the subtropical South Pacific. Geophysical Research Letters, 44, 927-936. https://doi.org/10.1002/2016gl071661 
Voss, K. A., Famiglietti, J. S., Lo, M., De Linage, C., Rodell, M., \& Swenson, S. C. (2013). Groundwater depletion in the Middle East from GRACE with implications for transboundary water management in the TiGreenland Ice Sheet-Euphrates-Western Iran region. Water Resources Research, 49, 904-914. https://doi.org/10.1002/wrcr.20078

Vousdoukas, M. I., Mentaschi, L., Voukouvalas, E., Verlaan, M., Jevrejeva, S., Jackson, L. P., \& Feyen, L. (2018). Global probabilistic projections of extreme sea levels show intensification of coastal flood hazard. Nature Communications, 9(1), 2360. https://doi.org/ 10.1038/s41467-018-04692-w

Wada, Y., Lo, M. H., Yeh, P. J. F., Reager, J. T., Famiglietti, J. S., Wu, R. J., \& Tseng, Y. H. (2016). Fate of water pumped from underground and contributions to sea-level rise. Nature Climate Change, 6(8), 777. https://doi.org/10.1038/nclimate3001

Wada, Y., Reager, J. T., Chao, B. F., Wang, J., Lo, M. H., Song, C., et al. (2017). Recent changes in land water storage and its contribution to sea-level variations. Surveys in Geophysics, 38(1), 131-152. https://doi.org/10.1007/s10712-016-9399-6

Wada, Y., van Beek, L. P. H., Sperna Weiland, F. C., Chao, B. F., Wu, Y.-H., \& Bierkens, M. F. P. (2012). Past and future contribution of global groundwater depletion to sea-level rise. Geophysical Research Letters, 39, L09402. https://doi.org/10.1029/2012gl051230

Wahl, T., Brown, S., Haigh, I., \& Nilsen, J. (2018). Coastal sea levels, impacts, and adaptation. Basel, Switzerland:MDPI Publishing.

Wahr, J., DaZhong H., \& Trupin A. (1995). Predictions of vertical uplift caused by changing polar ice volumes on a viscoelastic Earth. Geophysical Research Letters, 22, (8), 977-980. https://doi.org/10.1029/94gl02840

Wahr, J., Wingham, D., \& Bentley, C. (2000). A method of combining ICESat and GRACE satellite data to constrain Antarctic mass balance. Journal of Geophysical Research, 105, (B7), 16279-16294. https://doi.org/10.1029/2000JB900113

Wahl, T., \& Chambers, D. P. (2015). Evidence for multidecadal variability in US extreme sea-level records. Journal of Geophysical Research: Oceans, 120, 1527-1544. https://doi.org/10.1002/2014jc010443

Wahl, T., Haigh, I. D., Nicholls, R. J., Arns, A., Dangendorf, S., Hinkel, J., \& Slangen, A. B. (2017). Understanding extreme sea levels for broad-scale coastal impact and adaptation analysis. Nature Communications, 8, 16075. https://doi.org/10.1038/ncomms16075

Wahr, J. M., \& Davis, J. L. (2002). Geodetic constraints on glacial isostatic adjustment. Ice Sheets, Sea Level and the Dynamic Earth, Geodynamic Series, 29, 3-32. https://doi.org/10.1029/gd029p0003

Wang, Z. B., Elias, E. P., van der Spek, A. J., \& Lodder, Q. J. (2018). Sediment budget and morphological development of the Dutch Wadden Sea: Impact of accelerated sea-level rise and subsidence until 2100. Netherlands Journal of Geosciences, 97(3), 183-214. https://doi.org/ 10.1017/njg.2018.8

Wiese, D. N., Yuan, D. N., Boening, C., Landerer, F. W., \& Watkins, M. M. (2017). JPL GRACE Mascon Ocean, ice, and hydrology equivalent water height RL05M. 1 CRI filtered, Ver. 2, PO. DAAC, CA, USA. Dataset provided by Wiese in Nov/Dec.

Willis, M. J., Melkonian, A. K., Pritchard, M. E., \& Rivera, A. (2012). Ice loss from the Southern Patagonian ice field, South America, between 2000 and 2012. Geophysical Research Letters, 39, L17501. https://doi.org/10.1029/2012gl053136

Wilmes, S. B., Green, J. M., Gomez, N., Rippeth, T. P., \& Lau, H. (2017). Global tidal impacts of large-scale ice sheet collapses. Journal of Geophysical Research: Oceans, 122, 8354-8370. https://doi.org/10.1002/2017jc013109

Wingham, D. J., Siegert, M. J., Shepherd, A., \& Muir, A. S. (2006). Rapid discharge connects Antarctic subglacial lakes. Nature, 440(7087), 1033. https://doi.org/10.1038/nature04660

Wise, A., Hughes, C. W., \& Polton, J. A. (2018). Bathymetric influence on the coastal sea-level response to ocean gyres at western boundaries. Journal of Physical Oceanography, 48(12), 2949-2964. https://doi.org/10.1175/jpo-d-18-0007.1

Wise, A., Hughes, C. W., Polton, J. A., \& Huthnance, J. M. (2020). Leaky slope waves and sea level: Unusual consequences of the beta-effect along western boundaries with bottom topography and dissipation. Journal of Climate. https://doi.org/10.1175/JPO-D-19-0084.1

Woodworth, P. L. (2010). A survey of recent changes in the main components of the ocean tide. Continental Shelf Research, 30(15), 1680-1691. https://doi.org/10.1016/j.csr.2010.07.002

Woodworth, P. L., Hunter, J. R., Marcos, M., Caldwell, P., Menéndez, M., \& Haigh, I. (2017). Towards a global higher-frequency sea-level dataset. Geoscience Data Journal, 3(2), 50-59. https://doi.org/10.1002/gdj3.42

Woodworth, P. L., Melet, A., Marcos, M., Ray, R. D., Wöppelmann, G., Sasaki, Y. N., et al. (2019). Forcing factors affecting sea-level changes at the coast. Surveys in Geophysics, 1-47. https://doi.org/10.1007/s10712-019-09531-1

Wöppelmann, G., \& Marcos, M. (2016). Vertical land motion as a key to understanding sea-level change and variability. Reviews of Geophysics, 54, 64-92. https://doi.org/10.1002/2015rg000502

Wouters, B., Bamber, J. L., Van den Broeke, M. R., Lenaerts, J. T. M., \& Sasgen, I. (2013). Limits in detecting acceleration of ice sheet mass loss due to climate variability. Nature Geoscience, 6(8), 613. https://doi.org/10.1038/ngeo1874

Wouters, B., Gardner, A. S., \& Moholdt, G. (2019). Global glacier mass loss during the GRACE satellite mission (2002-2016). In Frontiers in Earth Science, 7(96), 1-11. https://www.frontiersin.org/article/10.3389/feart.2019.00096

Wouters, B., Martin-Español, A., Helm, V., Flament, T., Van Wessem, J. M., Ligtenberg, S. R., et al. (2015). Dynamic thinning of glaciers on the Southern Antarctic Peninsula. Science, 348(6237), 899-903. https://doi.org/10.1126/science.aaa5727

Wu, P., \& van der Wal, W. (2003). Postglacial sealevels on a spherical, self-gravitating viscoelastic earth: Effects of lateral viscosity variations in the upper mantle on the inference of viscosity contrasts in the lower mantle. Earth and Planetary Science Letters, 211, (1-2), 57-68. https://doi.org/10.1016/s0012-821x(03)00199-7

Yoder, C. F., Williams, J. G., Dickey, J. O., Schutz, B. E., Eanes, R. J., \& Tapley, B. D. (1983). Secular variation of Earth's gravitational harmonic $J_{2}$ coefficient from Lageos and nontidal acceleration of Earth rotation. Nature, 303, (5920), 757-762. https://doi.org/10.1038/ $303757 \mathrm{a} 0$

Yu, C., Li, Z., Penna, N. T., \& Crippa, P. (2018). Generic atmospheric correction model for Interferometric Synthetic Aperture Radar observations. Journal of Geophysical Research: Solid Earth, 123, 9202-9222. https://doi.org/10.1029/2017jb015305

Yu, C., Penna, N. T., \& Li, Z. (2017). Generation of real-time mode high-resolution water vapor fields from GPS observations. Geophysical Research: Atmospheres, 122, 2008-2025. https://doi.org/10.1002/2016jd025753

Zanna, L., Khatiwala, S., Gregory, J. M., Ison, J., \& Heimbach, P. (2019). Global reconstruction of historical ocean heat storage and transport. Proceedings of the National Academy of Sciences, 116(4), 1126-1131. https://doi.org/10.1073/pnas.1808838115

Zarfl, C., Lumsdon, A. E., Berlekamp, J., Tydecks, L., \& Tockner, K. (2015). A global boom in hydropower dam construction. Aquatic Sciences, 77, (1), 161-170. https://doi.org/10.1007/s00027-014-0377-0

Zebker, H. A., \& Villasenor, J. (1992). Decorrelation in interferometric radar echoes. IEEE Transactions on Geoscience and Remote Sensing, 30(5), 950-959. https://doi.org/10.1109/36.175330

Zekollari, H., Huss, M., \& Farinotti, D. (2019). Modelling the future evolution of glaciers in the European Alps under the EURO-CORDEX RCM ensemble. The Cryosphere, 13(4), 1125-1146. https://doi.org/10.5194/tc-13-1125-2019

Zemp, M., Huss, M., Thibert, E., Eckert, N., McNabb, R., Huber, J., et al. (2019). Global glacier mass changes and their contributions to sea-level rise from 1961 to 2016. Nature, 568(7752), 382. https://doi.org/10.1038/s41586-019-1071-0 
Zhao, C., King, M. A., Watson, C. S., Barletta, V. R., Bordoni, A., Dell, M., \& Whitehouse, P. L. (2017). Rapid ice unloading in the Fleming Glacier region, southern Antarctic Peninsula, and its effect on bedrock uplift rates. Earth and Planetary Science Letters, 473, 164-176. https://doi.org/10.1016/j.epsl.2017.06.002

Zhao, Z., Alford, M. H., Girton, J. B., Rainville, L., \& Simmons, H. L. (2016). Global observations of open-ocean mode-1 M2 internal tides. Journal of Physical Oceanography, 46(6), 1657-1684. https://doi.org/10.1175/jpo-d-15-0105.1 